THE

HUMAN STDE

PIA N TS

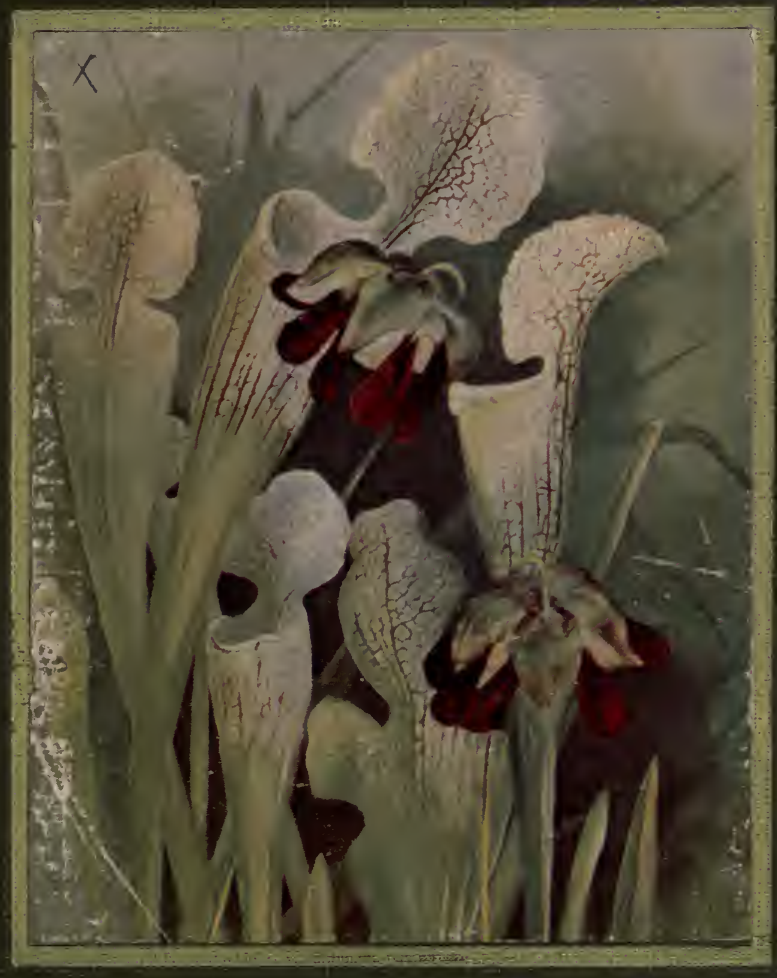

\title{
ROYAL DIXON
}




\section{LIBRARY UNIVERSATY OF}

CMLIFOHNIAA SAN DIEGO 
Bogena Hratle

1920 



\section{THE HUMAN SIDE OF PLANTS}






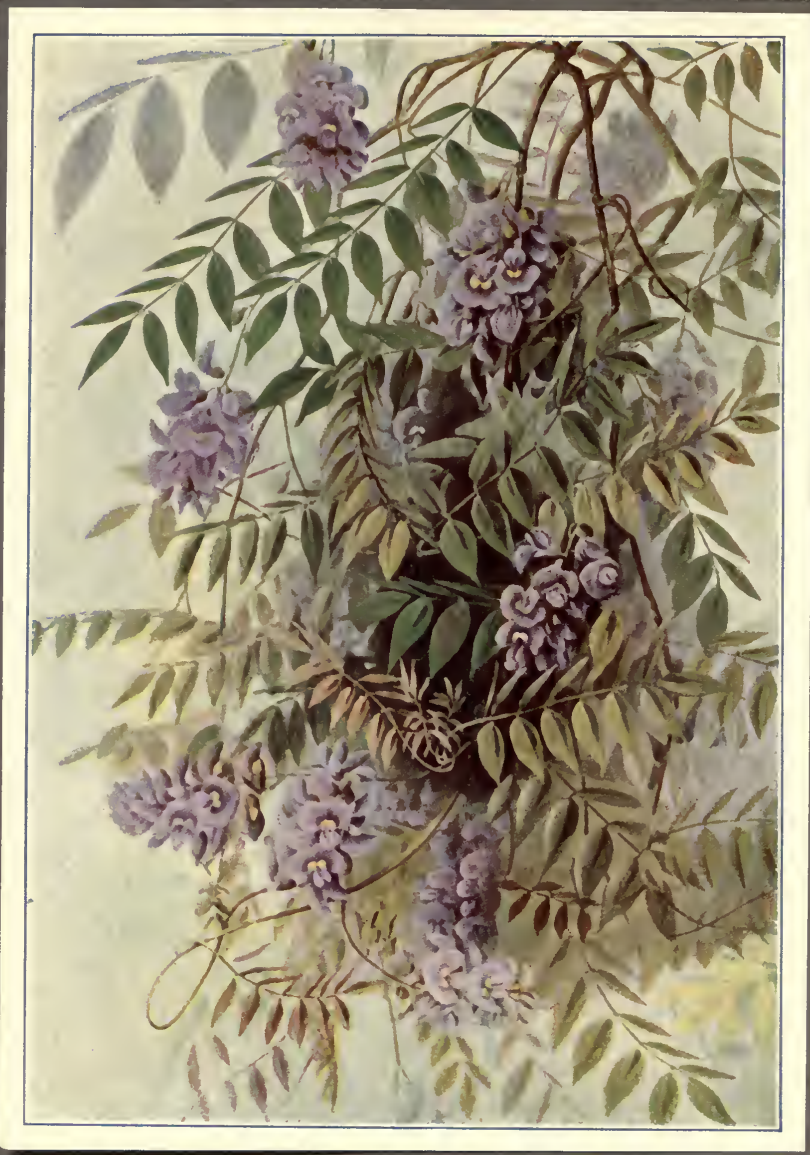

AMERICAN WISTARI1. Kraunhia frutescens.

A sturdy athlete, one of the most hardy and most beautiful of all climbing plant: 


\section{THE \\ HUMAN SIDE \\ OF PLANTS}

BY

ROYAL DIXON

WITH FOUR ILLUSTRATIONS IN COLORS AND

THIRTY-TWO IN BLACK-AND-WHITE

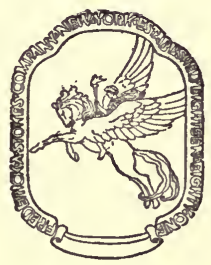

NEW YORK

FREDERICK A. STOKES COMPANY PUBLISHERS 
Copyright, 1914, by

Frederick A. Stokes Company

All rights reserved, including that of translation into forcign languages

SECOND PRINTING

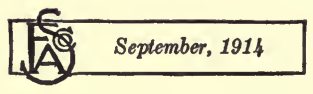


To

AGNES AND LOLITA 



\section{NOTE}

The author desires to acknowledge his sincere indebtedness to Mr. Raymond Comstock for encouragement in the pursuance of this work, for critical readings, and for suggestions and advice, which have contributed materially to the production of this book. 



\section{FOREWORD}

F recent years there has come into man's life a new joy. This joy is the acquaintanceship with plants. ( Nature has long been ready to reveal her secrets, but only to those prepared to hear and see.) Gradually a new understanding has arisen between Nature and mankind, and as a result we obtain from such a revelation a joy undreamed of a few years ago.

In no department of the sciences has this awakening to truth been more in evidence than in botany. (Plants no longer are lifeless things labelled and grouped under ponderous Latin titles; they are highly developed organisms, which see, hear, taste, feel, walk, swim, run, fly, jump, skip, hop, roll, tumble, set traps and catch fish; decorate themselves that they may attract attention; powder their faces; imitate birds, animals, serpents, stones; play hide and seek; blossom underground; protect their children, and send them forth into the world prepared to care for themselves-indeed, do all those things which we ourselves do! $\int_{\text {ix }}^{W e}$ know now that plants 


\section{$x$ THE HUMAN SIDE OF PLANTS}

have even minds and souls, with which to think and to worship. )

We live to-day in an age of discoveries, of awakenings. Things, seen for centuries, are suddenly dawning on our realisation as facts, as truths. In every branch of science, of philosophy, of religion, is this so. And as each truth is newly realised and is added to the store of understood things, we find in the new understanding some kinship, some relationship to other truths. All truths point to a universal truth; all the divisions of nature are closely akin to one another.

In this day of discoveries there have been revelations in every branch of science and many inventions based on these revelations. But the greatest of revelations are those which pertain to the origin, purpose, and extent of life. TThrough all ages the quest of thinking men has been for an understanding of the origin and purpose of life; in our present day, above all questions of national or civic action, the question of the whence and the whither of our living holds the greatest interest among all classes of thinking people. And it is in its fund of truths pertaining to life, that Nature offers its strongest invitation to the interest of mankind.

In admitting the kinship between all the divisions of nature, we acknowledge a relationship between 
all forms of life. The plant, the animal, the bird, the fish, the human, since each is a member of a living species, and related through one nature, perhaps a single origin, must in the habits and actions of its living portray characteristics of similarity to every other species. It is for us to devote ourselves to the study of these other forms of life, in order to find out the truths which each may hold, the secret keys to the great mysteries of life.

The Human Side of Plants is the unlocking of the doors which have barred us from the mysteries of the plant kingdom. It is an entrance into the private life of plantkind. What secrets we may learn from the plant nature and habits and characteristics to help us in understanding the origin, purpose, and extent of life, can be found only by an intimate acquaintance with the inner life of the plants.

Only through many years of close association can one hope faithfully to describe the life and character of a race of people. And only through close application, conscientious research, a patience that comes only from love, can one understand the nature and habits of plants.

With The Human Side of Plants, I am blazing a trail. In many of the plant acts described, I am declaring heretofore unpublished truths, 


\section{xii THE HUMAN SIDE OF PLANTS}

truths which must unquestionably meet the censure of the book-taught botanists of the old schools, but which will quite as unquestionably meet the entire approval of those naturalist-botanists of the more modern type, who accept no result without its cause and who study life for the love of it, with no prescribed limitations of fact or possibility. To many of these, the truths, here set forth for the first time, come as a verification of their own theories.

In the preparation of this work I have repeatedly been questioned by interested friends, educated men and women, who wondered at many of the simplest statements of the characteristics and actions of the different plants. "Is this true?" has been the surprised inquiry. "Do plants really set traps and catch fish?" "Do they actually keep servants and employ standing armies?" "Isn't that merely a figure?"

It is amazing - the average child reaches manhood or womanhood with a surprising lack of knowledge concerning the simplest natural objects about it. Educated in the great colleges of the country, having laboured through "courses" in botany, the student too often comes forth with a vague impression that "chlorophyll is green stuff," "plants are fertilised by bees," and with decided likes and dislikes for plants in the edible form of 
table vegetables. The fact that in studying plants he has been studying living organisms, beings which think and feel, which have souls and worship, fellow members of a great universe, has never entered his thought. The appalling thing in this regarding of plants as mere things is not the apparent slight to the plant, but the real loss to the student in his lack of appreciation of the wonder and beauty around him.

It is therefore with the earnest hope that in this work the young student, the future man or woman, as well as the adult, may find a revelation of the living things about him, that I have prepared THE Human Side of Plants.

If in its entertainment it encourages a little greater interest in the other species of life, a little greater love for the plant species, one of the most beautiful of all forms of life, and a little greater respect for the Divine Source of all Life, it will have accomplished its purpose.

Royal Dixon.

New YoRk, May, 1914. 


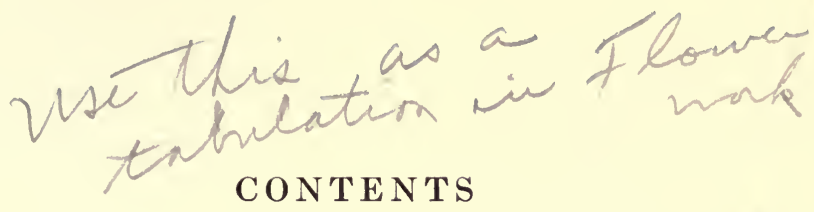

CHAPTER

PAGE

I Plants that Walk . . . . . . 1

II Plants that Eat Insects . . . . 11

III Plants that Fish . . . . . . 21

IV Plants that Mimic . • • . . . 26

V Plants that Defend Themselves - 34

VI Plants that Keep a Standing Army and Navy; Plants that Empioy an Aerial Squadron; Plants that Keep Servants and Live Stock • 52

VII Plants that Rob, Plunder, and MurDER • . . . . . . . . . 60

VIII Plants that Are Athletes . . 72

IX Plants that Ride on Animals • 90

X Plants that Predict the Weather; Compass Plants; Dame Nature's

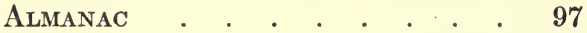

XI Plants that Tell the Time of Day;

Plants that Keep a Diary . . . 104

XII Plants that Build Airships . • 111

XIII Plants that Build Islands • • 118

XIV Plants that Produce Lights; Plants THAT SEE • • • • . • • • . 128

XV Plants that Carry Life-Insurance 133

XVI Plants that Kidnap • • • • . 143

XVII Plants that Entertain . . . . 151 
xvi

\section{CONTENTS}

CHAPTER PAGE

XVIII Plants that Go to Sleep . . . . 157

XIX Plants that Hide Their Blossoms and Their Frutt . . . . . . 165

XX The Courtship and Marriage of Pllants . . . . . . . . . 170

XXI Plant-animals and Animal-plants . 179 XXII The Mentality and Spirituality of Plants . • • • • • • • • 185 


\section{ILLUSTRATIONS}

AMERICAN WISTARIA. Kraunhia frutescens . . . Frontispiece

FACING

PAGE

TRAILING ARBUTUS. Epigeia repens • • • • • $\quad 8$

TULIPS. Tulip picotee . • • • • • • • • • • • 9

PITCHER-PLAN'T. Sarracenia purpurea . • • • . 18

MOCCASIN-FLOWER. Cypripedium acaule . . . . $\quad$ • $\quad$. 19

MOTH ORCHID. Cypripedium . . . . . • . . . 28

YELLOW LADY'S SLIPPER. Cypripedium pubescens 29

TAR-FLOWER. Bejaria racemosa . . . . . . . . 42

CACTI . . . . . . . . . . . ., 50

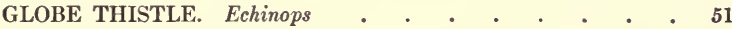

WATER-LILIES. Nymphæa odorata . • • • • • . 68

INDIAN PIPE (Monotropa uniflora) and BEECH-DROPS (Mono-

tropa Hypopitys) .

JIMSON-WEED. Datura Stramonium . . . . . . $\quad 80$

WITCH-HAZEL. Hamamelis Virginica . . . . . . $\quad$ • 81

YELLOW JASSAMINE. Gelsemium sempervirens - • - . 88

UNICORN-PLANT. Martynia proboscidea . • • • . 96

SUNFLOWER. Helianthus . . . • • • • • 97

DAY LILY. Hemerocallis fulva . . • • • • . . 106

MOONFLOWER. Ipomaa Bona-nox . • • • . . . 107

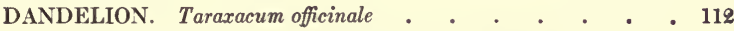

GOLDENROD (Solidago) and MILKWEED (Asclepias) . . . 113

MARIGOLD. Tagetes erecta . . • • • • • • • • 128

NASTURTIUMS. Tropæolum nanum . • • • • • • • . 129

DAFFODILS. Narcissus telamonius plenus . . • • . . 138

xvii 
xviii ILLUSTRATIONS

PAGE

MOUNTAIN LAUREL. Kalmia latifolia . . • • • . 139

JACK-IN-THE-PULPIT. Arisøma triphyllum . • • • . 148

STARRY CAMPION. Silene stellata . . • • • • . 149

YUCCA. Yucca filamentosa . . . . . . . . . 154

MARSH-MARIGOLD. Calthra palustris . . . . . . 155

NIGHT-BLOOMING CEREUS. Cereus grandiflorus • • 160

JMSON-WEED. Datura Stramonium . . . • . . . 161

PEANUT or GROUNDNUT. Arachis hypogaa . . . . . 166

COMMON THISTLE. Cirsium lanceolatum . • • • . 167

FLAME AZALEA. Azalea lutea . . . • • • • 174

WOOD SORREL. Oxalis acctosella. • . • • • • 190

TRUMPET VINE. Tecoma radicans . . . . . . . 191 


\section{THE HUMAN SIDE OF PLANTS}

In all places, then, and in all seasons, Flowers expand their light and soul-like wings, Teaching us, by most persuasive reasons, How akin they are to human things.

-Longfellow. 



\section{THE HUMAN SIDE OF PLANTS}

I

PLANTS THAT WALK

In Malabar, or Deccan, spreads her arms, Branching so broad and long, that in the ground The bended twigs take root, and daughters grow About the mother-tree, a pillared shade, High over-arched, and echoing walks between. -Milton, on the Indian Fig (Paradise Lost).

merE are in plants many different kinds of
movement, besides the folding together of the leaflets, the drooping of the stems, the opening of the flowers, the shooting forth of certain seeds, the propelling motion of airship varieties, and the regular climbing habits of other species. Plants migrate as do birds or animals: that is, they travel and establish themselves without the aid of man in other territory than their former homes.

The wind is the most common agent in the scat- 


\section{THE HUMAN SIDE OF PLANTS}

tering of plants; especially is this true in mountainous countries, and near the sea, where the valleys and cliffs are swept by the wind, and the tiny seeds are often carried together with dust and sand for great distances. The wind plants the sides and crevices of the most lofty mountains, some plant seeds being driven even across the Mediterranean Sea or the Atlantic Ocean, since they are frequently lighter than sand. The extreme minuteness of some seeds is almost incomprehensible to the human imagination. For example, a single capsule of a South African orchid has been found to contain the tremendous number of one and three-quarter millions of tiny seeds!

We know that the ashes of volcanoes have been driven by the wind more than a thousand miles; in 1845 an eruption took place in Hecla, Iceland, and some of the ashes were blown to Ireland and England. It is not strange, then, that often after a terrible wind-storm mountain-sides and high cliffs are covered with new flowers in nature's own way of planting.

But there are some plants which travel by actually walking!

Currant bushes, wishing to multiply, do not wait for such a slow process as dropping their seeds to the ground and letting them, little by little, sprout 
and develop into new bushes. They are much too impatient for that; they know a quicker way. They walk; and as they walk, they develop new plants. The mother bush selects a good healthy branch; she reaches out and carefully bends it down to the earth; and down into the ground she sends little roots from the branch. The roots collect the nourishment, send it up into the branch, and, lo, the branch itself is soon a flourishing currant bush, ready to take another step in its walk by sending out a branch of its own to grow rootlets and develop into still another bush.

In the same way, white clover, strawberries, sweet potatoes, Wandering Jew, and many forms of grasses, walk by planting others like themselves./ Some of them send out "runners" which walk along the ground, like the common verbena, trailing arbutus, numerous grasses, and trailing lycopodiums; and each new plant or off shoot, as soon as it begins to grow, sends out its own runners. Thus new plants are continually made.

Skilled gardeners and farmers thoroughly understand how to cover certain parts of potato vines, for instance, with layers of soil, and later, by cutting the vine near where it has taken root, to multiply the number of plants.

Some plants have "suckers"-branches that 


\section{THE HUMAN SIDE OF PLANTS}

spring from their parent stem underground and later appear as separate plants; and eventually the little connecting link or thread may be entirely destroyed. It is in this way- "by root," as we saythat raspberry bushes increase or spread out.

Many grasses spread in the same way, and in all directions; some have joints from which upright stems arise, and which send down into the earth roots of their own, interlacing and binding the soil and thus spreading very rapidly. Such grasses grow several feet in a few months. The quackgrass is a typical example of a fast walker and for this reason is greatly feared by farmers.

Tulips are noted for their ability to walk. If planted in dark, shady places, where it is cold and damp, they will deliberately walk away from the dark place into a more desirable part of the garden. They usually move into the sun. The bulb that was planted does not itself actually move, but its substance is transferred little by little, and only the outer wrapping of brown tissue is left. The bulb sends out a delicate shoot that runs horizontally below the ground until it has reached a distance of several inches. Then, near its point, a swelling begins to take the shape of a tulip bulb, which grows larger and larger as the food-material of the old bulb is brought into it. This is done by 
the little shoot. If the particular sunny or light spot toward which the tulip is walking should unexpectedly be shaded, it will immediately begin to move in another direction.

Club-mosses are noted travellers. And the common club-moss has acquired for itself many names as well as possessing many lands. It flourishes from the arctic to the tropical regions of both hemispheres; thriving equally well under all conditions. It is used extensively for Christmas decorations, and, were it not for its manner of rooting and walking, it would run a risk of becoming extinct; but the smallest bit of the plant will immediately take root and begin to spread out.

Some plants have an entirely different way of walking; in fact, hopping or jumping would best describe it, as there is no real connection between the mother plant and the new little ones. A good example is the life-plant, of Bermuda, a tall, sturdy, weed-like plant with its fatty large leaves deeply scalloped. It drops one of these leaves on to the ground; and a few days later four or five, sometimes as many as ten, new plants are growing beside the mother: one plant has sprung from every scallop, thus forming themselves over the earth in the exact shape of the leaf, like happy children in preparing to play certain games. 


\section{THE HUMAN SIDE OF PLANTS.}

This plant is scientifically known as Bryophyllum calycinum. When the little plants have become sturdy enough to develop roots, the mother-leaf gradually shrivels up and drops away, leaving her little ones, like orphaned children, to care for themselves.

The curious and beautiful walking-ferns, perhaps the most difficult of all ferns to raise in the ordinary garden, are too rare to be found at many florists. They are very fastidious and demand the shade, drainage, and air-to suit their particular tastes-that only the larger gardens and greenhouses can afford. They will not live "in captivity," except in the shadiest nook or corner, and then they produce a sickly growth, with yellowish-green fronds, which, after tapering to a dainty tip, like tiny threads, drop to the ground and take root as new plants. What actually takes place is this: A bud forms at the extreme tip of the frond and develops a cluster of small fronds and roots, while swinging in the air. The increasing weight of the young plant, especially when wet with rain or dew, causes the long frond to bend its tip to the earth, and there take root as a new plant, according to its characteristic and very curious way of walking. Thus the ferns spread and travel, each little frond linked to its neighbour by the delicate 


\section{PLANTS THAT WALK}

thread-like chain that holds the colony together like little children clasping hands.

A more striking example of a plant that walks and takes possession of large surfaces, both of land and water, is the Marsilia. It belongs to a very interesting family of plants, which are fern allies, and bear neither flowers nor real seeds. In appearance it closely resembles the four-leafed clover. The Marsilia has a long, thread-like rootstalk, and sends out little creepers, which crawl along and then shoot up into leaves. Many botanists claim that it grows only in water; but really it flourishes best when growing with the least amount of water. When it grows underneath the water the leaves peep out just above the surface.

Another well-known walking plant is the wintergreen. It has nodding flowers and shiny red berries. It is an evergreen, and the stem usually creeps below the ground, sending down clusters of roots and sprouting up new stems, from which at first green leaves spring, then later little branches of delicate flowers, and lastly wonderful red berries. The leaves and berries are good to eat, and are often used, especially the former, in flavouring candies and in medicine. Wintergreen has many different names in various parts of the country. It has no season, but blossoms and bears fruit from 


\section{THE HUMAN SIDE OF PLAN'TS}

spring until October. It grows in various kinds of soil, but prefers dark, shady places, with plenty of moisture. What a striking picture it makes, when found in large patches, with its dark green leaves, its red fruit, and its dainty flowers all showing at once!

The lovely trailing arbutus, which is sometimes known as ground laurel, or Mayflower, is another walking plant. Its delicate white or pink flowers are usually hidden beneath its leaves away under the snow, for it is among the very earliest flowers of spring to bloom.

\section{"Pure and perfect, sweet Arbutus Twines her rosy-tinted wreath."}

Like many of our rarest birds, which have become extinct because of their wonderful beauty, the trailing arbutus not only threatens to become extinct, but is already unknown in many localities where it once flourished. This is a tragedy indeed, and lovers of this early spring beauty should not only refrain from gathering too many of these flowers, but should encourage others to leave them to grow. Florists often send young boys out to collect the flowers, and they thoughtlessly pull up the entire plant.

Its method of progress is like that of other walk- 


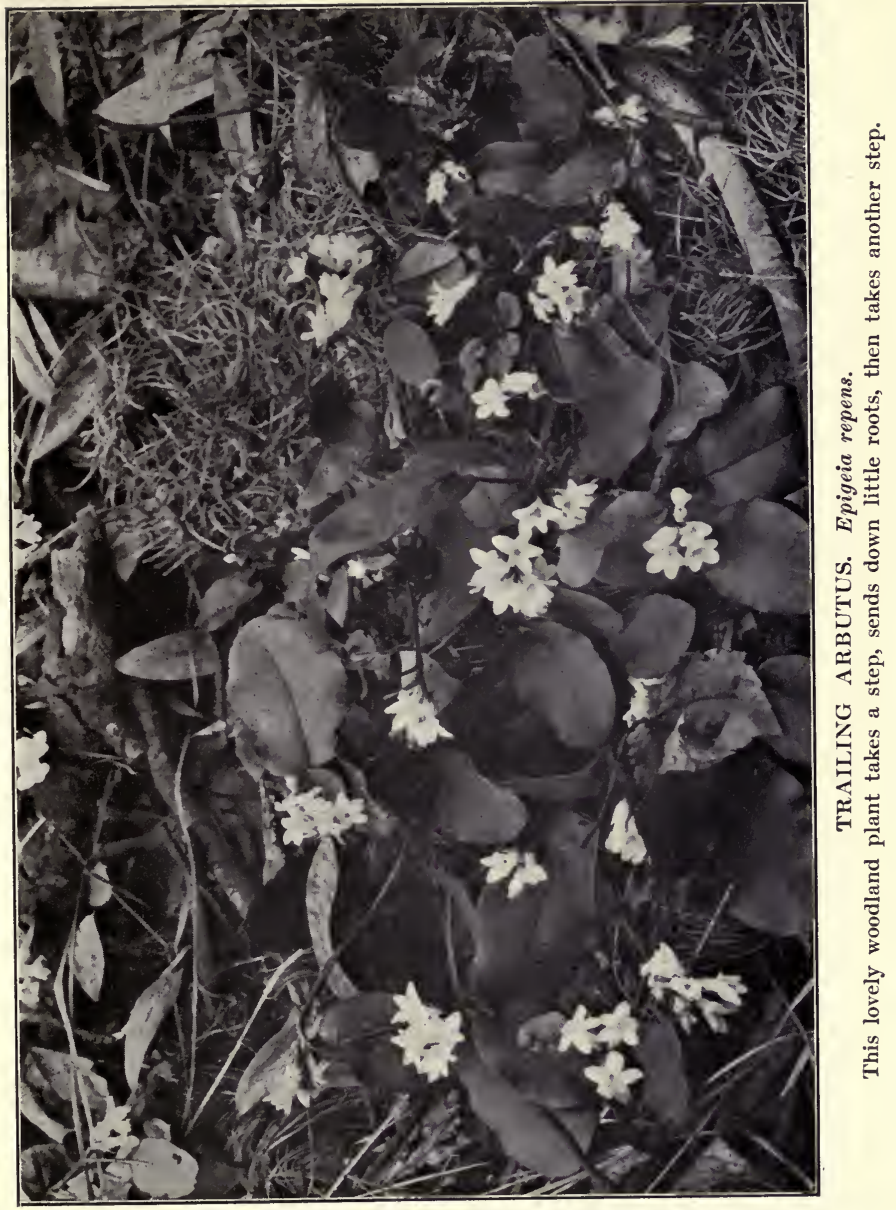




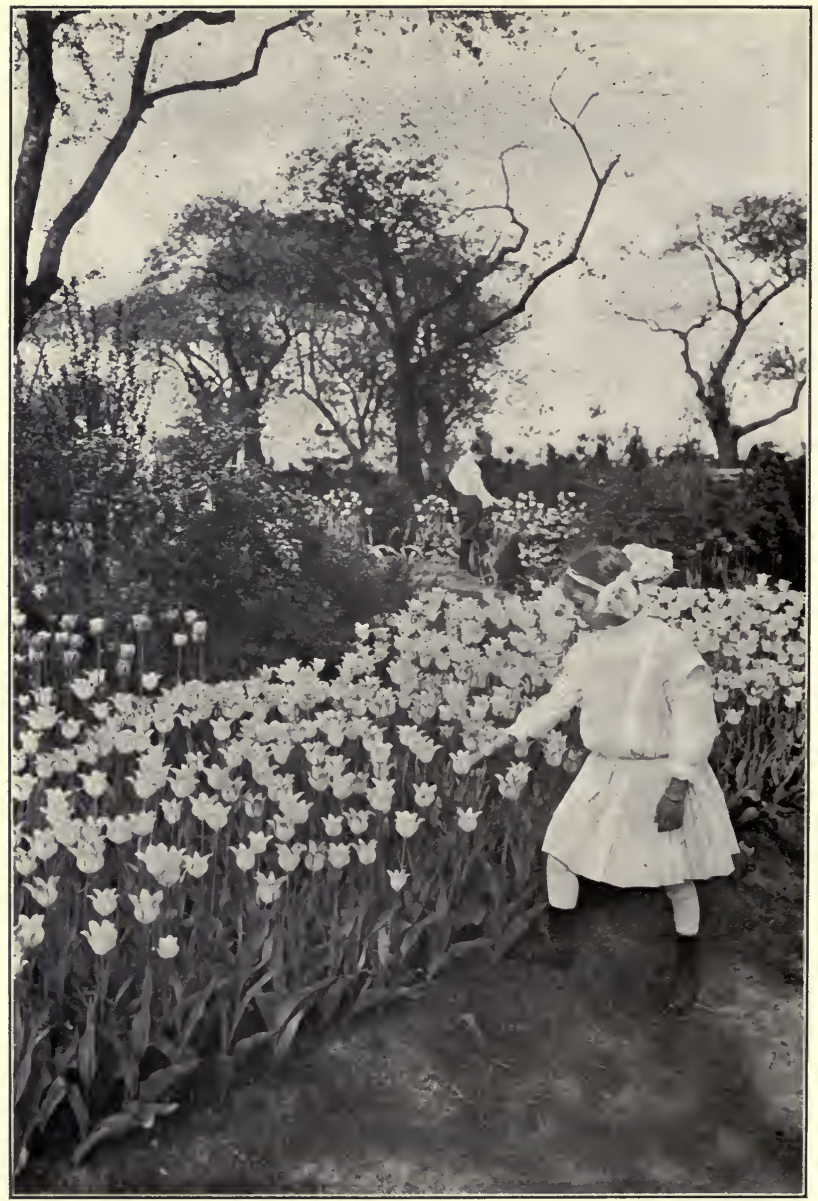

TULIPS. Tulip picotee.

Tulips love the sunshine, They will deliberately walk away from a dark place. 
ing plants. It takes a step, sends down little roots, then another step, until it is satisfied. Whittier claims that the Mayflower was the first flower to greet the Pilgrims at Plymouth Rock when they landed; and that it greatly encouraged them with its beauty and courageous habits.

Another good walker is the sensitive mimosa, one of those curious sensitive plants which show their objection to being handled by quickly closing their leaflets, folding them together in pairs, when touched. The sensitiveness of the plant is so extreme that if one leaf is touched roughly the neighbouring leaves will close in sympathy, and the whole stem droop. They remain in this withered-looking condition until they believe the danger to be past, when they unfold their leaflets and brighten up again.

A dainty and much-loved walker is the twinflower. Its bell-shaped blossoms grow in pairs, with their drooping heads suspended from an upright stem. They are a delicate crimson-pink, and there is about them a delightful fragrance that is like the odour of almond blossoms.' The plant loves the mossy ground of deep woods, where it walks over a large area.

But among the great walkers must be mentioned the many grasses and sedges which thrive along 


\section{THE HUMAN SIDE OF PLANTS}

the sandy shores and vast marsh lands. There are, too, the familiar fresh-water sedges; but the most striking examples are to be found in the sandloving grasses near the sea. The marram grass, seaside oats, and St. Augustine grass, are examples of this type, which walk with their thin, creeping roots over the surface of the sands. So rapid is their progress and so widely diverse are their meanderings, that they form great and very useful nets, which hold down the drifting sands.

Men living along the shores of the sea appreciate the value of these walkers as allies in maintaining the physiographical outlines of the coast and in protecting their cultivated lands from injury by drifting sands. As a result, they plant seeds of the various binding grasses, knowing well that, once started on the sides of a dune, the walkers will rapidly cover its surface and bind down as permanent and immutable prisoners its migratory grains of sand. 


\section{II}

PLANTS THAT EAT INSECTS

"So sensitive,
It catcheth each rover that doth touch its leaves."

DLANTS set traps, catch, and eat flies, bees, I butterflies, gnats, ants, fish, and even large moths!

There are a variety of animal foods which are needed to satisfy the various tastes of plants; for the same menu cannot satisfy all kinds of plants, any more than one food can suit the palates of all human beings. Plants have their likes and dislikes in food, just as people have their preferences. Most of the insect-eating plants love marshy lowlands, and in such localities they cannot get from the earth the necessary amount of nitrogen and sulphur, which all plants require. As a result they are forced to resort to carnivorous habits, in order to obtain the requisite nourishment. They set traps, catch their prey, kill and eat it, and extract from the bodies of these insects the food required. The carnivorous plants have many ingenious 


\section{THE HUMAN SIDE OF PLANTS}

methods of securing their prey. Some actually set traps into which the unsuspecting traveller is lured; some so place their bait as to entice the prey gradually into their innermost dungeons, from which no live insect ever returns; some set their traps under water, for they like fish; others diabolically imitate the mother-fish's mouth, so that the frightened little minnows, in time of danger, may rush into it for safety.

One of the most remarkable of the insect-eating plants, really marvellous in the humanness of its cunning, is Venus's fly-trap, which has its home in the swamps of North Carolina. The leaf-stalks are divided into two parts; the lower part performs the work of a real leaf, while the upper part is engaged in trapping insects. This upper partthe leaf-trap-consists of two halves, edged with a long row of teeth and covered with a network of fine "nerves." Like all expert trappers, the plant is so alert and sensitive that the slightest touch on one of the nerve-hairs causes the leaf to close instantly, like a mouse-trap; and when the leaf is closed it forms a trap from which no marauder can escape.

The plant spreads its leaves out along the ground, each leaf tipped with a tempting bit of honey. The unsuspecting insect comes eagerly to 


\section{PLANTS THAT EAT INSECTS 13}

drink of the nectar; he steps on one of the sensitive nerve-hairs; the leaf-trap snaps shut-and the plant devours its meat at leisure, first soaking it with a sticky digestive fluid. When the insect has been entirely absorbed, the leaf opens again and carefully resets its trap.

The sundew is a striking plant of this meat-eating family. What a harmless looking, dainty thing it is! All grouped together in little colonies, it grows close to the ground. Its leaves, which are arranged in small rosettes, are covered with scarlet tentacles, and at the tip of each of these tentacles, or hairs, is a minute drop of honey, which glistens like dew with the sun on it: hence the plant's name, sundew. From the centre of the rosette-leaves, a slender stalk shoots up several inches into the air, and is covered at the upper end with delicate, pinkish-violet flowers. The result of this beautiful arrangement of colours and forms is a seductively inviting trap to the unwary.

However, it is not to the eye of the insect, but to his stomach, that the most direct appeal is made. The insects are attracted not by the flowers but by the glistening, dew-like hairs; and as soon as a poor wanderer tries to drink the drops of honey so temptingly displayed, he becomes hopelessly entangled among the sticky-ended tentacles. The 


\section{THE HUMAN SIDE OF PLANTS}

more he tries to free himself, the more hopelessly he becomes bound. Finally his struggles are ended, and the flood-like hairs, having poured out enough fluid to digest him, innocently assume their normal condition and await the next prey.

The sundew is very widely distributed throughout the world, there being more than one hundred species. They are found in the marshy regions of North and South America, in India, China, and all of Europe. Their general habits are very much the same everywhere.

Interesting experiments may be made with the sundew by placing it near a sunny window in a saucer or pot filled with damp sand. Here, if properly fed and cared for, it will live and flourish for a considerable length of time. Its favourite food seems to be a particle of beef, or a fly, or a bit of boiled egg. If this is placed near the outer border of the leaves, the glands which touch the food will immediately begin to send out their liquid to secure it. As a result, the food-particle is soon rolled and pulled to the centre of the leaf, where the short hairs are located; long and short tentacles then pour out their fluid to digest it. When the meal is finished, they assume their original positions.

Chief among the insect-decoyers are the siren- 


\section{PLANTS THAT EAT INSECTS 15}

mannered pitcher-plants. These are divided into several species, which are widely distributed throughout the world. An exceedingly curious and striking species is the American pitcher-plant, or, as it is sometimes called, side-saddle plant, known to botanists as Sarracenia purpurea. The pitchers are closed at the bottom, and the inside contains a considerable quantity of an attractive fluid, while the upper part of the pitcher is covered with a halfclosed lid. It is the leaves of the plant which form the pitchers; and they are charmingly coloured, being usually of a dark greenish-purple.

The plant has a very ingenious manner of capturing its prey. The inner walls are covered with a number of hairs, which point downward. On these hairs is the sweet, sticky fluid, that lures the insect to its death. The fly or bee enters this palatial death chamber very cautiously. There is no apparent danger, only a veritable palace of sweets! But lo, once within, there is no escape! The hairs on the walls, which have bent easily for his entrance, project to prevent him from crawling out; while the top is so shaped that he cannot fly vertically. As a result he soon tumbles, bewildered, into the putrefying liquid below, and there miserably drowns.

These murderous plants are often filled with 


\section{THE HUMAN SIDE OF PLANTS}

hundreds of dead and decaying insects, especially ants. As a result the plant gives forth an extremely off ensive odour.

An interesting cousin to the purpurea is the Sarracenia variolaris, in which the pitchers are formed in much the same way as in the purpurea. The top, however, does not stand up as an open lid, but droops over the mouth like a cap. These delicately formed pitchers are at first hermetically sealed, and when the lid at last rises they are nearly half filled with a colourless fluid, which tends to dry up rather than increase as the plant grows older. The liquid at the bottom of the pitcher is not sweet, but possesses toxic qualities which aid in decomposing the prey.

Sarracenia Drummondi, one of the bog plants with carnivorous habits, has developed its leaves to such a high degree of perfection that marvellous trumpet-like pitchers are the result! These pitchers are simple enough when viewed from the outside; but their insides are skillfully lined with curved hooks and hairs which in some species are sufficiently powerful to hold small birds that have been lured into the death-traps. The Drummondi grows in the pine barrens of America, especially in Georgia, Florida, and the Carolinas. Its brilliant purple blossoms, which droop, umbrella- 


\section{PLANTS THAT EAT INSECTS 17.}

fashion, on the stem, and its dainty lace-veined pitchers with their shield-like wings, make the plant one of the most attractive of the insect-eaters.

But while these blood-thirsty plants cunningly deceive and destroy many insects in order to feast upon them, there are at least two species of insect that seek their homes and food from the plants. One of these is a small moth, marked with greyishblack and yellow across its wings and back. These tiny moths move around in the pitchers as though in a miniature palace! And it is a palace to them; for, from the time the parent moth first lays her eggs at the mouth of the pitcher, until the young moth eats her way through the bottom of the leaf, it is a veritable paradise of luxuries. The small egg hatches into a larva which weaves for itself a thin silken shawl. The larva feeds on the plant until the walls cave in, when the gaudy moth sails forth into the world.

The other species of insect which finds a genial haven in these pitcher-plants is a fly, which in its larval state feeds on the decaying bodies of the putrid insects at the bottom of the pitcher, and finally bores through the leaf and drops to the ground, from which it later arises a full-fledged fly.

These two species of insect evidently do not suit 


\section{THE HUMAN SIDE OF PLANTS}

the taste of the voracious pitcher-plant; thus they not only escape being eaten, but they get revenge for the injury done to others!

Of all lands where the pitcher-plants thrive, the island of Borneo seems to be their paradise. They are as plentiful in the mountains there as the wild morning-glory is in America; small shrubs, trees, and bushes are covered with their variegated and variously shaped pitchers. Some look like small trumpets, others are like dwarfed gourds; but all seem diabolically planned death-traps!

Of all plants which have the insect-eating habit, perhaps none is more unusual than the Darlingtonia. It is unquestionably the most beautiful of the pitcher family, yet it is the least known. This may be accounted for by the fact that it grows high in the mountains, and is exceedingly rare. In the swampy marsh-lands of Mount Shasta, California, it is often found, but usually only by botanists. It closely resembles the Sarracenia; the pitchers are curved, and the cap extends into a long cover overhanging the mouth. Its leaves look like the tail of a beautiful bird.

Many of the orchids-such, for instance, as the dainty moccasin-flower, loved of the mountain children-so shape their flowers that wingless insects decoyed into them have small chance of escape. 


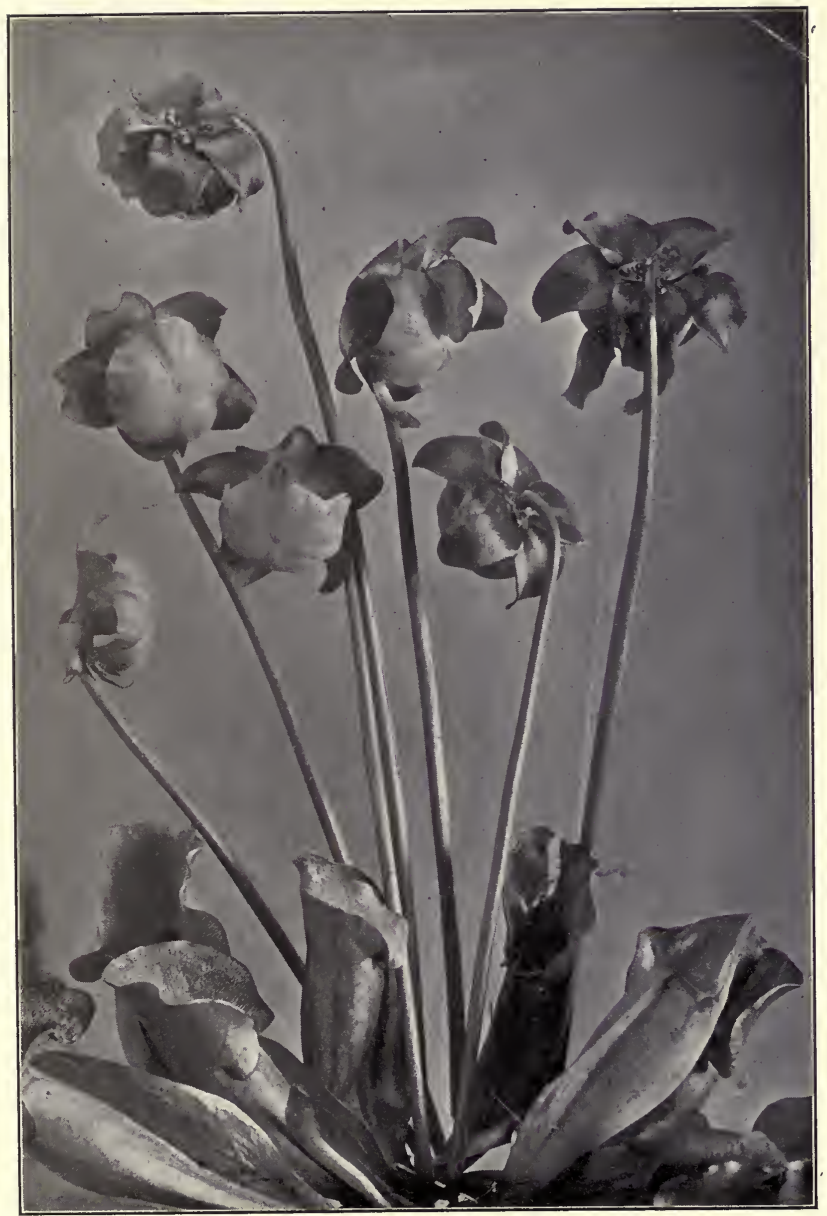

PITCHER-PLANT. Sarracenia purpurea.

The pitcher-shaped leaves form traps to catch the insects which this plant devours. 


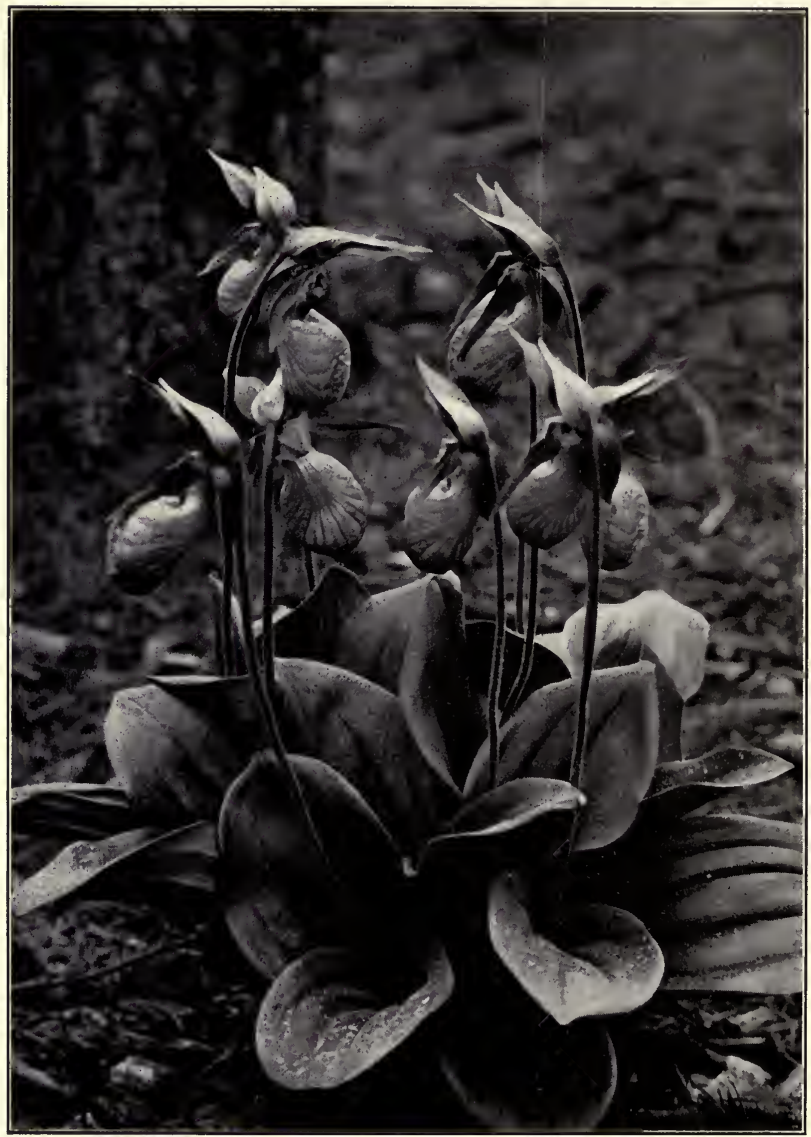

MOCCASIN-FLOWER. Cypripedium acaule.

Insects have small chance to escape when once caught within these blossoms. 
These orchids are not considered insect eaters, but they undoubtedly draw a certain amount of nour ishment from the decayed bodies of their insectprey.

The habits of the carnivorous plants are such that it is not unreasonable to suppose that it is merely a matter of proportion that determines the size of the prey such plants would be able to kill and eat; that, in truth, were the plant of sufficiently great development, it might even become strong enough to kill a man. In fact, more than one traveller reports that such a plant does exist, and is the terror of the natives where it grows.

This man-eating plant grows in Nicaragua, near Lake Nicaragua, and is always found in the deep swamps. The natives have rightfully named it "Devil's-snare"; and for horror it has no rival. This vampire-vine is not unlike the weeping willow denuded of its leaves, but it is of a blackish-brown colour, covered with a thick gluey resin, that aids it in binding its prey. By means of its finger-like claws it is enabled to catch small animals, and envelop them in a network of its diabolical arms. Here they are hopelessly held until the last drop of blood is drawn from their bodies by its infinitesimal sucking-mouths.

There is an insidious suggestion in the habits of 


\section{THE HUMAN SIDE OF PLANTS}

this Devil's-snare which stirs in the imaginative mind vague, unnameable dread. If this be possible with one plant already known to exist, where is the hindrance to the attainment of similar or greater power by the number of other carnivorous plants, which already show by their habits traits so cruel, so cunning, so avaricious, as to cause a shudder of horror to one observing them even in their present diminutive form.

There is another plant, a parasitical native of Sumatra, whose flower already has attained proportions that would, were it carnivorous in its habits, render it a thing to be avoided by human beings and animals for fear of their lives. This is the ponderous Arnoldi, the flower of which is described by Dr. Arnold, its discoverer, as measuring "a full yard across," the bowl for nectar being large enough to hold twelve pints, and the weight of a single blossom being about fifteen pounds. Disastrous indeed might be the results if such a giant plant were to develop, like the sundews and pitcherplants, a taste for meat! 


\section{III}

\section{PLANTS THAT FISH}

IKE certain land plants, which through generations of struggling have acquired carnivorous habits, there are certain aquatic plants which have learned to set traps and fish for their daily fare.

Plant beings, both land and water, which cannot move from their places, nor wage warfare with hoofs, daggers, or teeth, have learned the value of the nitrogenous elements to be found in decaying animal matter, and, having recognised the need, have arranged their habits of living accordingly.

There are many carnivorous sea plants, which live entirely on small forms of animal life, their prey varying in size from the tiniest animalcule to minnows and similar small fish, and in some instances to forms of animal life of decidedly more formidable dimensions.

The means of catching fish used by marine plants include an interesting array, ranging from baited 


\section{THE HUMAN SIDE OF PLANTS}

traps to "stinging" harpoon hairs, from hidden snares to electric shocks.

The bladderwort (Utricularia) is perhaps one of the most strikingly ingenious fishing plants. The bladderwort is dependent upon the water for its food-supply, for from its stock of small animal life the plant draws nourishment. The name of this plant is derived from the small bladders or fishing nets which are scattered over its leaves and stems. In some countries, generally tropical countries, the bladderwort actually grows on the sides of trees, like numerous other air-plants, maintaining its carnivorous habits and appetites, but satisfying them with insects of the land instead of aquatic animal life. But its general habitat is the water, in small lakes, ponds, and wet ditches, and there we must look if we would find it fishing for its dinner.

The bladders or sacs of the plant are apparently devised especially to entrap animal life. Little fish swim into a mouth or opening at one end of the oval bladders and the doors swing in before them allowing the fish to enter; but when they would depart, the doors will not accommodatingly open out, and the minnows find themselves prisoners. There they die and their decaying bodies are slowly fed upon by the voracious plant. 
Other forms of the bladderwort have devised different ways of luring and capturing their prey. There is a species that shapes its "nets" and very cunningly curves its leaves under the water to imitate the mouth of the mother fish. The baby fishes, when frightened from any cause, swim in for protection, their entrance stirring sensitive nerve-hairs that cause the leaves to close. On the inside of these leaves is a rough, spiky surface, which, on the closing of the walls, renders passage through them an impossibility. So the tiny fish are imprisoned and gradually devoured, giving nourishment to the plant that has betrayed them. When the plant finds its larder empty, the leaves are opened out again, to procure a new supply.

Despite its foul and decaying contents, the voracious bladderwort presents a remarkably dainty exterior, with its strange, aerial stems which are covered with marvellously beautiful white and green flowers. These flowers appear at a short distance as though, like Mohammed's coffin, they were miraculously suspended in the air. Perhaps their beauty is but an additional lure to the unwary!

An interesting "fishing plant" is one that is found on the coast of Africa, known as "trembling leaves." This plant, however, does not do the fish- 


\section{THE HUMAN SIDE OF PLAN'TS}

ing itself, but is used by the natives. They powder the leaves and mix them with sand and lime; the mixture is then scattered by divers in holes and caves where fish are plentiful. The fish become stupefied and immediately rise to the top where they are caught by the natives in small fish-nets.

There are certain kinds of fish which for purposes of safety attach their eggs to aquatic plants, and as a result the seaweed forests are covered with millions of fish-eggs and nests. The close proximity of these plants and fish results frequently in the imitation by the fish of both the appearance and the habits of the plant. An interesting example of this is the case of a strange fish which strongly resembles the sargasso, among which it lives and builds its nest. This floating nest is the repository of the fish's eggs. The young hatch in their floating cradle, which not only affords them bits of green food to eat, but acts as a hiding-place against larger fish, for, as they are so strikingly like the plant of which their nest is composed, they are easily concealed.

Perch invariably attach their nests to floating plants.

There are other fish, like the stickleback, which build their nest of "weed" and attach it to a stationary water plant, where it looks very much like 


\section{PLANTS THAT FISH}

the nest of a humming-bird depicted hanging from the branch of a small tree.

For this protection and shelter, the plants demand some return: the fish must defend them constantly from mutual enemies. In other words, the plants keep a swimming squadron! 


\section{IV}

PLANTS THAT MIMIC

HOR many years botanists have observed the
striking resemblance between certain harmless unprotected plants and others which are well armed by nature to defend themselves; not only do plants imitate each other, but frequently they imitate many kinds of poisonous insects, moths, beetles, lizards, and even rattlesnakes. Certain plants actually imitate bad odours, carrion of all kinds, obnoxious weeds, and various forms and kinds of things which they are not, from disagreeable animals to harmless pebbles. These mimetic resemblances are, in most instances, so striking as to defy all explanation, and they occur only between two species of animals or plants which are found in the same region, of which one species is thoroughly protected and the other is not. Why does nature trouble herself with all of these curious external resemblances? It is comprehended only in the light of mimicry, and under the theory that unprotected plants mimic dangerous or obnoxious 
plants, animals, and insects-or in some cases so subtly imitate the surrounding conditions as to pass unnoticed-in order to come under the protection of those better equipped for defence.

Every one knows that plants become changed according to their habitat. A tree from a tropical climate becomes a dwarf shrub in a northern climate; a desert plant often begins to drop its prickles when placed in a climate and under conditions where it no longer needs them; water-loving plants, like the mangrove tree, refuse to send out aerial roots when grown in inland places, and in some cases they actually change their form. There is no doubt that similarity of habitat produces a likeness in form. Water plants nearly invariably have long and feather-like leaves, which give the impression of floating or swaying in the water.

A plant never mimics another plant or an insect without some good reason. Usually it is to deceive the enemies common to itself and to the better-defended plant that it pretends to be. Or if it assumes the shape and form of an insect, it is that flower-destroyers may pass it by.

There are perhaps few examples of imitation in the plant world more wonderful than that found among the orchids. There is the bee orchid, with its marvellous labellum (lip or lower petal) of 


\section{THE HUMAN SIDE OF PLANTS}

satiny brown marked with a deep yellow, and its two side petals curiously like wings, the entire flower so simulating the form and colour of a bee that at a casual glance even a skilled botanist might mistake a cluster of its flowers for a number of bees on a twig!

Another near relative of the bee orchid, and equally imitative, is the fly orchid, whose peculiarly formed flowers have a tiny blue spot in the centre of each, exactly like that of certain flies. Its long and delicate side petals are like the antennæ of a moth.

Then there is the spider orchid, with huge trailing petals resembling a spider's legs when ready to jump; in its dark centre is a blackish-red spot, characteristic of a very poisonous and much feared tarantula.

Other orchids assume the shape of frogs, of lizards, snakes, birds, moths, or butterflies; and the green-man orchid is thought to represent the figure of a man.

These plants no doubt derive a protection by this form of mimicry that could hardly be improved upon. It is occasionally so marvellous and is carried out with such minute details of structure, that even a skilled botanist is often deceived. As a result, the plant flourishes unmolested because 


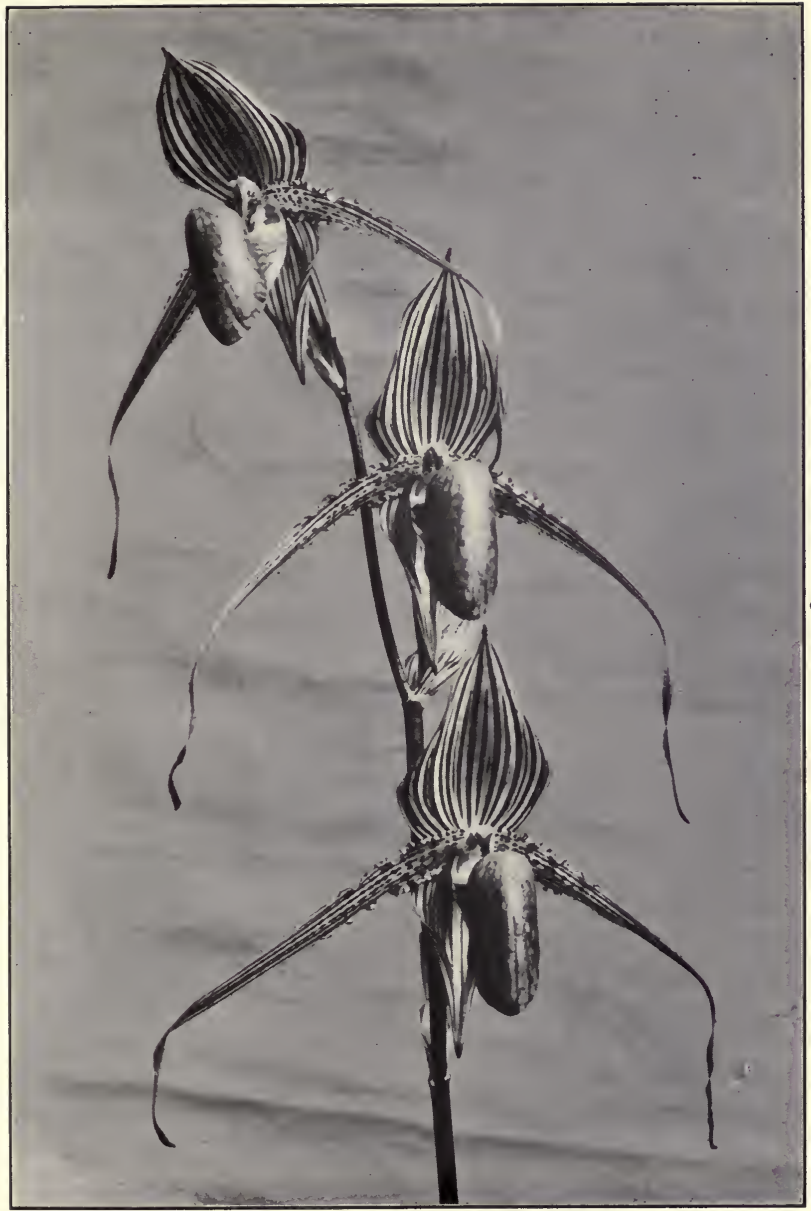

MOTH ORCHID. Cypripedium.

A cluster of these orchids might easily be mistaken for a number of moths resting on a twig. 


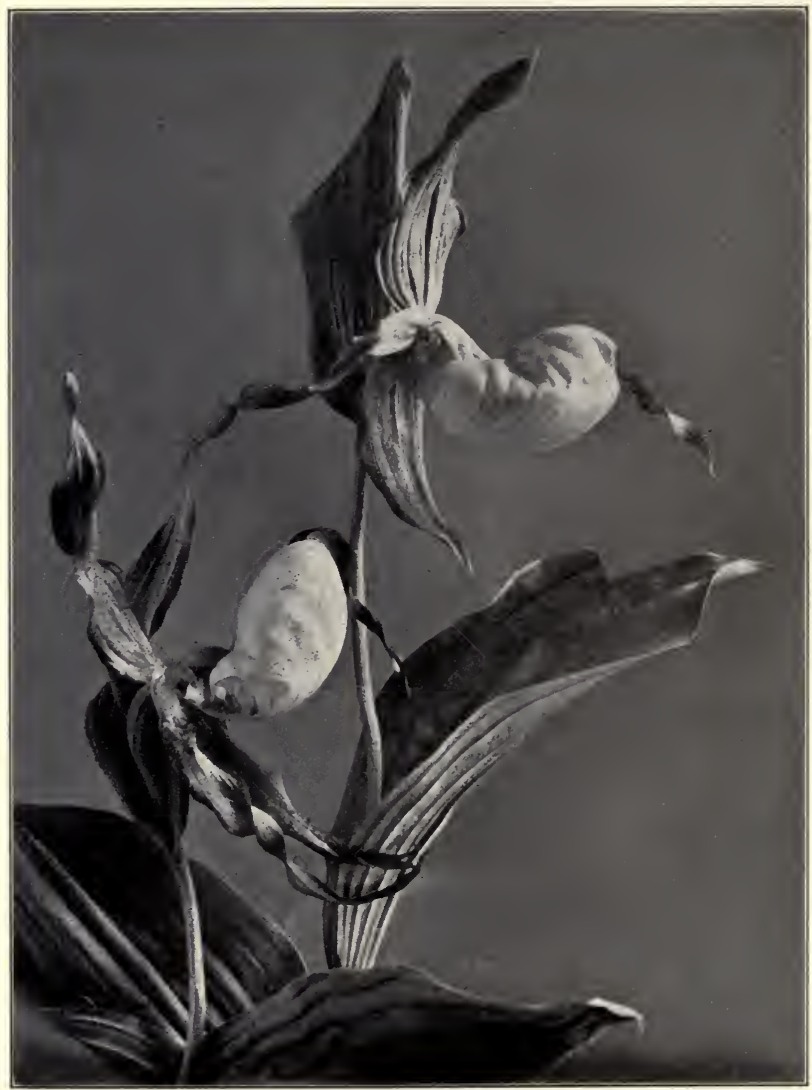

YELLOW LADY'S SLIPPER. Cypripedium pubescens.

This is not so successful in its imitation of insects as are some of the orchids. 
of the evil reputation of the insect or the plant that it mimics.

A unique case of imitation is the rattlesnake iris which grows abundantly in the western part of the United States, especially on the dry plains where cattle, horses, and sheep graze. To prevent itself from being eaten, this plant mimics, by means of its dry seeds, the noise of the rattlesnake; and not only does it mimic the rattle of the snake, but its fruits are held in small glossy black capsules not unlike the black head of certain other snakes.

There is a species of red lotus which grows in the tropics whose fruit-pods are formed like a wasp's nest; and the India-rubber plant has roots whose convolutions and contortions are like so many snakes twisting out of the earth.

If we examine the lichens we find a trumpet, a hat, and various letters. Mildews and moulds arrange themselves into cages, clubs, cups and saucers, umbrellas, knives and forks, snake-like creatures; and one kind of fungus imitates the most exquisite lace.

Strange and very animal-like plants are the Raoulias of New Zealand. They grow in compact masses on the sides of semi-barren hills, and are so strikingly like a sheep in appearance that it is not uncommon for shepherds to approach them and 


\section{THE HUMAN SIDE OF PLANTS}

actually touch them with their staffs thinking the plants an ill or lazy animal!

Perhaps one of the most unusual instances of real mimicry is found among castor-oil beans. They assume both the shape and the colour of the coccinella beetles, and so escape the attention of graminivorous birds which would be likely to peck the seeds to pieces and destroy them. They look, too, not unlike tiny pebbles.

The sea-weeds also are imitative. They mimic many earthly and human things: the broad green and red fronds are perfectly simulated ribbons; the numerous forms and colours of algæ lie marvellously close to laces, frills, threads, nets, and feathers floating in the sea. What a world of imitations under the water! Here a string of beads; there a graceful sea-fan carelessly waving at some phantom lover! Beads, necklaces, jewels all displaying their ornate loveliness to any one who will behold!

An interesting form of plant simulation is that which is found in a certain species of mistletoe. This plant is a native of Australia, and its leaves imitate so closely the leaves of the plant on which it is a parasite, that only a skilled botanist or naturalist can distinguish between the two.

A similar example, equally interesting, is that of 
a leafless parasite which in Mexico grows on a leafless cactus.

Among the desert plants, the cacti claim a large share of natural likenesses. These, as well as other succulent plants, which find it necessary to store up sweet juices for their own use during the longcontinued droughts, would be entirely destroyed by thirsty and hungry cattle and other animals were it not for their ability so to imitate their surrounding by mimicking the grey pebbles and sands as to pass unnoticed.

The ice-plant, one of the Mesembryanthemums, covers its head with a hoar-frost, for all the world like a piece of ice; but the sun does not melt it, nor.do the rains dissolve it! Other forms of the Mesembryanthemums are composed largely of succulent shoots, and so closely resemble the stones surrounding them that they pass unnoticed by hungry and thirsty animals, and are thus allowed to flourish even in the deserts of South Africa.

Almost every species of animal or insect has its imitator in the plant world: the horse's shoe is imitated by the Hippocrepis; the bull's head is represented by the Trapa bicornis. There is a species of lotus which greatly resembles the foot of a bird, including the toes. Some of the lupines have seeds strikingly like tarantulas; and the seeds of the 


\section{THE HUMAN SIDE OF PLANTS}

Dimarpholays, a vine resembling the gourd, look precisely like small dead branches or twigs. One kind of Scorpiurus produces pods that to the eye are centipedes; another species produces worms or caterpillars!

Plants simulate the odours and perfumes as well as the forms and colours of "things which they are not." Some simulate the odour of pepper, of cheese, cucumbers, roast beef, sour milk; and others, like the carrion plant, or cuckoo-pint, smell like rotten and decaying flesh; still others, like the roots of the orris, give forth a delightful perfume. The dragon arum, a native of southern Europe, arrays itself in the most gorgeous costume, whose regal splendour challenges the proudest of the floral kingdom; and, yet, as soon as the spadix appears, with its black silky dagger, the plant gives forth a terrible odour which attracts large numbers of insects, that aid in distributing its pollen.

The American skunk-cabbage is another example of a plant that attracts the attention of flies and insects by imitating the odour of decaying flesh. No doubt, owing to its early appearance in the spring, if it did not have this offensive odour it would be quite neglected by the few early insects which have ventured out before the snow disappears from the ground. 
A very different reason for mimicry is that shown by the dead-nettle. Its cousin, the stingingnettle, belongs to a poisonous family, and is well protected by "stinging hairs." Grazing animals through ages of experience have learned to give it a wide berth! The dead-nettle, on the other hand, is quite harmless; but it so closely mimics its evilfamed relative as to share in the latter's immunity! The horehound, also, shows its wisdom by mimicking the well protected stinging-nettle. This, however, seems no more astonishing than the curious resemblance certain seeds-like the maple, elm, ash, and sycamore-bear to the wings of evil-tasting moths and other insects.

A striking example of mimicry is the pebblebriar, of the Philippine Islands. Its seeds are spherical in shape, and some have flat surfaces whose colour varies from a light sandy shade to a reddish brown. They not only imitate amazingly certain pebbles, but they actually give the appearance of stratification by small lines which circle them.

Many and curious are the ways of Mother Nature for the protection of her offspring! 


\section{V}

PLANTS THAT DEFEND THEMSELVES

THE first instinct of all life-human, beast, 1 bird, or plant-is the instinct of self-protection. This is one of the greatest evidences of the kinship among all forms of life. In plant life this intuitive self-protection is very apparent: so apparent that the wonder is that so few people consider it.

Plants, like animals and human beings, have their numerous enemies, their dangers and hardships, which they must meet and overcome. And, just as with mankind and animals, those plants which are not prepared to defend themselves against their numerous foes and destroyers must eventually give up the battle to the stronger.

Every day of every season with plants the battle is waged. They must defend themselves against all the forces of nature, such as winds, heat, cold, and tides; they must defend themselves against birds, animals, and fish; and they must wage ingenious warfare among themselves-the weaker 


\section{PLANTS DEFEND THEMSELVES 35}

struggling against the stronger; the stronger mercilessly crushing the weaker. The contention among plants is bitter and frequently cruel. In addition, they must survive the ravaging onslaught of the all-destroying human kind. The extent to which they progress in overcoming these obstacles marks their success or failure in the struggle of life.

The habitat of plants largely decides their type of difficulties and dangers. Thus the air plant is immune from the pests which force the desert plant to protect itself with daggers and prickles; aquatic plants rarely are troubled with creeping, wingless insects or burrowing grubs; arctic plants, such as mosses and lichens, need no defence against moths and tropical pests; while plants like dandelions and milkweeds, which send their children out into the world by means of airships and balloons, have no fear of city congestion. So all plant life, as all animal and human life, has been wisely created, protected from certain dangers by its environment, and provided with a means of defence against those other dangers to which its environment subjects it. For none is the burden made too heavy; for all is the necessity to struggle in order to grow and live. In the plant world as in the human world there is a law of compensation. 


\section{THE HUMAN SIDE OF PLANTS}

Thus it is evident that plants are not helpless victims of circumstance, depending on the charities and wishes of every other creature, but are of themselves thoroughly awake to their importance in the world. Each plant is quite prepared to hold its own against its enemies, to procure the means of its livelihood, to recognise its friends, distrust its foes, to grow, develop, multiply, build up families and enjoy its living, to seize its opportunities, and to create new ones-truly in all ways to progress as man has done.

With humans the art of self-defence has been developed to a science. For every danger and hardship an adequate means of contention has been devised. Such also is the case with plants. Sometimes, like soldiers, banding together for purposes of concerted resistance, sometimes fighting alone, they wield against each enemy the weapon which is most effective; for the plants' weapons are quite as numerous as their enemies. Thorns, prickles, poisons, sticky excretions, odours, stinging hairs, and many others are the defensive weapons used.

Perhaps the common hawthorn is one of the best examples of the self-reliance and independence of plants. Through ages of experience this plant has learned to resist the attacks of all destructive 


\section{PLANTS DEFEND THEMSELVES 37}

forces. Horses, cattle, and sheep fear and avoid it; small animals dodge around it; even man refrains from too much intimacy. It has developed an extremely sharp thorn at the end of each branch; at the base of the branch is a bunch of spine-like needles or thorns; and, in addition, each branch forms in itself a row of dagger-like points; the whole presenting a formidable resistance to the onslaughts of destroying animals. And yet, even as with the strongest of humans, the hawthorn has its annoying, small enemies-numbers of themsuch as caterpillars and fungi, which it cannot fight, but must tolerate. The hawthorn is, however, one of the most independent of plants; and being, like man, of sociable nature, as soon as its success in any locality is assured it begins to gather around it many agreeable neighbours.

There are three types of dangers against which all plant life is forced to defend itself: insect pests; voracious animal and plant life; and destructive natural forces.

For the land plants, the wingless insects, such as ants, are the chief enemies in the pest class. In plant life there is a rule that all insects which do not give value received must be repelled. The flying insect, in acting as a carrier of pollen from plant to plant, earns the right to sip honey from 


\section{THE HUMAN SIDE OF PLANTS}

the heart of the flowers. But against the crawling insect, which comes to take without giving, all plant forces are arrayed; for any pollen which the wingless insect may carry from the plant is lost in descending the stem, or is shaken off in the grass, and therefore wasted.

It is not uncommon to find the nectar or honey stored deep in a long, trumpet-shaped tube-as in the honeysuckle, for instance; in the nasturtium, or the columbine-so that only the welcome guests may partake of the feast by means of a long proboscis, or sucking organ, which has been especially developed for that purpose. At times, however, even this device is insufficient. Prowling bees and insects, unable to gain admission at the proper entrance, will bore through the wall of the flower and steal the honey within. But in this case the plant answers the attack by developing poisonous or ill-tasting juices in the fibres of the flower-wall, thus keeping the insect away. For every enemy there is a remedy: the plant is supplied according to its needs.

Very many plants shape their flowers so as to protect the honey against the ravages of useless insects, saving it to tempt the pollen-bearers. In the common toad-flax, or "butter-and-eggs," the petals form closed doors to a small insect; but a 


\section{PLANTS DEFEND THEMSELVES 39}

bee, on a honey-gathering trip, attracted by the brilliant touch of colour at the tip of the blossom, alights on the end of the lower petal, his weight bears it down, opening the door, and he walks in and has his feast, incidentally brushing the pollen as he passes.

This means of protection-the shape of the flower-is only one of many means followed by various plants. Every observant person has noticed the glossy, varnish-like stems which some plants have. This varnish-covering is another means of defence utilised by the ingenious plants. That surface with its glossy sheen presents a footing far too slippery for any of the nimble-footed ants and their kin to ascend; and so against such incursions the honey-well is secured. The catkins of the willow show this condition admirably: over their surfaces is temptingly displayed a nectar, so sweet and seductive that winged pollen-bearers are attracted from all directions to the enjoyment of the repast, but this same exudation renders the stem so slippery and impassable that the grasping wingless insect cannot ascend.

Another very common defence against the crawling pest is a sticky glue, which, instead of allowing the marauding intruder to slip back, holds him fast, a prisoner dying in sight of the joys that have 


\section{THE HUMAN SIDE OF PLAN'TS}

lured him to destruction. It is reasonable to suppose that in the distant future some of these plants which win their prey by means of viscid hairs or surfaces will develop into insect-eating plants, as the sundew, Venus's fly-catcher, the pitcher-plants, $\rightarrow$ : and one of the bladderworts have done. Darwin believed that many plants, such as the saxifrages, not classed with insect-eaters, actually get some food from the trapped insects.

But the mere fact that a plant catches insects is no proof of its carnivorous nature. Numerous plants have their leaves and stems covered with sticky hairs, which continually catch insects; and yet, they show not the slightest tendency to absorb or digest the food thus captured. The stems and leaves of the rhododendron, some species of solanum, and the stinking groundsel, all use this method of trapping unwelcome visitors.

An interesting evidence of the discretionary powers of these plants is the fact that when cold weather drives away or kills the crawling insect life, this stickiness ceases. The need no longer exists, and the supply dries up. In the same way, the gummy fluid on the scales which enfold the leaf-buds of the horse-chestnut and the balsam poplar, in the springtime, disappears when no longer needed. 


\section{PLANTS DEFEND THEMSELVES 41}

There are some plants which show their reasoning in a different method of defence against their insect enemies. Knowing that at night they are safe from the wingless pest, while the night moths and their allied pollen-distributors will still be at work, these plants open only during a few hours of the night, and send forth into the darkness sweet odours to call the flying messengers. These plants usually develop no means of protection other than the habit of night blooming: this provision is adequate. An exception, however, is the Jimson-weed (Datura Stramonium), which not only emits a rank odour to ward off unwelcome insects, but goes to the further pains of covering its large fruit pods with stout prickles. One of the most beautiful of the night plants is the night-blooming cereus, which has a perfume so strong and so sweet that it drowns all other odours near it.

A means of defence similar to that adopted by the night-bloomers is shown by those plants which bloom only in the early morning, when, because of the dew-sprinkled ground, they know no insects will be stirring. The rising sun warns them that it is time to close, and, obedient to his warning, they draw the shutters against the approach of the gluttonous, crawling pests.

The plants which avoid their insect enemies by 
coming out only when they know the pests will not be around are in somewhat the same class as the morally weak plants which buy off or pay "blackmail" to their enemies. The bird-cherry is one of this type; many of the vetches also bribe their crawling ravagers by feeding them from a special supply of nectar that is stored in epidermic cells on the under side of the leaves. Insects, mounting the stems in quest of alluring sweets, make the most of the first supply that comes to hand, revelling on this until their desire is satisfied, and then dropping off in a state of drunken satiation, entirely fooled by the ingenious plant and thwarted in their quest for the rarest wines which have lain just beyond. It is the oldest of human tricks!

Weapons are the most evident means of defence. man has; and to plants, thorns, spears, and daggers form a very useful and common protection. But the thorns and daggers on plant stems have not, as many people think, like Topsy, "jes' growed." Those plants which have adopted external weapons as a means of self-defence have done so with thought and consistency. One who notes the position and arrangement of thorn armour will see that all spikes and daggers point down to meet the scaling forces. The guerilla worm or insect 


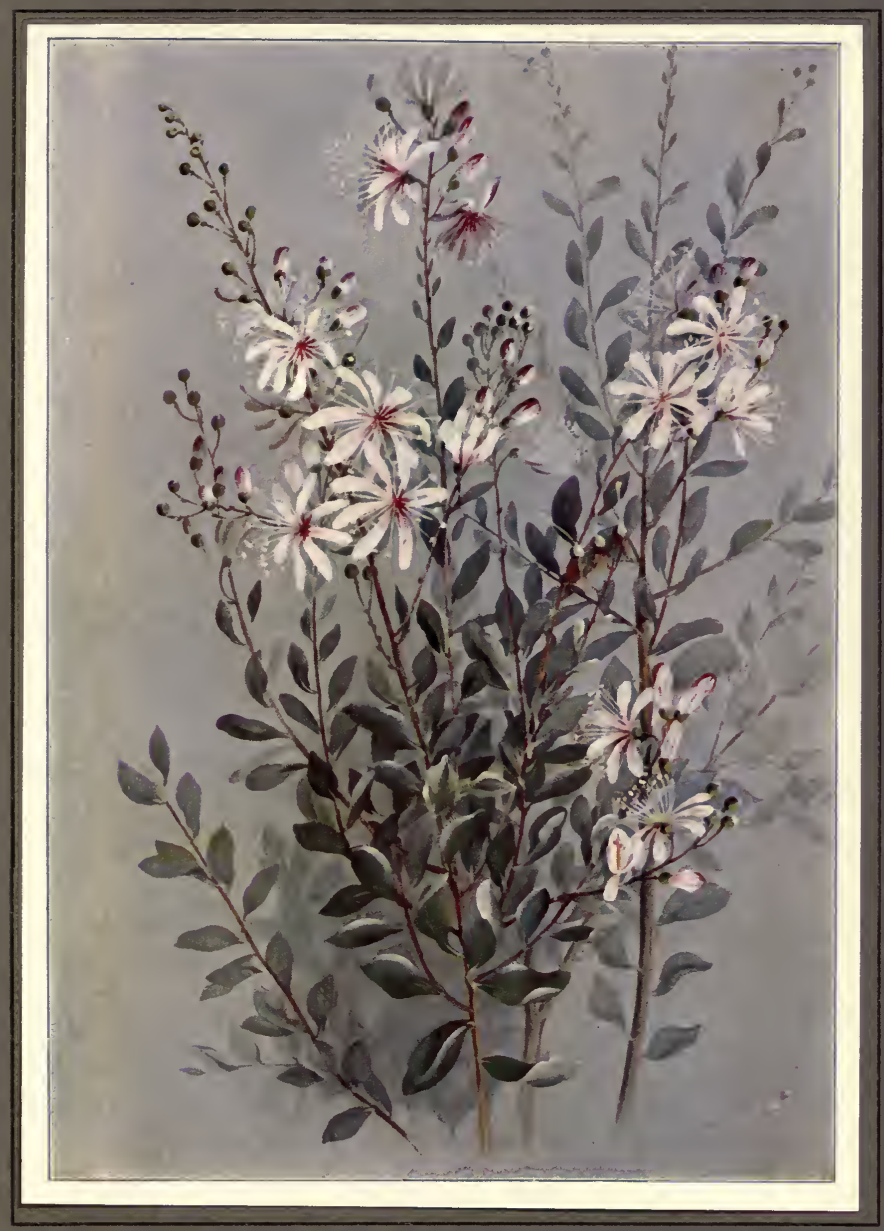

TAR-FLOWER Bejaria racemora.

To protect its honey-laden flowers from crawling insects, the plant covers its stalks with bristly hairs. 

that attempts to take any thorned plant's treasure by storm will find the first steps easy, but as he progresses nearer and nearer to the goal, the opposing points become more numerous, until the way at last becomes impassable. No matter how the worm turns, a hard point of needle sharpness waits to impale him. The familiar thistle is such an armed force, a thing dreaded of robber insects and voracious animals alike, for its cruel, dagger points; yet the pollen-bearing honey-bee rests in a soft bed of purple down and drinks his fill unheeding and untroubled by the bristling, impregnable armament which makes his source of supply inaccessible to the marauders below.

The tar-flower (Bejaria racemosa), growing as it does in the pine barrens of the Southern States, without its armour of prickly hairs would stand little chance of survival. Its blossoms are a dainty white with a delicate pinkish tinge, and its leaves are a glossy olive-green. Grazing animals have learned to give it a wide berth on account of its prickles, and thus it is allowed to flourish unmolested.

Aquatic plants meet with a different type of insect foes, but their means of defence is largely similar to that of land plants. Against larvæ and other small aquatic life, they have developed sting- 


\section{THE HUMAN SIDE OF PLANTS}

ing hairs, poison darts, and various other weapons of defence; while acrid juices, poisons, and tough, fibrous growths assure safety from both insect and larger animal life. Some plants shoot their heads above the surface of the water, to avoid the attack of water insects; and then, in order to prevent their enemies from climbing up the stems to the heads, they exude a thick, viscid varnish, which both opposes the passage of insects and protects the plant against inclement weather conditions.

Against the second general danger to plant life -voracious animals and voracious or hostile plants - there are four common means of defence: thorny or dagger-like weapons; acrid or poisonous qualities; off ensive odours; and simulation and flight.

The first defence is very common. Cattle have learned in the past to avoid spinous or prickly plants, the knowledge of the danger of interference with such plants, which ancestor cattle have learned by painful experience, having become an inherited antipathy in their descendants.

Against plants and grasses which secrete silica this antipathy is apparent also; and with good reason. All animals intuitively have learned to avoid the rough, "cutting" grasses and the bristly plants. As the humans in ages past mixed iron with their copper to make the weapons more durable, so have 


\section{PLANTS DEFEND THEMSELVES 45}

the plants hardened their blades with silica. The common horsetail, a plant of this species, makes deadly sick those unwise cattle and sheep which attempt to eat it.

There are many juices and poisonous secretions used by plants in defending themselves against animal life. One of the most common of these is tannin. It is found in the bark of many trees: in the beech, the walnut, the pecan, and the hickory, in the tropical acacia, in several of the oaks, beneath the shells of nuts, and encasing the reproductive germ in most fruits.

Here once more is evidence of the reasoning power of plants. Their one great aim is reproduction - the perpetuation of their kind. To this end all thought and action in plant life is directed. It is for this reason that the winged insect, a pollencarrier, is given entrée to the soul of the plant, while the crawler, not a pollen-bearer, is resisted with every power. To the plant mind or instinct, the preservation of the fruit is nothing-it is merely a soft covering for the germ inside; but the preservation of the germ, the reproductive possibility, is everything. Hence the fruit is an edible, inviting thing; but the "stone" or "pit" is a hard, indigestible piece of "waste," which is thrown aside. Thus it is provided an opportunity to germinate in new 


\section{THE HUMAN SIDE OF PLAN'TS}

fields, and so the original purpose of the parent plant is accomplished.

The sourness and bitterness of unripe fruits are due to the temporary secretion of acids in order to keep off attacking animals and birds until the seeds are ripe and ready for distribution. This sourness is merely a defensive move; once the seeds are ready, the plant softens and sweetens its fruits in order to attract to itself with its sweetness the unintentional seed-carrier.

Odours form a strong protective force in use by many kinds of plants. These by their off ensiveness ward off the attacks of depredatious animals and insects which otherwise would destroy them. There are many familiar examples of this means of defence: the skunk-cabbage, the Datura, snakeroot) tobacco, and many other plants employ it; one of the St. John's-worts has an odour like that of a goat.

In the world of humans there are always a number who "fight with their heels," who run from danger to the shelter and protection of some stronger person or force. The plants which seek safety in flight are not so numerous as are the humans, but there are several types of grasses and plants which do so. In southern Texas and northern Mexico there is a well-known grass, much 
sought after by grazing cattle and sheep, called the Muhlenbergia Texana. This grass probably would have become extinct long ago, growing as it does in almost desert soil where pasturage is so much in demand, had it not sought refuge beneath the thorny branches of cacti and mesquite bushes. The cattle fear too familiar proximity to the thousand-pointed cactus, and so, in spite of the seductive freshness of the Muhlenbergia, they leave it to flourish in peace under the protection of its spiny and dagger-armed guardian. Even young sheep have learned not to try to reach it, lest they become hopelessly grasped by the prickly cactus, whose sheltering arms defend not only the grass but ofttimes a happy family consisting of rattlesnakes, prairie dogs, and the prairie owl.

With plants that run away to the protection of stronger plants should be grouped those which hide from their depredators. There are many of these, some of which are very cunning in their methods of escaping detection. Weeds frequently hide in among plants which are very similar to themselves: wild seedling lilies are often found among Solomon's-seal; June grass flourishes undisturbed among beds of phlox; nightshade grows among tomato plants; wild onions slip in among their cultivated cousins; daisies love the com- 


\section{THE HUMAN SIDE OF PLANTS}

pany of bachelor's-buttons; and dandelions frequently grow among turnips and radishes. These clever habits allow many a plant that otherwise would be destroyed as a useless weed to have a permanent home and to bear fruit.

Another example of the cleverness of plants in protecting themselves is the growth of all kinds of nuts on the trees. During the time of development they are green, the colour of the foliage, and therefore hardly discernible; when, however, they are ready to fall to the earth in order to start new trees, they change to dark brown, the colour of the ground on which they are soon to rest. The hazelnut is especially clever in its disguise, the nut being enclosed in a leaf-like green bract, which by its resemblance to the other leaves very effectually hides the nut from view. The walnut has a hard spongy covering filled with an acrid juice which is exceedingly distasteful even after the fruit has dropped to the ground.

In waging war among themselves not always the stronger plant is victorious; ofttimes, apparently, the weaker uses ingenious methods and wins in the struggle for existence. Especially is this true of weak vines with delicate stems; the common morning-glory, for example, climbs right over its more gifted neighbours, reaching its ambitious flowers 
and leaves up into the sunlight, and practically enslaving all its neighbours by using them as props for its own progressive self. Like its cousin, the parasitic dodder, it not only uses but often kills other plants that come in its way. However, plant victories, like human victories, are frequently only temporary: in time the conquered species gradually regain their former positions and become the conquerors.

The changing of a river bed, continuous droughts, even a severe storm that brings seed from other places, is all that is necessary to change entirely the flora of a small region. If one plant cannot successfully grow in a region, another kind soon drives it out and takes possession.

Climatic conditions are not the least of the great forces against which plants must defend themselves. These conditions are rain, cold, heat, wind, and lack of water. The instinct of self-preservation is yery clearly shown here. An evidence of the voluntary protective action of the plant against climatic conditions is that of the cacti of the desert. In an environment where the water supply is very scarce they have learned that, when a shower does come, special provision must be made for storing away, against the long months of drought that must follow, as much water as they are capable of 


\section{THE HUMAN SIDE OF PLANTS}

holding. To this end the inner walls of the cacti are filled with sponges which can absorb immense quantities of water. The roots travel great distances into the earth to take up the moisture. This is one of the reasons for the coating of daggers and hooks which cover every part of the cacti. Without these weapons they would be destroyed by the hungry and thirsty animal life of the desert.

The cocoanut has been forced by many hard knocks to learn to defend itself not only against inclement weather but also against salt water. The cocoanut grows in the tropics and usually near the shores, where it has been planted by the tides. Here new plants spring up; and because they grow beside the sea and the probability is that the fruit will fall into the water, the plant has provided for this emergency. In the first place there is the long, fibrous covering of the nut, which prevents the salt water from entering and spoiling the fruit; then there is the impenetrable shell, a strong protection against most forms of animal life. Also, the nut is of such shape that it floats very readily, and it is not unusual to see two or three cocoanuts drifting to a distant island or shore, as children run to new playgrounds.

There are some plants which seek protection from adverse weather in sheltered spots. Such are 


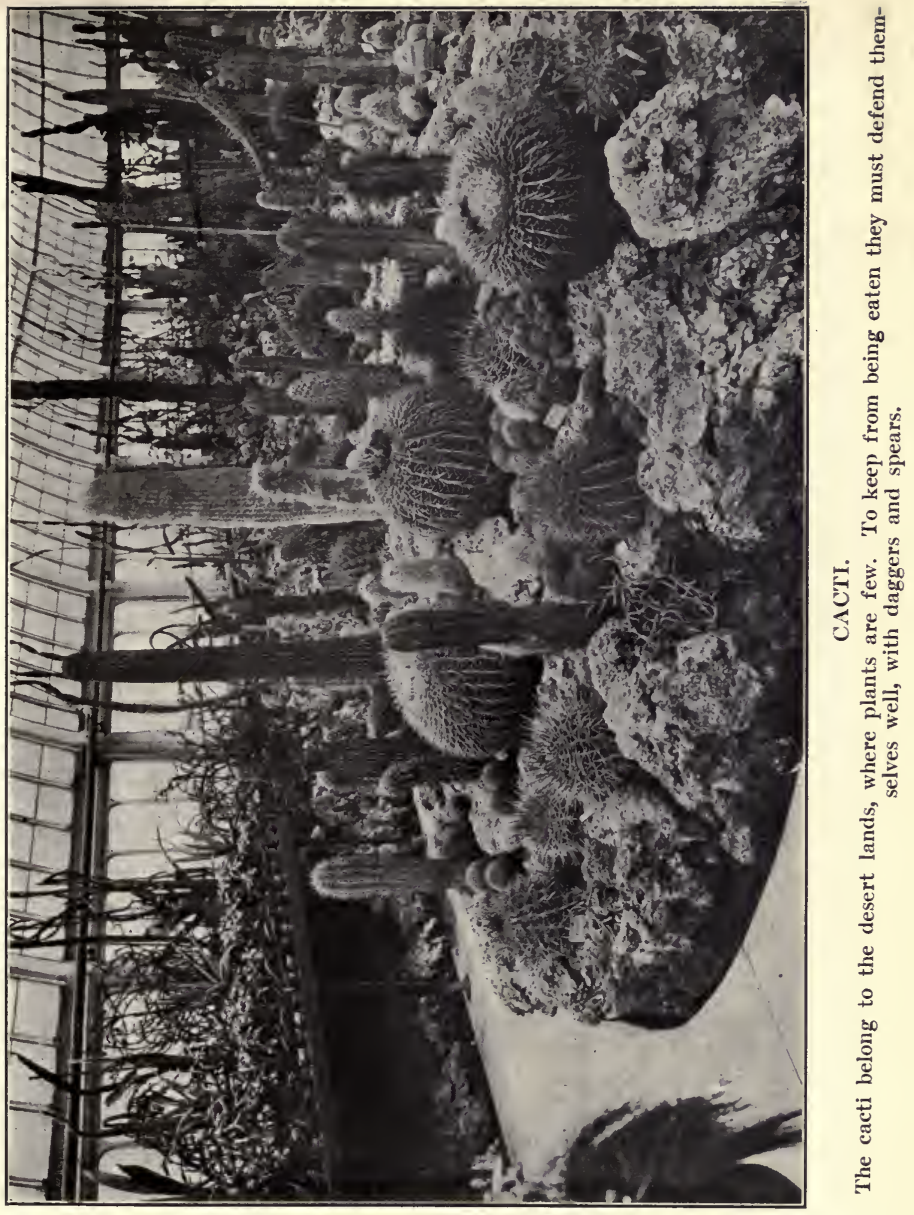




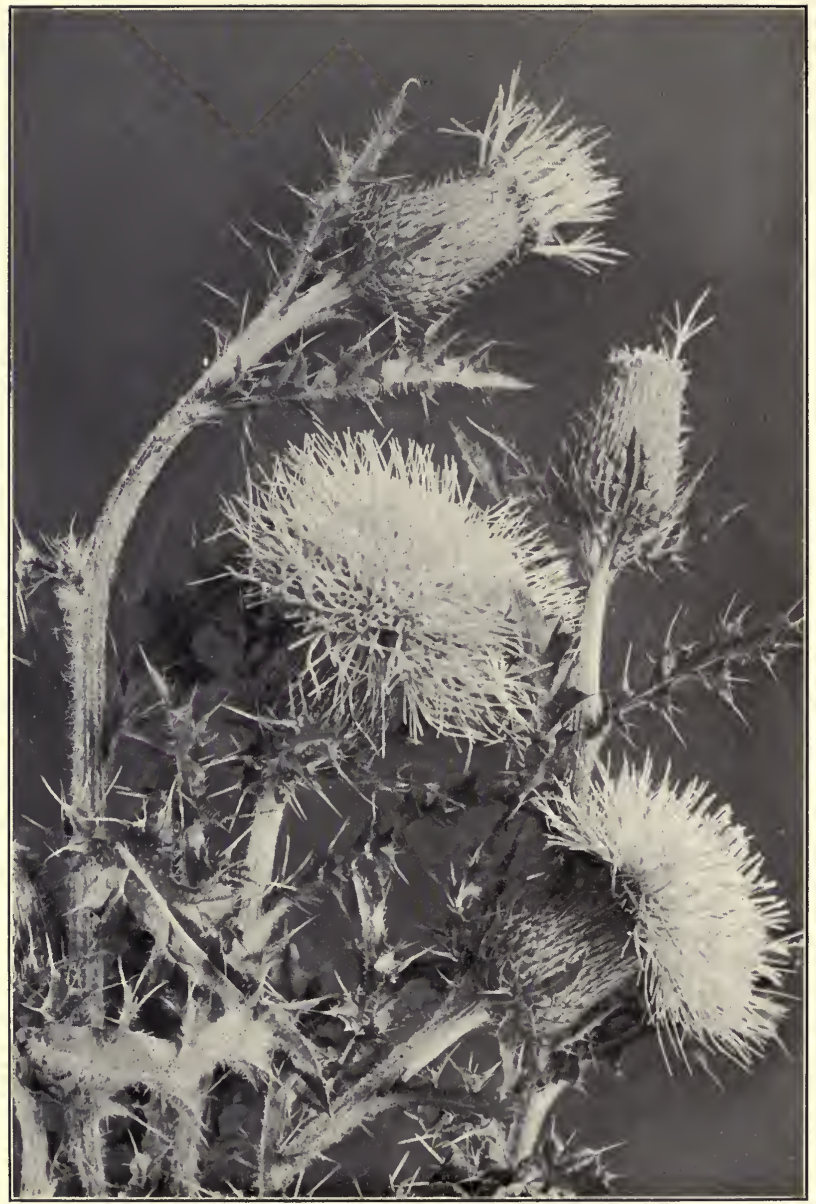

GLOBE THISTLE. Echinops.

Its many spears are always ready for defence. 


\section{PLANTS DEFEND THEMSELVES 51}

the little plants, like mosses and bluets, which grow behind rocks and in deep glens, where they are protected from wind and too much sun.

There are other plants which close their blossoms at the least sign of rain, opening them again in sunshine. The pimpernel does this with such consistency that it is called the poor-man's weathe glass.

Cold weather is believed by many people to kill practically all the plants. 'This, of course, is as untrue as it would be to say that the bear, hibernating in his den until the warm spring sun shall call him forth, has been killed by the cold weather. There are many aquatic plants which, flourishing beautifully during the warm months, as autumn approaches gradually dry up and drop to the bottom of the water until the winter is over. Then they send forth tender young shoots and begin a new year of life. Their so-called "death" has been merely hibernation, a prudent attention to the intuitive warning which has come to them to guard themselves against the cold. It is but a strong evidence of the active and dominant instinct of selfdefence in plant life. 


\section{VI}

PLANTS THAT KEEP A STANDING ARMY AND NAVY; PLANTS THAT EMPLOY AN AERIAL SQUADRON;

PLANTS THAT KEEP SERVANTS AND

LIVE STOCK

HERY great power or nation has found it
necessary to keep a standing army; and, usually, the greater the nation, the larger the army. It has been learned that the armed-nation system is an incentive to peace; while war means waste and general disaster. Hence the value of the standing army.

This moral effect of keeping a standing army is as apparent to plants as to men. There are some plants which wage warfare; others, being rich, pay "blackmail" to their enemies, rather than fight against them; some actually hire soldiers and maintain an armed protective system. This is especially true of certain plants growing in the tropics, which are besieged by so many kinds of enemies, of both the flying and the crawling type, that without their armies they would be totally destroyed. 


\section{PLANTS THAT KEEP AN ARMY}

The vetches are of the class of plants which make a practice of bribing creeping and crawling insects to leave their honey untouched because they know that they must be fertilised by flying insects. In addition to the sweets stored in their blossoms, the plants have tiny glands, filled with sugar, located below the flower; and this is offered as a bribe to the unwelcome, crawling guest. But this is not all the protection the plant has: there are numerous sharp-pointed hairs protecting the passage-way to the flowers. As a result of these precautions, the ant usually eats the proffered sweets and leaves the nectar in the blossoms for more favoured winged insects, who pay for their honey by distributing the pollen of the plant.

Many plants make servants, or allies, of the ants; and others keep such a vast number of protectors that they may be termed their "standing armies."

A good example of plants that keep servants and live stock is one of the ferns, Polypodium nectariferum. This fern receives ants as most welcome guests and allies; it furnishes them with a good home and food in the form of honey; in return they protect the fern from various forms of insects and leaf-cutting ants, thus maintaining mutually satisfactory arrangements.

Not the least singular instance of intelligence dis- 


\section{THE HUMAN SIDE OF PLANTS}

played by plants in protecting themselves against their enemies is that of an acacia of South America. This tree, sometimes known as "Bull's-horn thorn," is surrounded by such vast hordes of enemies that it is necessary for it to keep a standing army to guard against the depredations of its foes. To this end it has developed a most ingenious plan. Its branches are covered with curious hollow thorns, and at the base of each leaflet is a small gland which secretes honey. Colonies of ants occupy the cavities in the thorns, and feed from the honey. The ants are naturally interested in their home, and, when it is attacked by enemies - such as moths, or leaf-cutting ants-the occupants of the tree pour down upon them like an army of warriors. As a result, the wise acacia is well protected in return for the board and lodging supplied to its standing army.

But plants which keep a standing army must tolerate the servants, guests, farmers, nurses, dogs, milk cows, horses, pets, scavengers and parasitesin fact, the whole retinue of camp-followers which is incident to every armed force. Possibly the most human traits among the habits of these intelligent ants are their well-known farming, animal-raising, and slave-holding habits. The very fact that ants, keep these hundreds of servants and allies assures 


\section{PLANTS THAT KEEP AN ARMY 55}

extra protection to the acacia. Of course, their milk cows, which are species of beetles, also a kind of caterpillar, and cochineal, must be stationed out in herds on various parts of the tree; and each herd is separated and carefully guarded by a herdsman; and he, in turn, is accompanied by several small animals, obviously as watch-dogs. As a colony of ants and their helpers are capable of destroying hundreds of caterpillars and grasshoppers a day, and as they work day and night, the tree is well protected.

In still another way do the servants of the plant prove a benefit to it: in addition to destroying or driving away the larger marauders they eat the minute parasites.

There are plants which do not produce honey with which to pay their armies; in such a case it is usually found that the plant is already inhabited by a number of insects, which can supply milk and meat to the warrior inhabitants; and so slave-holding ants take possession of the tree as a desirable dwelling-place on which to raise their army of allies. One form of beetle, raised in the underground nests of these ants, secretes and produces a sweet fluid, that might be an intoxicant.

Another plant of the tropical regions which keeps not only its own standing army, but also its 


\section{THE HUMAN SIDE OF PLANTS}

defensive navy, is the now famous gigantic waterlily, Victoria Regia.

Few there are who have not heard or read glowing accounts of its colossal size and its wondrous beauty; fewer there are who, having once seen it reposing on the surface of the water in its majestic richness of colours and almost titanic proportions among the plant species, can ever forget the wondering admiration they felt on first viewing it!

The gigantic leaves of the Regia grow to proportions of five or six feet in diameter, and lie on the water like great circular rafts, with turned-up edges. These leaves themselves are of such choice colouring as to deserve the appellation of flowers. They are of soft shades of light green above-and seem like pools of clear green water in the midst of the browner surrounding waters. Underneath they are in varying rich tints of red, a red that contrasts beautifully with the light green upper surface, and which forms a marked outer-wall for the rim.

But the beauty of the broad leaves seems but to lead up to the delicate, radiant glory of the great pink and white blossoms. Pink and white is the impression one gets of them, but on closer observation they are seen to vary from a deep rose red in the fragrant centre, through gradual reds and 


\section{PLANTS THAT KEEP AN ARMY 57}

pinks, to the snowy whiteness of the outside. These blossoms, many of them a foot or more in diameter, raise their graceful heads above the waters with truly regal majesty, verily queens of the sea.

Assuredly the Regia is well named for the great ruler of that nation which has been called the "Queen of the Seas," for, with its gigantic leaves and its gorgeously blazing blossoms, what can it be said to resemble more than a great floating navy? And truly the Regia is a navy, for each of its ponderous broad leaves forms a great "dreadnaught," manned with an active fighting crew, in the shape of the numerous water-birds, which find in the wide deep-rimmed pads of the lily a safe and dry footing.

It is these birds which form the standing army of the queen lily; better, perhaps, call them the aerial, standing, and swimming armies, for among their numbers are birds of all three kinds. It has been said that no less than a dozen tropical birds are accustomed to make use of the lily pads as their boats.

The birds catch fish from their vantage-point on the leaves; and they feed on the hundreds of aquatic insects and snails which swarm about the under surface of the pads. As many of these insects would be harmful to the plant, were they allowed free 


\section{THE HUMAN SIDE OF PLANTS}

rein, the Regia is more than repaid for the support she gives to her standing army.

One of the most interesting features of pond life are smaller water-lilies. Their broad leaves are the floating homes of myriads of tiny animal life of both the water and the air. Young frogs hold concerts on them; and tiny fishes seek shelter in their shadows.

Of course, the fact that plants maintain for their support or protection other forms of life than their own is shown in every form of plant life that exists.

The bees which carry pollen may be called the servants of the flowers; the birds which swing among the branches of the fruit-trees are constantly fighting in behalf of the tree, thus protecting its young and undeveloped seeds from ravaging insects; the very snakes and toads, hiding among the grasses, protect those grasses from harmful grubs; and in each instance the insect or animal is serving or protecting the plant, is filling the position of servant or soldier to that plant.

However, no service in plant life, as in the world of human beings, is without its remuneration. The animal gives to the plant, but the plant also gives to the animal. If the bee carries pollen for the flower, the blossom yields of its sweet honey to his 


\section{PLANTS THAT KEEP AN ARMY 59}

need. If the bird drives off the ravaging insect, he later enjoys the luscious fruit and finds a foundation for his nest on the branches of the tree; if he protects the young, unripe seeds of the tree, it in turn shelters his young from harm with its grateful leaves. If the snake drives off the grub from the grasses, he finds seclusion among the roots-and how frequently has the club or stone of his pursuer been turned aside or caught in the tangled grasses sufficiently to give him his chance to escape!

Truly there is a camaraderie, a spirit of give and take, in this condition of apparent servitude of one creature or plant to another, which preaches its own deep lesson. It has debarred the "labour problem" from the realms of Plantdom and Creaturedom. It is a moral concession to the Law of Compensation; that is the secret of the plant's standing army! 


\section{VII}

PLANTS THAT ROB, PLUNDER, AND MURDER

"In the meek garb of modest worth disguised, The eye averted and the smile chastised, With sly approach they spread their dangerous charms, And round their victims wind their wiry arms."

AONG the interesting things in nature, per-> - haps none are more striking than the many plants which, like human beings and animals, rob, plunder, and murder. These things they do for many causes, but their main object is personal gain: they either do not wish to work, or they have become so degradingly poor that they have been forced to become robbers and so live by the effort of some honest, working plant. These paupers must have food and nourishment, and they secure it by robbery. Some actually commit murder, sucking the last drop of vitality out of the host plant; others are only petty thieves, and do not actually kill their host, but seem merely to seek sufficient food to keep themselves alive and healthy; still others appear 


\section{PLANTS THAT ROB AND MURDER 61}

to form a kind of partnership with the host, whereby each is equally benefited. All such plants are degenerates and may justly be termed vampires.

Robber plants have two ways of living: one kind, such as the dodder, thrives upon living plants; the other, such as puff-balls, mushrooms, and toadstools, feeds upon a food material already prepared by other plants or by animals. The other form of parasite, like the mistletoe, which is partially honest, pays for some of its food; it may therefore be politely classed as the "borrowing friend" rather than the "highway robber."

A striking example of a murderous parasite, or robber plant, is the dodder-or Devil's-thread, as it is termed in many parts of Europe. Botanists refer to it as the Cuscuta. It has many relatives, among which even the respectable and honest-working cypress and morning-glory vines are numbered. Such a plant as the dodder has no green colouring-matter, chlorophyll, in its body, and it is therefore unable to secure food for itself, because it is by means of chlorophyll that plants are enabled to make food from the inorganic compounds furnished to them by nature.

The dodder has no leaves, nor does it need any, as it gets all its food from the plant on which it grows; it has a few small scales that are possibly 


\section{THE HUMAN SIDE OF PLAN'TS}

the last remnants of lost leaves. At the beginning of this interesting plant's life, the seed germinates in the earth, as if it intended to grow and work as other plants do; soon, however, the delicate little vine begins reaching up for aid, until it has grown tall enough to reach a clover, or a flax plant, to which it immediately attaches itself by means of little filaments or suckers. As soon as it has a firm grasp on some healthy plant, it begins to wither near the ground, and soon all connection with the earth is broken. Thus the dodder crawls and twists itself over the heads of numerous plants like a writhing snake, binding them fast with its vampire suckers and taking its food directly from them-flourishing at their expense, a thief and a robber indeed!

The other habits of this strange robber are strikingly like those of its honest cousins, the cypress vine and the morning-glory. It often grows many feet in length, twining itself about the tops and leaves of plants, and sewing them together like bunches of cord-bound stems. Its flowers are of a pale, whitish hue, and are almost bell-shaped, growing in small, ivory-like clusters. In the South it is not uncommon to see large fields of weeds literally yellow with the death-twining cords of the dodder; each closely sewed to its neighbour by this 
Devil's-thread, whose luxurious and prolific life is practically unmolested, when once it gets a start.

In great tropical forests there is a spirit of terrible selfishness and combat. Every individual tree and plant seems to be struggling to surpass those about it, heeding no law of social responsibility, but twining itself about the nearest supporting neighbour, reaching, stretching, clawing, caring not what destruction it causes, aiming always upward to the light and air above. The parasites cling everywhere to others, which cannot throw them off. Clearly here in the wilds, as in tribes of uncivilised humans, there is but one law of life, that of the survival of the fittest!

The Murderer Liana is a parasite of the most unscrupulous kind, whose weak stem is unable to support its avaricious and ponderous head, and who therefore clings to its upright neighbours for support. It springs up beside a stalwart tree, and as its stem grows, it spreads out like a soft poultice upon the trunk of the tree. Then it climbs by sending out clinging arms, wrapping them around the body of its victim, and joining them on the other side. Up and up climbs the strangler, always sending out new arms around the stricken tree, and the arms always growing thicker and heavier to support the increasing weight; until at 


\section{THE HUMAN SIDE OF PLAN'TS}

last the Murderer Liana reaches the sunlight above, its leaves flapping insolently into the face of the tree which has helped it to ascend, and which is slowly dying in the choking embrace of the many tightening vampire arms. Eventually the sap of the upright tree is stopped from flowing, and it dies, its dead leaves falling withered to the ground, while the unscrupulous Murderer Liana waves its leaves in the breeze as if exulting over the dead and decaying corpse which it still holds in its grasp.

One of the best-known parasites, or, one might say, petty thieves, as it actually does give something in return for the abundance it receives, is the common mistletoe. It is an evergreen plant with lemon-greenish leaves, which, unlike those of many parasitic plants, do perform the function of leaves; and it is commonly found on oak, poplar, elm, apple, pecan, and many other trees. It germinates from tiny seeds, which are covered with a sticky fluid, and which have been carried by birds and planted on the host-tree.

Perhaps no other form of plant life is so dependent on the birds as mistletoe.

When the seeds, left by the bird planter, have germinated they begin to send down a tiny rootlet into the bark of the tree. As the branch of the tree-host continues to grow, the mistletoe 


\section{PLANTS THAT ROB AND MURDER 65}

rootlet gradually establishes a union so close between the host and the guest that the food of the host is easily stolen by the robber. Yet, the mistletoe is not a real robber; for, while it absorbs the food of the host-tree during a large part of the year, during the winter months, when the tree has shed its leaves and is therefore unable to feed itself, the grateful guest actually contributes to the host food it has produced from the air and sunshine, and in this way partially repays it for past favours.

Mistletoe has been a favourite for decoration since the earliest times. Many strange superstitions have been connected with it, and especially with its healing powers. Its nature is now so thoroughly understood that it may be cultivated easily by planting the sticky seeds on the branches of a tree. Not only is it attractive for decorations indoors, but it is highly pleasing when seen among the branches of barren trees in winter. And in addition to its attractive appearance, it supplies food, by means of its small berries, for many kinds of song birds in the winter. Coming at a time when most fruits and berries are gone, it is doubly welcome.

There are certain species of mistletoe which are wholly parasitic. There is a leafless mistletoe which is found on a leafless cactus. It grows 


\section{THE HUMAN SIDE OF PLANTS}

abundantly; and a striking thing in its appearance is the reddish-pink colour of its stems.

Other "petty thieves" are the Castilleja, or painted-cup, Gerardias, and numerous other small plants.

It is generally known that plants which are wholly parasitic in habit have, with a few exceptions, lost their green colouring-matter; and many have lost their leaves. On the other hand, those which are only half parasitic in habit still have the colouring-matter in their leaves, but, like the mistletoe, the leaves have a pale greenish tinge, suggestive of degeneration into yellow.

Plants are likely to become robbers and murderers only when driven to it by unavoidable conditions, such as are found in the great forests and in the tropical jungles, where the trees and plants are so closely tangled that their heads intermingle, forming an almost impenetrable canopy above and refusing sunlight to the ground plants and less altitudinous trees. These minor plants are forced, in order to live, to fight their way, by fair means or foul, up to the sunlight: unless they do so, they must weaken and die in the gloomy undergrowth below. It is the eternal struggle, the fight to exist, with the lower plants either dying out or degenerating under the oppression of the higher 


\section{PLANTS THAT ROB AND MURDER 67}

plants, unless they resort to violence and unscrupulous force to gain their means of living.

The common vine-bamboo is a parasitic tropical plant; but it is not so bloodily inclined as are many of its fellows. It seems content to sprawl about on whatever tree or branch its trailers happen to meet, thankfully accepting this bit of support, as the begging human vagrant accepts the bit of bread or money which some generous fellowman has tossed him.

This is one of the kindlier, more harmless parasites, which has not the inclination or the energy deliberately to injure a friendly neighbour; but there are many, many plants in the tropics which hesitate at no bounds in their selfish avarice. They writhe and cling about their victims, climbing over them, bearing them down, choking them, frequently crippling or killing them.

Yet, strangely enough, there are few of these more unscrupulous parasites which are unbeautiful to see; most of them are among the most lovely of the plant species. Their flowers, swaying far up among the honest, dull leaves of some righteous, sturdy tree, seem to be luring their less attractive neighbours out of the straight and narrow path of virtuous industry into the blossoming glory of parasitic idleness. With their gracefully twining 


\section{THE HUMAN SIDE OF PLAN'TS}

bodies and their beautiful flowers, they are like human vampires clinging to their victims, gloating over their conquest, and shamelessly flaunting their ill-won charms into the faces of their fellow-plants.

Such a beautiful, shapely thing is the razor-grass. Having climbed a dozen feet or so up the sturdy trunk of an upright tree, it allows its long, curving blades to droop over, hanging there in languorous indolence. Truly it is a beautiful thing in both shape and colour. But let your hand touch the edge of one of its gracefully drooping blades! The sharp, saw teeth with which it is thickly armed will cut deep into your flesh. Clothing, skin, and bone need fear this beautiful, heartless thing of the forest.

One of the most interesting phases of these robber plants is found among certain kinds which take on the thieving habit when they choose to, and drop it at will. The cuckoo-pint, of ten found growing high up on the sides of ditches, has a cousin which thrives in Brazil. It is sometimes seen sitting far up in the air, delicately held like a tremendous spider with long straight legs reaching to the earth. Occasionally it takes root, and feeds itself as other plants do from the soil. Like some people, however, it works only when forced to do so by the lack of food. 


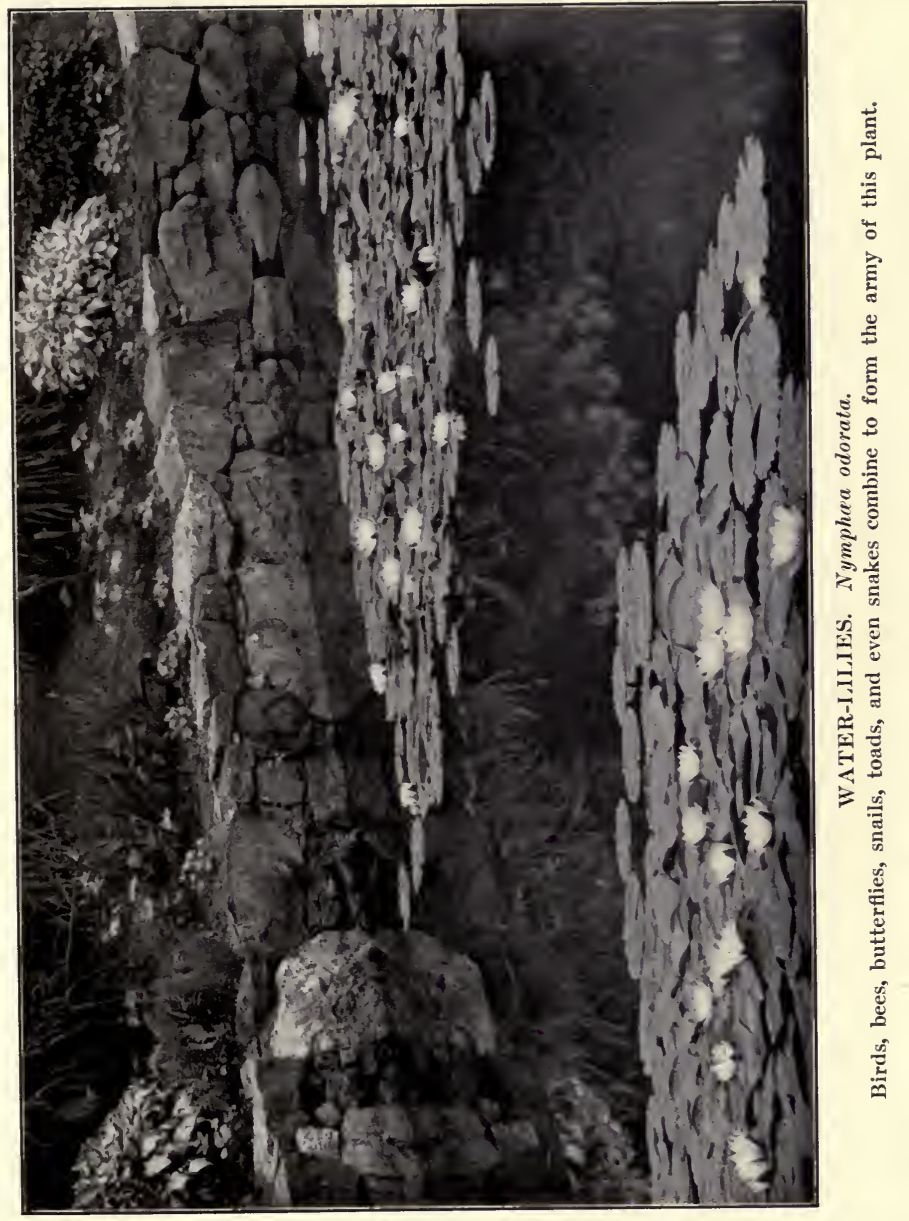




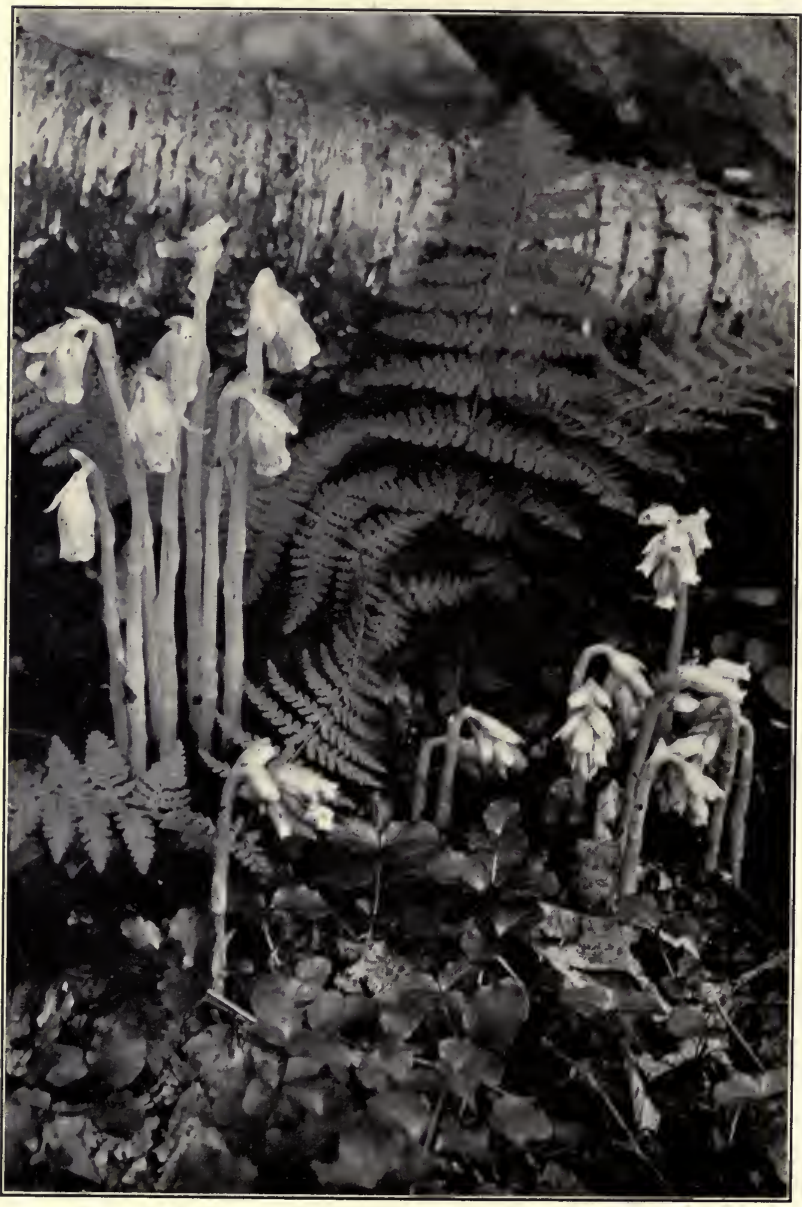

INDIAN PIPE (Monotropa uniflora) and BEECH-DROPS (Monotropa IIypopitys).

These are ghostly looking robber plants which the Indians held in great awe. 


\section{PLANTS THAT ROB AND MURDER 69}

There is a large group of robber plants that belong to the lowly and humble class; they grow on the earth and attach their roots to the roots of other plants, who "can afford to be generous .... and allow a whole world of lesser plants to fatten round their feet." These humble plants have long ago lost all ambition and are satisfied if they can get from their host only enough food on which to live. The broom-rapes exist in this fashion. One species grows freely on tobacco in Kentucky; another type grows on hemp.

Still another interesting robber is the corpse plant, or Indian-pipe. It is a fungus-like plant, with a bunch of fibrous roots growing in decayed vegetable matter or old roots of trees. The bunches of ghostly, white stems have each a large white flower, which turns black immediately upon being plucked. These weird flowers are odourless. They were held in great esteem by the Indians, who regarded each as the symbolic expression of a departed friend.

Then there are the ravaging and ever-increasing parasitical fungi, such as mildews, smuts, rusts, rose-blight, pea-blight, and potato-blight, which thrive largely upon living plants; very rarely, if ever, on the dead. Farmers and florists are ever at war with them; and it is not surprising, for they 


\section{THE HUMAN SIDE OF PLANTS}

attack living plants in multitudinous numbers, like wolves among sheep, or flocks of crows in a cornfield, leaving nothing but death and devastation behind.

Of all the robber plants, perhaps the most interesting, certainly the most beautiful, is the treeloving orchid, which belongs to a big family of plants known as epiphytes. In the truest sense of the word, they are not really robbers, because they seldom obtain their food from the tree on which they are found, but merely a "foothold"; their food comes from the air, through their own leaves. This great family of epiphytes is also represented by mosses and lichens and certain species of ferns; but its most striking member is the much-prized orchid. Of all nature's subjects there is none so gorgeously apparelled.

In the great tropical forests of South America the orchids cling in the tree-tops like small clouds of floating silks that at giddy heights have caught on to limbs of the tall trees. Their shapes and colours are weirdly fantastical: they imitate beetles, butterflies, moths, lizards, toads, scorpions, and sometimes even human faces! In colour nothing could be more extraordinary, nothing more fairylike. Some dress in dark golds and browns; others imitate the spotted reds and blacks of huge poison- 


\section{PLANTS THAT ROB AND MURDER 71}

ous spiders; still others are striped like strange lizards.

From India we get ivory-like species of velvety white and gold; from the American tropics come brilliant specimens whose colours blend so gradually and harmoniously as to form the most charming of floral rainbows. In the Philippine Islands are found eerie moth-orchids, with spikes of flowers which remind one of tinted snow-crystals swinging on a spider's web.

All of these wonderful robber plants seem to have nothing to do but to be beautiful. Lounging in the tree-tops, they laugh in all their glory, bidding mankind to "consider the lilies of the field, how they grow; they toil not, neither do they spin"; and yet these parasitic orchids array themselves so gorgeously as to challenge all imitation! 


\section{VIII}

PLANTS THAT ARE ATHLETES

Plants that roll and tumble; Plants that dress to travel; Plants that hop; Plant high-jumpers; Plants that tie sailor's knots; Plants that shoot; Plant aviators; Plants that canoe; Plants that swim; Plants that dive; Plants that drive hydroplanes; Plants that skate; Plants that travel in ice-boats; Plants that dance; Plants that climb.

PLANTS have as many kinds and forms of
athletics and become quite as skilled in them as do human athletes. They are by no means, freshmen or amateurs trying to "make the team") but they have spent many generations in preparing for the feats which they so skilfully perform in their own peculiar way. Like a sprinter, or a tumbler, a swimmer, diver, dancer, skater, ball-player, or archer-each has to work continually to keep in good condition. Think of a prize-fighter or a wrestler who would not practice! Defeat would surely be his end. And the same is true of plant athletes.

But with the plant, athletics win not popular applause nor money, but life or death. If they lose 


\section{PLANTS THAT ARE ATHLETES 73}

the game, they lose life. And each act of theirs is to benefit not only themselves but also their children. In this they are like human parents, who, in order to benefit their children, frequently make great sacrifices, and often even risk their own lives; in the same way plants take many risks to better the condition of their off spring.

There are a large number of plants which possess the power of spontaneous motion, very similar to that displayed by the lower forms of animals. A striking example of this is found in one of the Algæ, which has an undulating motion precisely like that of certain lower animals. In some forms of fresh-water Algæ, reproduction takes place by the formation of "zoospores" which, though exceedingly small, are covered partly or entirely with tiny cilia or hairs. After these small zoospores free themselves from the parent plant, the cilia begin to move very rapidly. In addition to this vibrating of the cilia, the body of the zoospore itself has a rotating movement on its axis, caused by spontaneous contractions; and as a result of these civilised actions the entire plant passes through the water with a motion very similar to that of a fish swimming. This continues for a period of from one to three hours, as if, in a boy-like water-frolic, the youthful plant were making the most of its 


\section{THE HUMAN SIDE OF PLANTS}

childhood, before settling down to the sterner duties of its adult life. When the plants grow tired of swimming they dive to the bottom to rest on some log or rock, where, if favourable, they attach themselves for life.

Some form of motion is apparent in all kinds of plants, as, for instance, in their growth and creepers; but among the most energetic movements is that displayed by the strange telegraph-plant (Desmodium gyrans) of India. The leaves of this plant are divided into three parts, each of which moves continuously: the two external leaflets, which are small, travelling up and down in distinct jerks; the big leaflet moving only slightly. During the entire life of the plant this motion continues.

A most wonderful example of a plant that rolls and tumbles is the Rose of Jericho. This plant is not really a rose at all, but is one of the Cruciferce; it grows on the dry deserts of Arabia, and near Jerusalem. It is sometimes known as the "Resurrection-plant," and is regarded with much awe and reverence by the natives who sell it to travellers. When all the moisture goes out of the soil, the plant becomes hard and dry, its delicate branches roll up into a ball-shape, its seed-pods tightly close, and it draws up its small roots from the hot sands at the least provocation; then, 


\section{PLANTS THAT ARE ATHLETES 75}

"packed-up" and clad in its brown travelling suit, it is ready to start on a wild, care-free frolic, for all the world like a healthy boy, giving expression to his exuberant spirits. Soon the wind comes, and away the Rose of Jericho rolls and tumbles; here and there it looks for a damp spot on which it may rest and begin life over. At last it finds a pool of water, and here it stops, drinks its fill of water, unfurls its branches, sends down its roots, unpacks and shakes its seeds out on the damp sands, where they may have plenty of water and will be given a fair chance in life. Then the parent plant opens fresh leaves and buds, and, donning a soft suit of tender green in place of its old brown travelling clothes, it settles down, wearied from its long and strenuous exercise, to rest by the lovely, cool water. And unfurling in this refreshing spot, it is transformed from the dry brown ball into a tender green plant. This power of resurrecting itself has given it the appropriate name of Resurrection-plant. It has been mentioned several times in the Bible, and not infrequently in Eastern history.

Another plant which has this habit of rolling is the Selagenella convolvulata. This interesting tumbler grows in South America. When it wishes to travel to a new home, it rolls up in the form of a ball and patiently awaits the first piping wind, to 


\section{THE HUMAN SIDE OF PLANTS}

which it dances and tumbles like a frolicking lamb. When it grows weary of this fast life it decides to settle down in some pleasant place near a pool of water, where it again takes up the ordinary routine of living.

Among human athletes we occasionally find skilled hoppers; plants, too, indulge in this form of athletics. The "Leap-in-the-field"-or "Windwitch," as it is sometimes called-if medals and badges were bestowed upon plant athletes, would hold in all probability a tremendous collection in recognition of its place as "world's champion" in the high-jump and in the hop-skip-and-jump. This curious leaper sends up numerous dry, slender shoots, like so many tiny arms, which reach around it, clasping hands, as playful babies would do, until the mother plant is encircled by hundreds of such cord-like binders. Sometimes these arms reach up three or four feet, and over and over they continue to bind until autumn comes on. Then the plant's vacation time has come. It withdraws its roots from the earth, shrinks together its folded arms until it is almost the shape of a ball, loses all its moisture and becomes dry as dust and light as a feather. Then comes the wind, and with the first puff, away it hops and tumbles, seeking here and there to join hands with its neighbours, who 


\section{PLANTS THAT ARE ATHLETES 77}

also wish to travel, until often dozens of these adventurous wind-witches rise together hundreds of feet in the air. Sometimes they whirl like dancing mice, and the whole massive, yet airy, ball seems to be a spirited, living thing. Not uncommonly it circles from the earth in the form of a crown or wreath, which the wind places on the head of some lofty mountain. No wonder the plant is named wind-witch. This marvellous method of sowing its seeds assures an ever bountiful supply of these witches; and they play havoc with the farmer's crops!

The American tumble-weed (Amaranthus albus), also several grasses, especially the common peppergrass, has this hopping habit developed to a remarkable degree. Another example of a skilled hopping athlete is the evening primrose. When this plant dries up, it is soon pulled from the ground by the nagging wind. Sometimes its branches break in such a way that they give the impression of a number of crutches, by means of which it hops and limps over the prairies, like an aged cripple trying to get away from a storm. This is its ingenious way of sowing its seeds; and yet many people have never observed even the beauty and wonder of its flowers, not to mention the novel manner in which 


\section{THE HUMAN SIDE OF PLANTS}

it travels in the fall! Very true are the poet's words :
"A primrose by the river's brim, A yellow primrose was to him- And it was nothing more!"

There are plants which can tie sailor's knots! The Virginia knotweed was skilled in this art long before man had even heard of it. The knotweed is a first cousin to the common knot-grass, and also to the prince's-feather. The tiny flowers of the knotweed are held on a long, club-like stalk, at the base of which is a joint, that well represents a sailor's knot. When the seeds of this plant are ripe, the pods containing them, which form the knots, dry rapidly and shrink. As this shrinking continues, the knot at last yields to the strain and snaps apart -hurling the seeds out and away, to germinate in places far from the parent plant. This action is much like the motion of the small boy with his sling-shot.

The capsules of several of the violets have a strange, mechanical movement of the valves by means of which they actually shoot their seeds, often to a distance of several inches from the parent plant. While the seeds are ripening, the pod droops its head until it is hidden beneath the leaves; but, as soon as the seeds are fully developed and ready 


\section{PLANTS THAT ARE ATHLETES 79}

to be scattered abroad, the stem holding the pod becomes erect, the pod itself raises its head until it is level with or above the leaves, when it divides itself into three valves, laying them back horizontally so that the seeds may not fall out; and then begins the process of shooting. As the hard, dry edge of the valve contracts it presses the under side of the outer row of seeds; they, in turn, pressing on the middle rows. As fast as one seed is projected another rolls down and takes its place, the hard edges of the valve often curling together to force out the last remaining one. By this mechanical expulsion of its seeds the violet is enabled to secure a wide distribution of its species. It need have no fear of its seeds falling so close about the parent plant that all will be crowded, and so die for lack of air and sunshine and nourishment from the earth.

There are numerous other kinds of gunners and archers among the plants, and, just as with man, their guns or projectors and their manner of shooting are widely different. The common yellow oxalis or "sheep sorrel" has developed the shooting-habit to a wonderful degree. Its tiny seeds are covered with thin, skin-like bands that act, when touched, like elastics on a sling-shot, by suddenly curling up with sufficient force to shoot the tiny 


\section{THE HUMAN SIDE OF PLANTS}

seeds a considerable distance. This movement is as quick as a flash of lightning, and the seed-pod is usually turned inside out. The oxalis holds its seed-pods erect, daring any one to touch them! And if one does, away shoot the seeds to a new home where they will germinate and grow as new plants. This is their only method of getting away from home; if they did not shoot out into the world, they would continue to sow their seeds in the same place until they would crowd each other out.

The witch-hazel, touch-me-not, squirting cucumber, balsam, wild geranium, peas and vetches, mustard, and castor bean-all these send their children into the world by shooting or squirting them far from the parent plant. Some of these fruits act as regular sling-shots, hurling their seeds sometimes, as in the case of the witch-hazel, twenty to twenty-five feet; others, like the balsam vine and the squirting cucumber, act like a squirting gun; while the touch-me-not, when touched or shaken, suddenly twists back, and shoots its seeds out with such force that they rattle like bird-shot among the dead leaves. Observe the fruit-pods of beans and peas, especially when they are first exposed to a dry atmosphere, and this wonderful shooting phenomenon will soon be apparent. Or collect some 


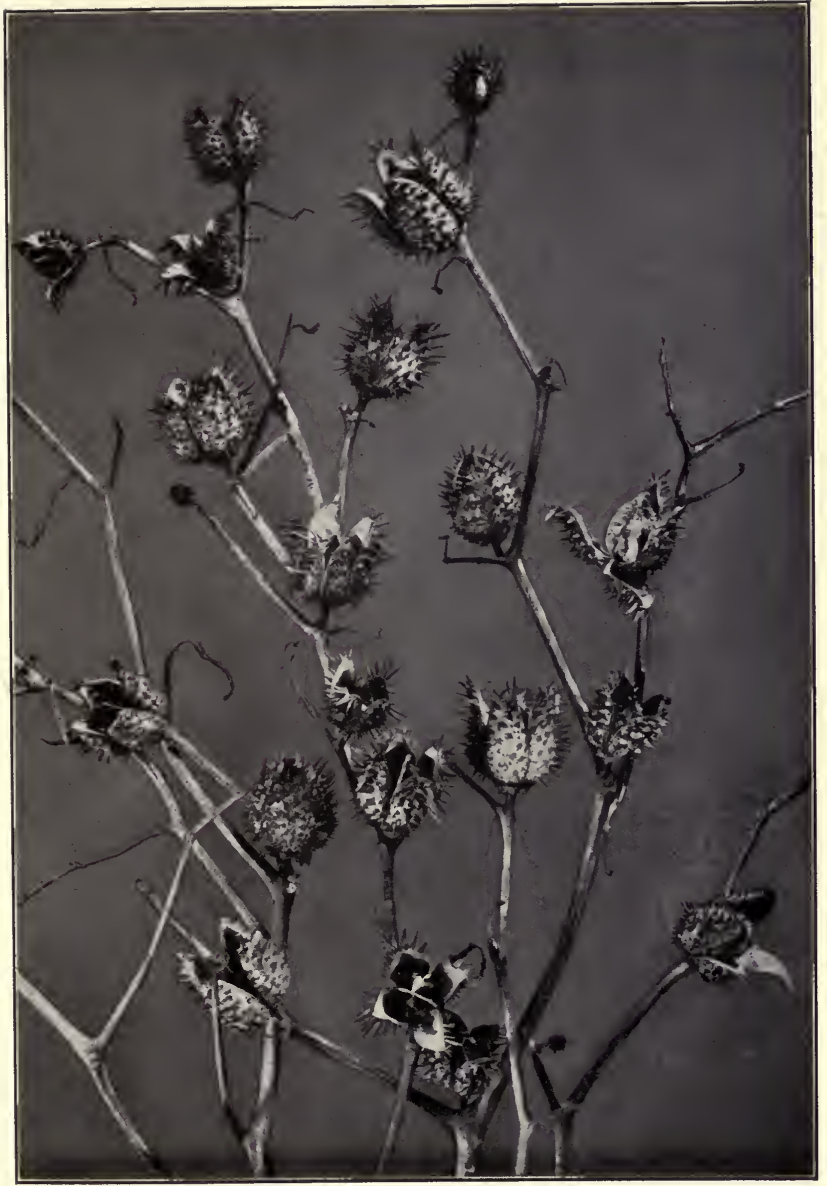

JIMSON-WEED. Datura Stramonium.

Unlike most plant athletes, this retains a portion of its seeds for spring sowing. 


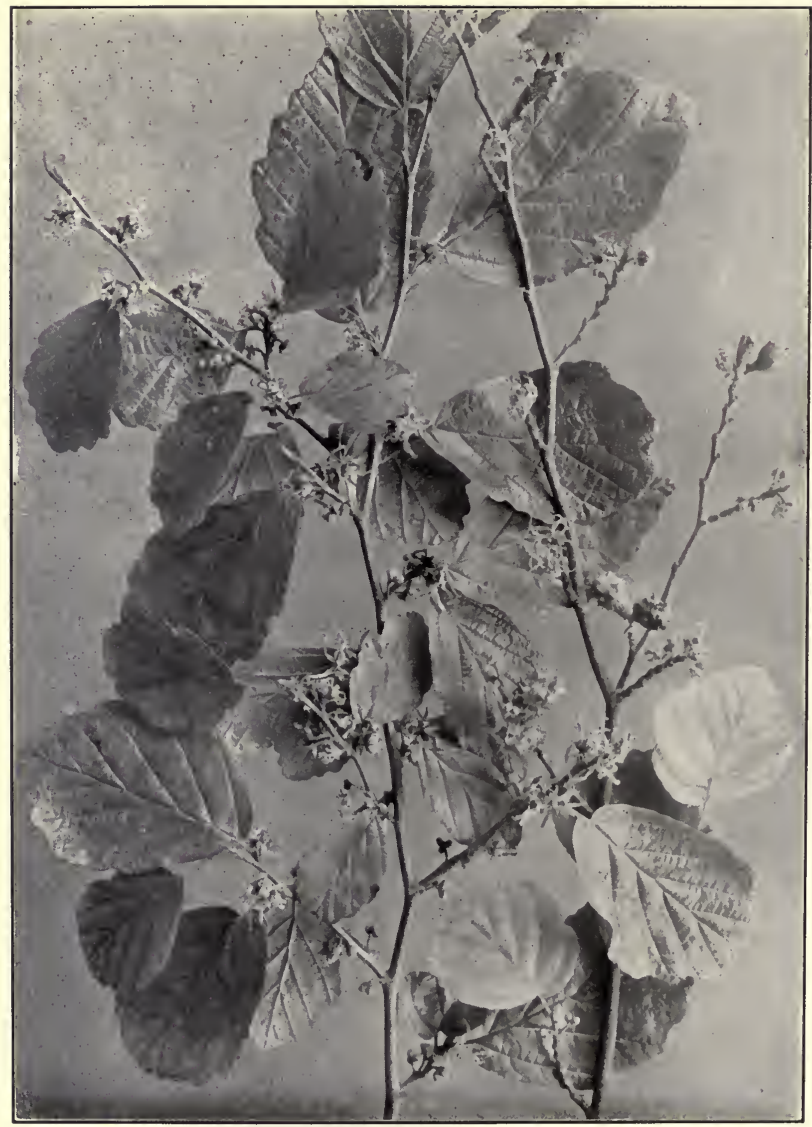

WITCH-HAZEL. II amamelis Virginica.

- This skilled athlete hurls its seeds for twenty to twenty-five feet. 


\section{PLANTS THAT ARE ATHLETES 81}

branches of the witch-hazel and keep them in a vase for a few days.

There are many skilled aeronauts among the plant athletes. They have been working and experimenting for ages in perfecting their magnificent airships. So skilled are they and so far advanced in the art of flying, that their balloons, kites, parachutes, and airships are being studied and imitated by man. These unique airships are designed with marvellous skill. Among the dandelions, goldenrods, asters, and thistles, are, perhaps, the most perfectly devised airships. When the tiny seeds of these plants are ready to go out into the world, each has a ship of its own by means of which it may navigate the air.

The fruits of the maple, elm, pine, and ash are prepared for sailing from high elevations-the tree-tops. They do not, as a usual thing, travel for very long distances, but are apt to light fairly near the parent tree. Thus these trees are quite often found in large groups, like the pine forests. The fruit of the elm is placed in the centre of its airship, and as it floats to the ground it seems to hesitate before alighting, like a butterfly, or an insect-hunting sparrow, as though it were trying to decide if this were a choice spot for landing.

There are certain airship plants, like the bladder- 


\section{THE HUMAN SIDE OF PLANTS}

nut, which live near the water's edge, and their balloons are likely to be lost at sea unless some special provision is made to save the children in case the balloon falls into the water. To this end they have made their three gas compartments, each of which carries a tiny sailor, safely guarded in an air-tight room; and, if by chance the bladdernut grows tired of sailing in the air, it may easily light in the water, and glide along as smoothly as a water-fowl or a man-made hydroplane.

The children of the linden travel by means of a kite-like appendage, which may be used as a lifepreserver in case the seed falls into the water. The narrow-leafed dock, another plant which grows near the water, carries a life-preserver attached to its seeds. If for any reason the seeds become separated from their preservers, they immediately sink beneath the water and are lost.

Many of the grasses and sedges travel by means of boats, canoes, and rafts. In the genus Carex, the fruit grows in a tiny canoe; and many the craft that silently lands its happy passenger in a place of safety! In the arrowhead, the cat-tail flag, buttercups, and cinquefoil, there is always some form of sail, boat, canoe, or raft, by which the seeds may be saved from shipwreck. These life-preservers are usually in the form of woody or paper-like ap- 


\section{PLANTS THAT ARE ATHLETES 83}

pendages, often growing from the pointed end of the seed.

It is not uncommon to find plants sailing in the water that are supposed to travel only in the air; for example the milkweeds can easily use their airship equipment as sails in the water. These sails have no difficulty in propelling the flat-margined seeds. Occasionally a number of the hairy sails become free from their seeds and form a sort of drifting raft for other tiny seeds that may have caught on to them.

Some small plants, like the bulblets of the wild garlic, actually float or swim while growing. It is small wonder that they are so widely distributed.

In the north, where the snow covers the earth for a large part of the year, it often happens that a thin coating of ice forms on top of the snow. This coating is very slippery, and makes an excellent skating ground for small seeds. And these seeds are ever ready to take advantage of a trip across the ice. They rise with a puff of the wind, alight on the ice, and skate or float to their destination. Away they go, like happy children, out for a winter frolic.

Many of these plants, like the prickly pigweed, and lamb's-quarter, have prepared their children for these winter sports long before they have a chance 


\section{THE HUMAN SIDE OF PLANTS}

to go; so the tiny seeds have to wait, just as other children, for the ice to freeze over before they can skate. The mother plant has had to hold her arms, or branches, which bear the children, carefully above the snow until the ice has become right. Then along comes a bunch of hungry little birds who, in their efforts to get the seeds for food, scatter them upon the snow and ice. But not all of these seeds skate. Some prefer to play in the snow, digging a house in a big snowdrift and soon becoming covered up, where they must sleep till the warm sunshine melts the snow and releases them.

Some plants, like the common locust, make iceboats by means of their long pods, which have fallen to the ground and burst open. There are always an equal number of seeds clinging to each side, gleefully begging to be taken for a sleigh ride across the icy fields; and they do not have long to wait. Along comes the kind wind, and away the pod-sleighs go, rattling over the snow and ice. Some of the seeds drop off on the hill top, others travel to the valley below; and still others cling to the boat, as though they were fearful of going out into the great world. But each of the locust's seeds is well clothed and protected. They are very hard, and their parent tree has so coloured them that they are not easily seen by hungry birds. 


\section{PLANTS THAT ARE ATHLETES 85}

Not the least among the various sports of plants is dancing. Since the earliest times dancing has been associated with flowers. To such an extent is this true that among the old Egyptians even their religious dances were carried out largely by means of garlands. There is a comparatively modern Egyptian dance called "The Bee" in which there are numerous wreaths of flowers. The weird dances of the East Africans also were aided by flowers. How often in literature do we see reference to dancing flowers, such as "the dancing Columbine"! A strange plant of the East Indies, known to botanists as Mantisia saltoria, has gained for itself the name of "Dancing Girls." This is, no doubt, due to its supposed resemblance to a woman. The name saltoria is derived from the Latin word meaning a dancer.

There are some strange seeds known as "Mexican jumping beans." These seeds are the fruit of a small shrub which grows in Mexico, Central and South America. The seeds are triangular in shape, and for about six months they are continually jumping and jerking, or rolling from side to side. This lively movement is caused by a fat little worm which inhabits each bean. As the worm grows he cuts a door in his bean house and spins over it a portière of silk; then he curls up for his last sleep; 


\section{THE HUMAN SIDE OF PLANTS}

and when he wakes he pushes his way through the door and sails out into the world, a tiny grey moth.

There is one form of athletics in which the gymnast or "outdoor man" of to-day does not indulge to a great extent, although for his general development the pursuit of this kind of exercise with more avidity would be beneficial. This is climbing. If we are to accept the theories of Darwin, we must believe that climbing was more than a popular sport for our ancestors; and certainly the instinctive inclination of children toward this effort would seem to point to some inherited suggestion or leaning in the direction of this form of exercise.

In plant life we find instances of climbers so numerous as to indicate the most popular of all the forms of athletics pursued by the plants. However, there are radical differences in the methods of climbing followed by different plants. The Virginia creeper, for instance, forms little sticky feet at the ends of its tendrils; and in climbing, all the tendrils, sensitive to the light and darkness, seek out the dark nooks and crevices in preference to the light places, and, clinging there, enable the plant to mount to the top of the support. The bryony, on the contrary, catches at anything that will afford a means of tenability, preferring the light to the darkness, and therefore tending toward 


\section{PLANTS THAT ARE ATHLETES 87}

the lighter side or portion of the object upon which it climbs.

The American wistaria (Kraunhia frutescens) is one of the most popular of climbing athletes. It is commonly found in the South and West where its blossoms form a veritable canopy of purple over the porches and trees in the early spring. Later, when its leaves are fully developed, its boughs are a favourite nesting place for mocking-birds. The wistaria sometimes grows to the enormous height of sixty feet, its grey stems looking not unlike twisted wooden arms reaching upward.

Yellow jessamine (Gelsemium sempervirens) is perhaps the most typical of all American twiners. The genus has only this single species, and no very near relatives outside of the American continent. The vine has small, willow-like leaves, and is usually classed as an evergreen, but it has been known to shed its leaves at intervals.

This interesting climber blossoms among the earliest flowers of spring. It is not uncommon to find it in full bloom in January, especially in Texas and Florida; and in March, Alabama and Mississippi are filled with its fragrance. It delights in climbing over bushes and shrubs, and often its delicate yellow flowers may be seen in great pro- 


\section{THE HUMAN SIDE OF PLANTS}

fusion swinging from the boughs of pine-trees forty to fifty feet in the air.

Perhaps the greatest charm of the yellow jessamine is not its athletic prowess as a climber, nor the beauty of its golden flowers, but its marvellous perfume!

"The perfume from the blossom's cell, On every zephyr stealing."

Yet it is a plant of many notions and moods, and as a result it is often found entirely devoid of perfume. A strange trait indeed, for a plant famed for its delightful fragrance!

An interesting error has arisen regarding the name of this climber. While it is commonly known in the South as "jasmine," it is not botanically related to the genus Jasminum, or the true jasmines. "Jasminum" probably came from the Arabic name of the plant, "jasmin."

But, whatever the origin of its name, the yellow jessamine is enthroned forever in the minds of those who have been fortunate enough to see it in all its glory of golden perfumed blossoms joyously proclaiming to the world, "Spring has come!"

The plant which climbs eternally, always straining toward the light, shows in its glossy leaves or its gorgeous blossoms and in its long natural term 


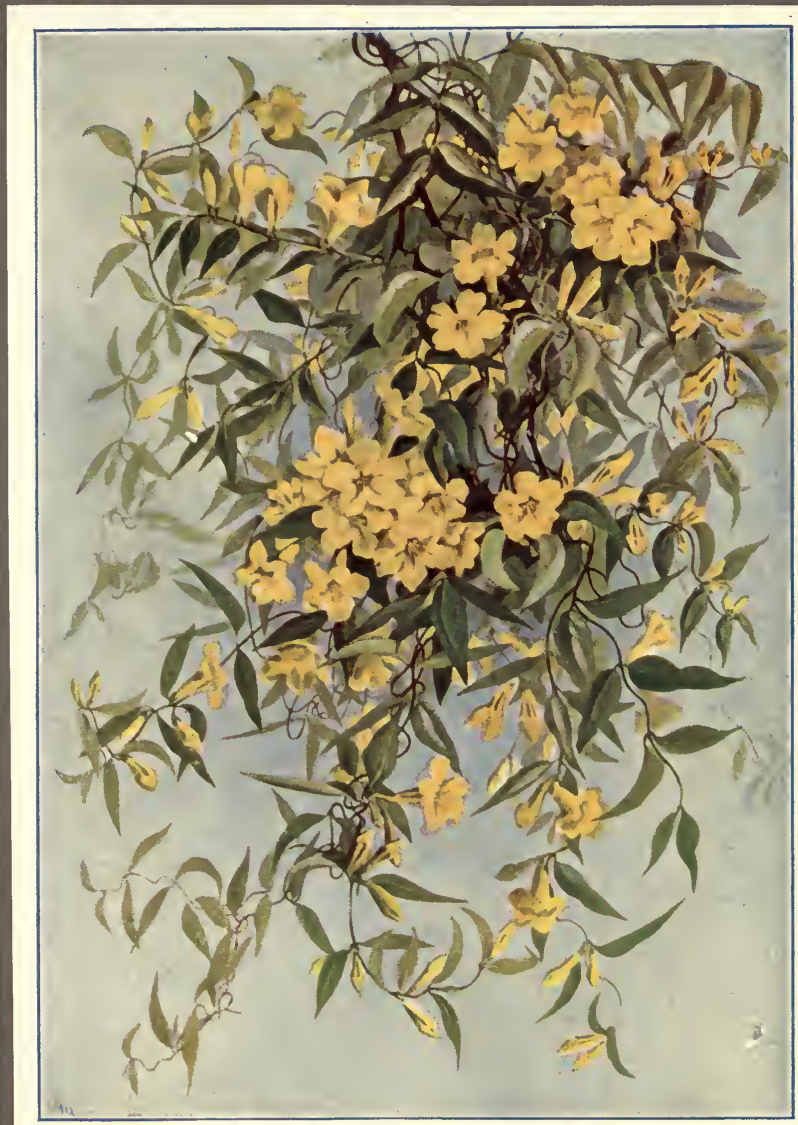

YEIILW JESSAMINE. Gelsemium sempervirens.

An athlete that climbs vigorously ove: tree and fence, filling the air with the perfume of its blossoms. 



\section{PLANTS THAT ARE ATHLETES 89}

of life the good it has drawn from this climbing habit. There is a high development of courage and will, as well as of physical power, toward which the persistent climber makes a marked advance. 


\section{IX}

PLANTS THAT RIDE ON ANIMALS

THERE are many kinds of plants that seem 1 to desire to go out into the great world and accomplish something but have no plumes nor wings, nor airships, such as the dandelion possesses, by which they may fly. Their children are not shot into the world, as are those of the oxalis; they have not the power of the squirting cucumber; they can not roll and tumble, like the Rose of Jericho; nor can they float to a safe destination, like the cocoanut; they cannot walk, as do many of the ferns and grasses; nor do they have the beauty to attract birds and animals, as do the cherries and plums; yet they grow tired of staying in one place and must, like other plants and animals, find a way whereby they may travel into the big world. Their seeds must be distributed in new soils and various places suitable for their best development; and this they do by the simple method of taking a ride! And many and varied are their beasts of burden.

Some stick to the feet and wings of birds and 
thus travel around; others ride in the water attached to fish that may happen to swim their way; still others watch for insects on which they may steal a ride; but a favourite device with many is to ride on animals, or even people.

The kinds of plants which ride on animals must be able to catch hold of the animal as he passes by, or stops to graze, as a boy "hops" a passing car. To this end, plants which travel on animals have many clever tricks whereby they may catch and cling to the passer. Some carry a diversity of hooks, claws, and grapnels. Some have developed certain shapes and devices for clinging; others have formed the most fantastic and demoniacal methods of holding on to the unfortunate animal to which they have attached themselves.

Among the simpler clingers is the common burdock. The seeds of this plant are very troublesome, and have become so well adapted to travelling by using the peculiar, tiny hooks or claws which aid them to cling, that they are very widely distributed over the earth. They mount the tails of horses and cows, cling to the fleeces of sheep and goats; and sometimes even steal a ride on a Jack-rabbit! Burrs of this type are filled with large seeds, and they remain attached to the animal until they find a suitable home or place to live, when they drop to the 


\section{THE HUMAN SIDE OF PLANTS}

ground soon to germinate and spring into new plants.

Another kind of clinger is the cockle-bur. These burrs also are covered with tiny sharp hooks, which are terrible indeed when embedded in the skin of animals, for they are almost impossible to shake off or pick loose. These plants frequent pasture lands and the burrs are especially prone to ride on horses' tails.

Still another clinger is the sand-spur, which grows abundantly in open fields and in dry desert places of America. The spurs are the seeds of a peculiar form of sand-loving grass; and when once they get a start in a new region it is practically impossible to free the land of them. These spurs attach themselves to animals, and of ten lacerate their flesh; sometimes they so completely cover the feet of dogs, or even of children, that it is impossible for them to walk until the spurs are removed. Occasionally the seeds fasten themselves in an animal's mouth, causing it to suffer severe pain; they often attach themselves to the beaks of doves and various prairie birds.

Every one has possibly seen the stick-tightsor has acted as their unwelcome beast of burden! How harmless the little akenes (seed-pods) with their tiny spiked horns appear! All the summer 
the parent plant has been preparing her babies for their autumn trip. At last their dainty brown travelling suits, all trimmed with sharp-pointed hooks, are finished; and every little hook or finger is ready to cling to the first passer-by, horse or cow, boy or girl, man or woman. For they have never been away from home before, and, like anxious children, they naturally wish to ride out into the big world! At last along rush a number of schoolboys on their outing. Seizing their opportunity, the tiny akenes catch hold of the boys' trousers, and over the hills they ride, until time for the boys' luncheon, when they are picked off the trousers and left many miles from their former homes, where they will take up their residence and start a new patch of stick-tights.

Among the numerous kinds of seeds-such as those of strawberries, blackberries, gooseberries, cranberries, grapes, and currants-which are largely distributed by birds which eat them, it is not uncommon for seeds to attach themselves to the feet and feathers of birds, and thus ride away to a suitable place of abode. However, this is not so common a method of travelling as that of clinging by means of hooks.

There grows in the United States a very weird looking fruit, known to botanists as the Martynia 


\section{THE HUMAN SIDE OF PLANTS}

proboscidea, which has two backward-curving horns, from one and one-half to three inches long, strikingly like miniature buffalo horns. These are very tough and hard, and the two grapples curve in toward their base, forming a half-completed circle, which is peculiarly adapted to catching on to the feet of cattle, sheep, and goats, and occasionally hogs. This strange plant is often referred to in writings as the unicorn-plant. It is largely cultivated for its fruit in many parts of the country, but in some places it is a very unwelcome guest.

Of all horrible, uncanny, and fiendishly wicked plants, the South African grapple-plant has no rival. The very thought of its diabolical ways is enough to make one shudder. It is worse than the Murderer Liana that strangles its victim to death; and it uses the same unscrupulous tyranny and injustice that we might expect to find among the lowest and most uncivilised savages. Nearly all African travellers have mentioned its murderous habits; Dr. Livingstone says: "It has so many hooked thorns as to cling most tenaciously to any animal to which it may become attached. When it happens to lay hold of the mouth of an ox, the animal stands and roars with a sense of pain and helplessness. The fruits when dry are hard and 
bony, the fleshy or pulpy matter being dried up or absent. They have thus the appearance of huge long-legged spiders. The thorns or hooks are exceedingly sharped and recurved, lacerating the flesh and tearing the clothes fearfully when they have become attached. These spines are merely natural prolongations; the flowers are of a rich crimson and purple colour; the corolla is tubular and somewhat of the shape of the foxglove; the calyx is fiveparted; and the fruit contains a number of peculiarly wrinkled seeds."

It is claimed that the fruits of this plant sometimes bring death to so powerful an animal as the royal lion. If while rolling about on the dry plains they attach themselves to the lion's skin, in trying to get them out he often gets them into his mouth and as a result perishes in great agony.

The number of plants whose seeds ride on animals is very large; but there are some more progressive-or more fortunate - than their neighbours who do their travelling by means of the railroads; some even take long steamboat journeys. Seeds of various kinds, like the grasses and sedges, clovers, and flax, often ride to regions uninhabited by their kind in the bedding or litter of stock cars. When the cars arrive at the stock-yards they are unloaded but seldom cleaned; instead, they are sent with their 


\section{THE HUMAN SIDE OF PLANTS}

cargo and passenger seeds to new shipping points. Here, if the new cargo demands clean cars, the dirt is swept out, and the seeds find new homes in lands probably hundreds of miles from their original starting place. Those that travel on boats usually are wind-blown seeds that cling to the clothing or baggage of passengers, or stow themselves away in miscellaneous corners of the cargo.

So these many unpopular plant-children do not sulk in a garden corner because they cannot walk, nor fly, nor climb, nor jump; their always-wise Mother Nature has fitted them to take much longer journeys in their own peculiar way of catching hold of and riding on animals. 


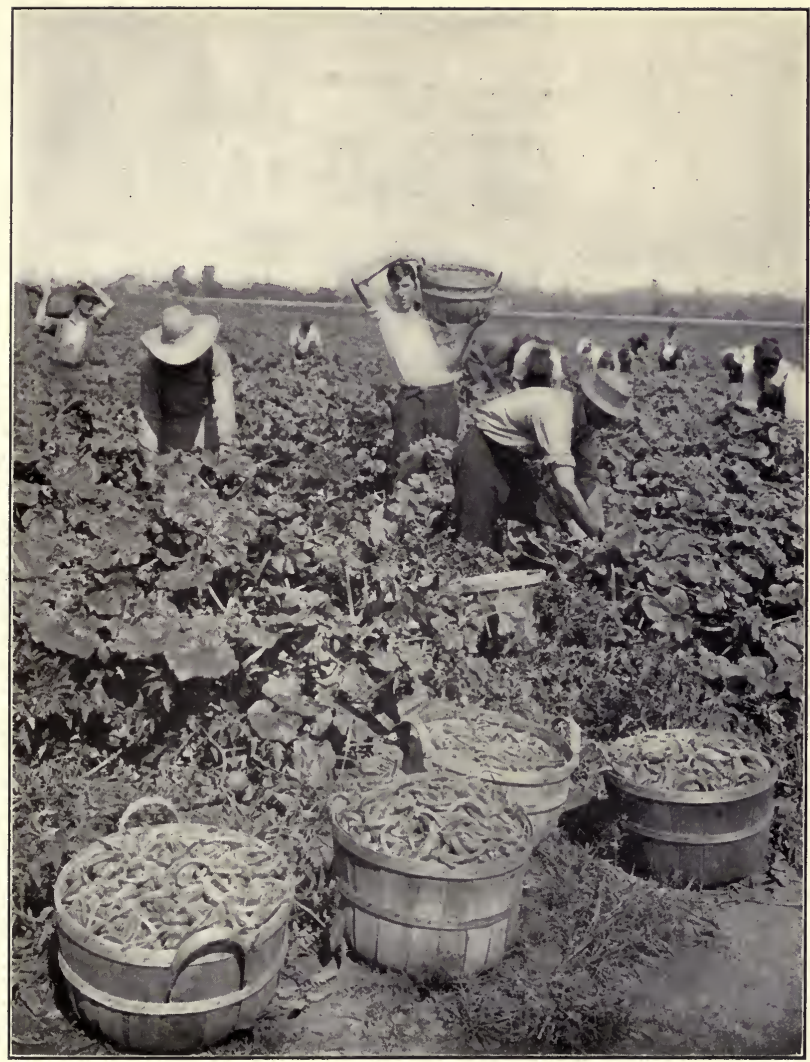

UNICORN-PLANT. Martynia proboscidea.

The cultivation of the unicorn-plant is becoming an important industry in the United States. 


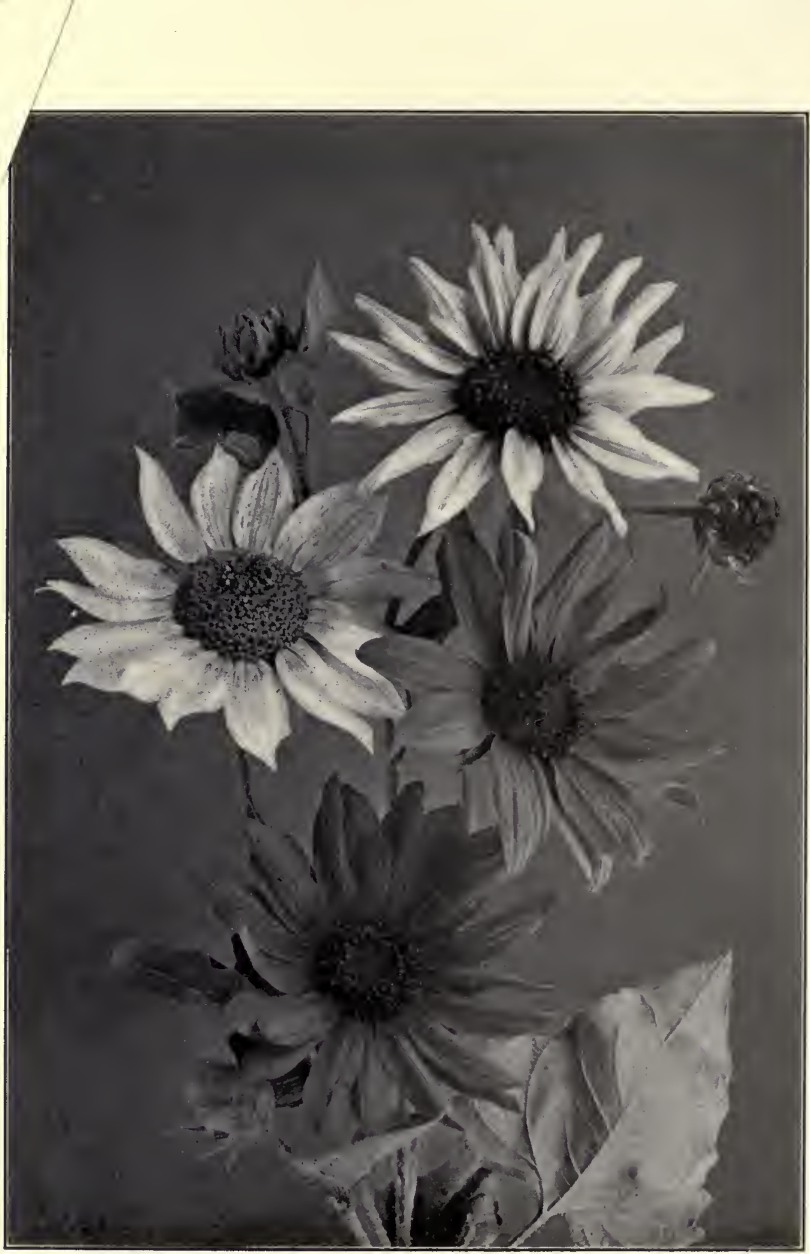

SUNFLOWER. Helianthus.

"The sunflower turns on her god when he sets The same look which she turned when he rose," 


\section{$\mathbf{X}$}

PLANTS THAT PREDICT THE WEATHER; COMPASS PLANTS; DAME NATURE'S ALMANAC

"Weak with a nice sense, the chaste Mimosa stands, From each rude touch rithdrawes her timid hands; Oft as light clouds o'erpass the summer glade, Alarmed she trembles at the moving shade, And feels alive through all her tender form The whispered murmurs of the gathering storm; Shuts her sweet eyelids to the approaching night, And hails with freshened charms the rising light."

THE Weather Bureau Service saves annually and predictions. Day and night danger signals and warnings are sent out from the central office of this bureau to the utmost bounds of the land. In a very brief period warnings of the approach of a cyclone, a tornado, or a blizzard, may be wired to shipmasters of all parts that will be affected. Every form of warning that may save life and property is given against all weather dangers, from snowstorms to floods. In fruit-growing countries especially does the need of prophecy of sudden cold exist. 


\section{THE HUMAN SIDE OF PLANTS}

The scientific staff of the United States Weather Bureau is continually seeking to improve its efficiency, and there is little doubt that, at no distant date, it will adopt the novel and efficient method already in use in London, of forecasting the weather by means of the weather-plant (Abrus precatorius). A number of scientists believe that by means of this augural plant it will be comparatively easy to predict cyclones, hurricanes, tornadoes, earthquakes, and even volcanic eruptions.

Botanists have long been aware of the fact that by close observation of the leaves of this plantprophet the condition of the weather may be correctly foreshown. This plant is so keenly sensitive to all forms of electrical and magnetic influences that even the slightest change in temperature is immediately discernible by the movement of the leaves of the plant, whose prophetic qualities were first brought into prominence by an Austrian baron, Professor Nowack. His discoveries were made known to the public about twenty-five years ago, when specimens of the plant were shown and weather predictions made for two days in advance. Se very accurate were most of these forecasts, that not only botanists but the leading scientific thinkers of the world became interested. Both Germany and Austria took up the matter; and 


\section{PLANTS PREDICT WEATHER 99}

later, through the courtesy of King Edward VII, who was then Prince of Wales, Prof. Nowack went to England and continued his interesting experiments at the Kew Gardens.

While at Kew the sensitive weather-plant enabled him to predict a number of electrical disturbances before they were in evidence, in addition to the famous fire-damp explosion in which many lives were lost. He established a Weather-plant Observatory at Kew, and since then he has travelled extensively and has made a tremendous collection of weather-plants, some of which have been sent to the New York Botanical Gardens.

This interesting weather-plant, or "Indian licorice," of which so little is known, has small leaves, not unlike a rose, which are constantly moving. The people of India hold it in great esteem, making beads out of its small, curiously egg-shaped seeds. These are known as "John Crow beads" and are bright scarlet, dotted with black spots, strikingly similar to certain poisonous spiders of the tropics. They are made into necklaces, and are used for rosaries-the name "precatorius" means prayer. The seeds are used also as standards of weight; it is generally known that the weight of the famous Kohinoor diamond was determined by them.

But the ability to foretell weather conditions is 


\section{THE HUMAN SIDE OF PLANTS}

only one of the remarkable powers which are known to exist in plants. There can be no question that there also exists in plant life a well-balanced sense of time and direction. Many, many times throughout the writings of the poets we find references which concede such powers to different plants. Longfellow tells of the compass-plant, in these beautiful lines from "Evangeline":

"Look at this delicate plant that lifts its head from the meadow,

See how its leaves * all point to the north, as true as the magnet;

It is the compass-flower, that the finger of God has suspended Here on its fragile stalk, to direct the traveller's journey Over the sea-like, pathless, limitless waste of the desert."

As a guide to the traveller perhaps the best known natural compass is the bark of trees. Natives of the woods know that the north or shaded side of the tree is usually coated with the green of moss; and, by this and other prominent markings of direction, they find their way through the apparently pathless forest.

The sunflower is truly named! Not only does it radiate the golden colour of the sun, but it always

* The flower of the compass-plant, not the leaf, is the indicator of direction, from which the plant receives its name; although the leaf does usually, not always, have its edges point north and south. 


\section{PLANTS PREDICT WEATHER 101}

points toward its god, and is second only to the compass-plant as a floral compass.

Sunflower farming is common in many parts of the world-especially is this true in Russia, where in the present generation the sunflower has become a prominent product of most of the farms. It is extensively used for food, the seeds being crushed and made into a coarse bread; it makes excellent fuel; and it is cultivated also for its oil. The fact that it does not exhaust the soil where it grows but, on the other hand, actually enriches it, makes it an invaluable product.

In addition to the weather-prophet and way-finding plants, Nature has her almanac, whose pages are illustrated with dainty pinks and blues, with brilliant reds and oranges, with stately purples.

To the lover of the fields and woods, the artificial reckoners of time and events that are in common use by mankind become largely superficial means to ends already attained through the more sweet and graceful guides provided by Dame Nature. Certainly the times and seasons are recognisable by the decorations and carpetings of woodland and meadow. This is a generally accepted fact. Hardly realising the definite action, we all assign to the different seasons their own atmos- 


\section{THE HUMAN SIDE OF PLANTS}

phere. We say the air "smells like spring," it is a "regular autumn day," and so forth, conceding in these statements to each of the seasons certain definite conditions which appeal to enough of the senses to create an "atmosphere." And unquestionably to no sense is the appeal of the season more direct than to the sight. Thoreau showed his recognition of this when he claimed that if he were put to sleep in a swamp, he could tell the time of year by the plants that bloomed about him.

There is an association of certain colours with each of the seasons, which must be appreciated when flowers are considered in the order of their annual bloom.

In the spring, the childhood of the year, the delicate or "baby" colours predominate; soft blues, dainty pinks, and pretty yellows being especially in evidence. There are the tiny forget-me-nots, blue violets, and bluets; the yellow jonquils, cowslips, buttercups, and dandelions; and the sweet trailing arbutus, and the redbud, a charming pink blossom that fills the woods of the South during the spring months.

As the summer months draw on, the character development of the year's flowers becomes apparent in the strengthening of their tones. The pink of spring becomes the red of June roses, and intro- 


\section{PLANTS PREDICT WEATHER 103}

duces the rule of red and white. Then the soft tones draw timidly back into shaded glens, while the blazing summer sun brings out the strength of the glorious red field poppy, the trumpet-flower, the red lobelia, as contrasted to the white fields of clover, daisies, and mayweed.

Red and white hold sway until August, proclaiming the onrushing fall, introduces the autumn styles; then the reds soften to royal purple and the whites yield to their regal golden successors. The purple asters, verbenas, and mints, together with the blazing goldenrod and the yellow evening-primrose, crown the year with a royal robe of purple and gold, the mantle of autumn, and the imperial proclamation of the Harvest Season.

The winter has, in its turn, a distinct group of tones which we associate with the season, although these are not gained from any floral bloom of the time. The dark green of the evergreen and the brilliant red of the few lingering berries; the browns of earth, field, and highway; and the soft white of the fallen snow, are synonymous with winter, and must therefore be acknowledged as her "seasonal tones" in Dame Nature's almanac. 


\section{XI}

PLANTS THAT TELL THE TIME OF DAY; PLANTS THAT KEEP A DIARY

PLants can actually tell the time!

1 Certain plants open and close at definite hours of the day with such regularity that they can be, and have been, relied upon as timepieces. Unknowing persons have claimed that this is "due to the changes in temperature," but there is evident in plant life an understanding of periods of time which can be laid to no such cause as temperature. We are forced to believe that they have a knowledge of the hours of the day. There are some plants - the white or red water-lily, the proliferous pink, and the purple sandwort-which regularly open and close not only at definite hours but at definite minutes in those hours!

The idea of plants telling the time of day is not new. The Swedish botanist, Linnæus, realising this remarkable power of the plant, built himself a floral clock which should, by the hours and minutes of the opening and closing of his plants, indicate 
the time of day. Nor was the scheme original with Linnæus, for, although to him is given the credit for this idea, there is a passage in Marvell's poem, "The Garden," which tells the story of another who had planned his flower clock before ever Linnæus saw the light of day:

\begin{abstract}
"How well the skilful gardener drew, Of flowers and herbs, this dial knew! Where, from above, the milder sun, Does through a fragrant Zodiac run, And, as it works, the industrious bee Computes its time as well as we.
\end{abstract}

How could such sweet and wholesome hours Be reckoned but with herbs and flowers!"

Any one whose childhood has been spent in the woods and fields of the countryside will recall the familiar name of the common goat's-beard, "Go-tobed-at-noon." But there is no hour in the day that has not some flower to mark it!

Beginning long before the sun, we find the goat's-beard opening between the hours of three and five in the morning. Promptly at four, the lateflowering dandelion opens; while at various minutes between four and five at least three plants, the hawkweed picris, Alpine hawk's-beard, and wild succory, awake to greet the first rays of the morning sun.

At five, usually with the striking of the hour, 


\section{THE HUMAN SIDE OF PLANTS}

open the naked-stalked poppy, the copper-coloured day-lily, the smooth sow-thistle, and the blue-flowered sow-thistle; while within the following minutes, until six, the morning-glory and the common nipplewort unfold.

The spotted cat's-ear, the major convolvulus, and the great water-lily, Victoria Regia, open between six and seven in the morning.

Directly following these, and at seven o'clock, come the African marigold and the garden lettuce; at eight the shepherd's weather-glass and the proliferous pink; and sharply at nine o'clock the field marigold awakes.

Between nine and ten in the morning come the purple sandwort, the creeping mallow, and the chickweed; at ten, one of the Mesembryanthemums; at eleven, the Star-of-Bethlehem; and at twelve, the ice-plant.

Noon sees the closing of the first flowers and begins the recording of the "negative" or closing time instead of the "positive" or opening hours; although there are plants, such as the four-o'clock, and the primroses, and also the night-bloomers, with their own regular times, which open after the noon hour.

The late-flowering dandelion, the hawkweed picris, the Alpine hawk's-beard, the blue-flowered 


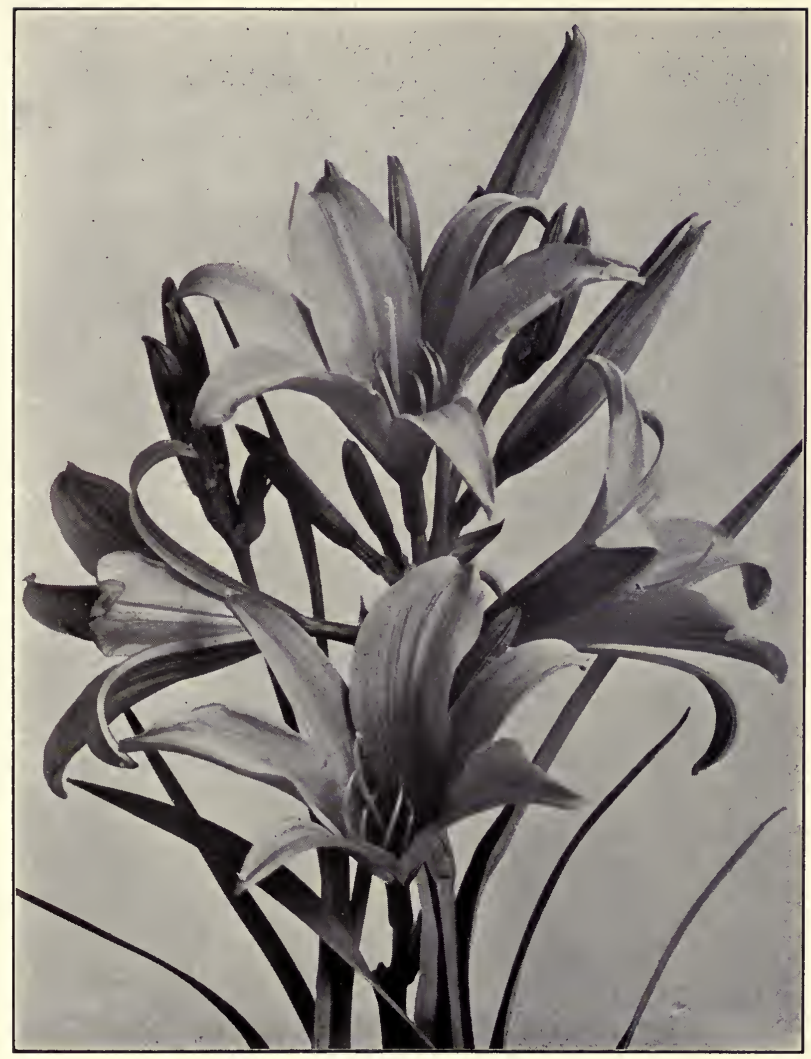

DAY LILY. Hemerocallis fulvc.

These showy flowers open at five in the morning and go to sleep between seven and eight in the evening. 


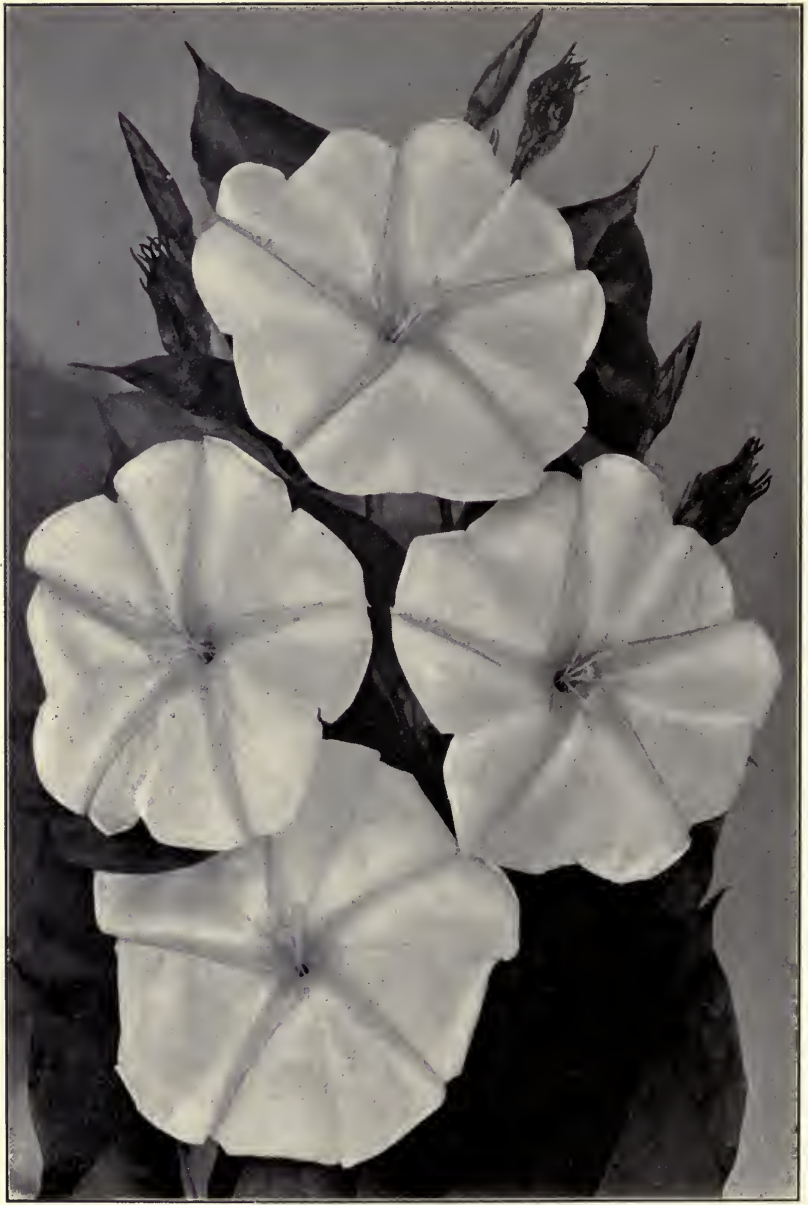

MOONFLOWER. Ipomøa Bona-nox.

The moonflower sleeps throughout the day but wakens regularly when night-time comes. 
sow-thistle, and the creeping mallow, close between twelve and one; between one and two, the proliferous pink; promptly at two, the mouse-ear hawkweed; and between two and three, the purple sandwort ends its day.

At three the field marigold closes; between three and four the African marigold; from four to five, the common morning-glory and the spotted cat'sear; and at five o'clock the Victoria Regia leaves her imperial white and golden throne and retires to the dainty, silken-walled, royal bedchamber.

At about six the common nasturtium, the field clover, and the garden acacia, fold up their tents. Promptly at seven the naked-stalked poppy ends its day; between seven and eight, the copper-coloured day-lily; from eight to nine, the wild succory; and the chickweed, from nine to ten.

From ten until five in the morning there are many night flowers, such as the fragrant nightblooming cereus, the ghostly moonflower, and the datura, to check off the hours and the minutes.

Was there ever a human being who at some time in his life did not try to keep a diary? There seems to be some divine instinct inborn in the nature of all living things which prompts the record of their actions. Were it not for this instinct 


\section{THE HUMAN SIDE OF PLANTS}

there would be no written history, and the advances or retreats of life would be retarded or stopped. All records are the results of this prompting; in all life it is evident. The same instinct that told the cave-man to cut his story into the rock surface prompts the small boy to whittle his initials on the top of his desk or on the old back fence. Each obeys an indefinable impulse; neither reasons in his act.

And as in animals and plants we find other visible forms of a universal nature, this purely natural instinct, appearing in the human type, appears in all types-if we can but discover it-in animal, bird, fish, and plant.

The bear makes his mark by rubbing high upon the bark of a tree. Is he conscious that he is leaving a record, a guide for other bears to aim for, to attain, and to supermark? Whether he realises this or not, the record is made, and other bears do strive to attain and supermark it; and incidentally in the striving become a better, hardier, greater race of bears.

So the dog makes his mark, the wild-cat his, and the lion his. The birds have their records; the fishes theirs; and, in concession to this requirement of universal nature, all plant life, from the tiniest fern to the hardiest monarch of the forest, makes 


\section{PLANTS THAT TELL TIME 109}

"and, departing, leaves behind it" a record for the instruction and inspiration of future generations.

The trunk of an alder is as truly an autobiography as are those written of themselves by the hands of men. And to one knowing and understanding the meanings of its various recording marks, the story is as clear as if recorded on the pages of a book.

For each year of its life the cross-section of a tree trunk shows a ring. This is the diary for that year. Is there a deep depression in one side of that fourth year's record? Perhaps a fallen log pressed against it there, temporarily hindering the tree's growth on that side. Do you notice that one side of the trunk is bulkier than the other? That is the southern side, where the warm sun by swelling the veins has correspondingly increased the thickness of growth. Look at the opposite side and you will see that the bark is thicker than on the southern side. The tree has clothed itself more warmly against the cold north winds than against the warm southern sun; and on this side too you will find an overcoat of green moss-an additional protection against cold.

How many times have we stood beneath some ancient tree and, looking up, cried hopelessly, "Oh, if you could only tell us what you have seen in all 


\section{THE HUMAN SIDE OF PLAN'TS}

your years of life!" But the tree is telling, telling much that we can understand; and who can say that it is not telling much more, its whole story, to those whose ears are attuned to its whisperings? We have learned to read many things that the plants have written; perhaps the time will come when there will be some soul, sufficiently unwarped by the artificialities of humanity, to open itself in all simplicity and naturalness to the communings of the plants, and so understand and interpret those myriads of unknown things, which they are striving to make us comprehend! 


\section{XII}

PLANTS THAT BUILD AIRSHIPS

MAN usually has been an imitator, a follower; seldom a creator or leader. Many of his marvellous inventions are patterned after the ingenious work of plants; and in no instance is this better illustrated than in the airship. Aerial navigation is indeed a new thing with him; with plants it is "older than the hills."

The desire for the welfare of their offspring has led plants to invent the most marvellous and ingenious methods for sending their children into the world. Plant children must not be sent out alone and unprotected, but must be well equipped to battle against unfavourable conditions and locate in desirable places. Perhaps overcrowding is the greatest danger to which they are subjected; and only as aeronauts have they solved their mightiest problem, many having successfully made various kinds of wings, balloons, and airships with which to send their children out into the world.

The uninitiated man is prone to look upon their 


\section{THE HUMAN SIDE OF PLANTS}

aerial navigation as a sort of chance or happening of no special importance; but it is vitally important, not only for the success of the plant, but for mankind as well.

Some plants send their seed-children out by means of spines and hooks, others shoot them out to places of safety, still others float upon the water, as the cocnanut; again some roll and tumble to a suitable home. All of these methods of dispersal are used; to say nothing of the work of birds and animals in aiding them to distribute the seeds in places where competition is not too strong, and where climatic conditions will be conducive to their best growth; but there is a large group of plants that have adopted by far the most ingenious method of sending their children into the world-that is, by means of airships. Plants of this kind may be grouped into several classes according to their method of navigating the air.

The seed-children of the elm-tree and those of the maple and the ash have wings-like Icarus of old-and fly somewhat like birds; those of the hoptree are surrounded by a peculiar kite-like structure with the seed in the centre of this thin membrane; the sycamore keeps its children. snugly rolled together in a ball until they are fully developed, when each one flies forth by means of a winged-arm 


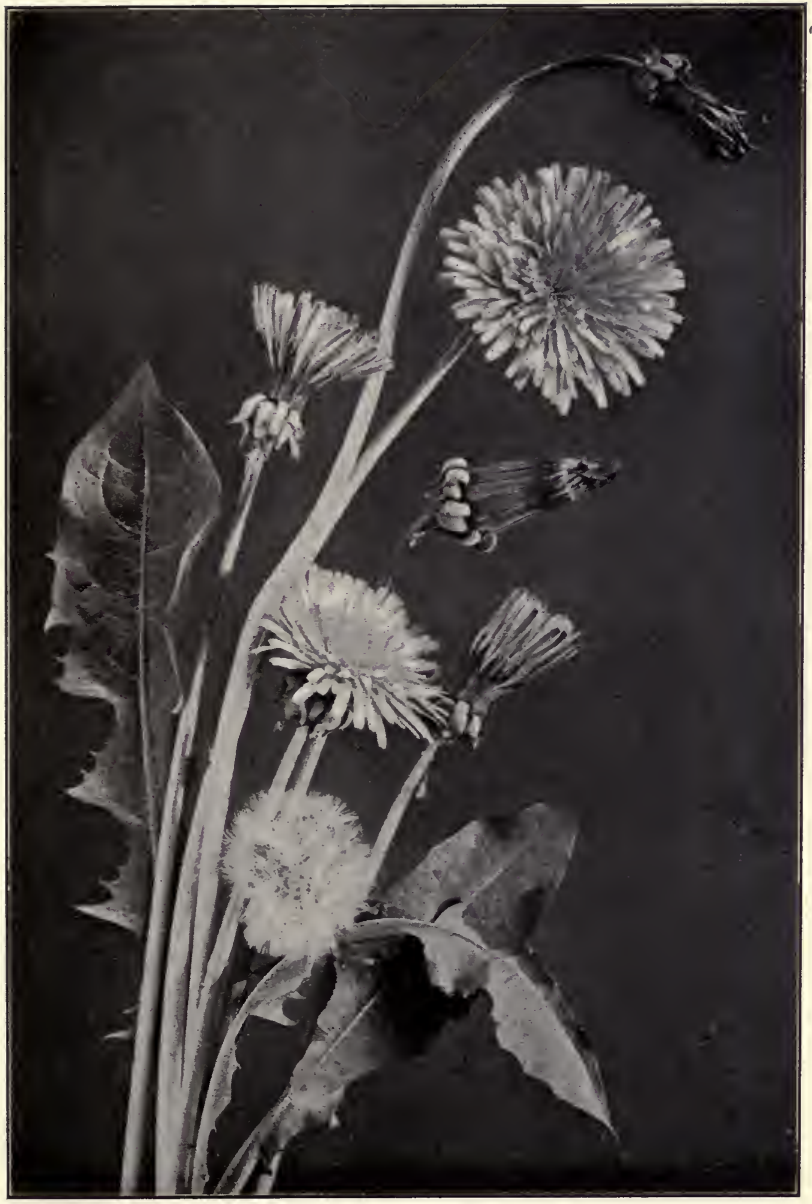

DANDELION. Taraxacum officinale.

The mother-plant presents each seed with a fairy-like balloon, that it may sail far from home. 


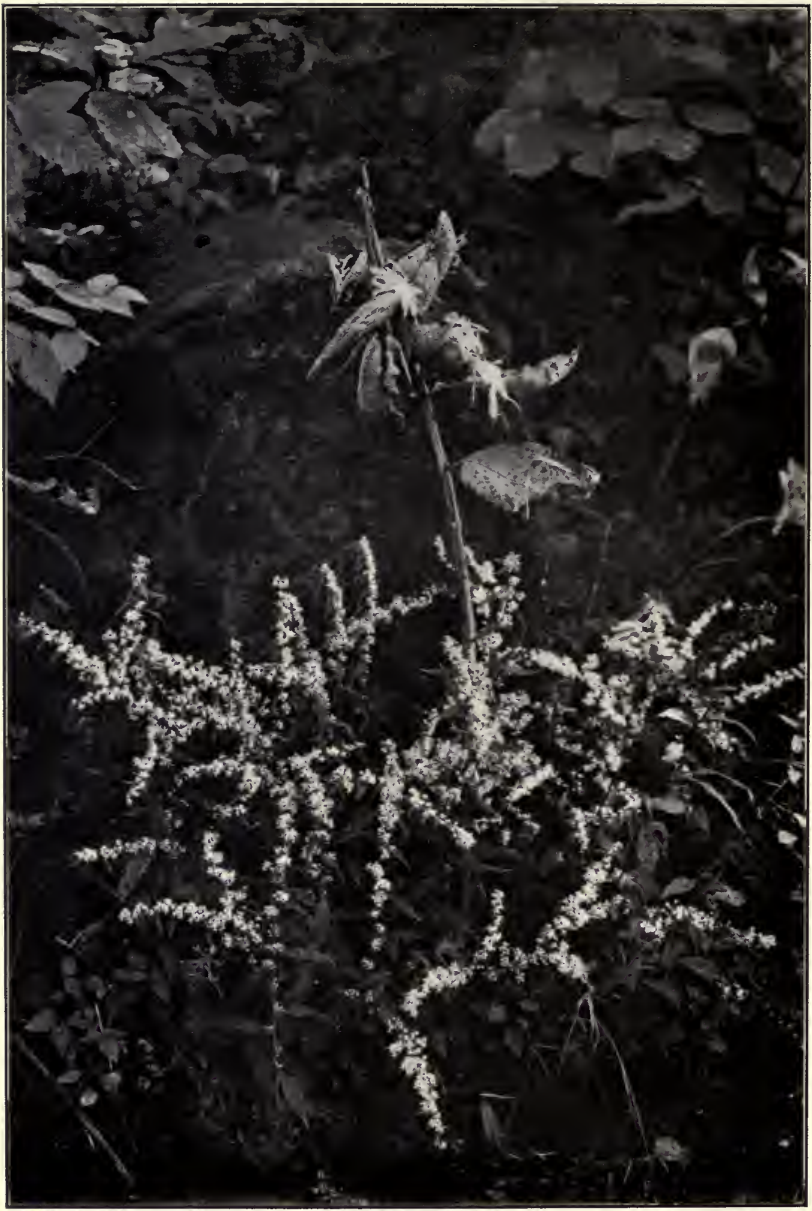

GOLDENROD (Solidago) and MILKWEED (Asclepias). The goldenrods and the milkweeds are among the best known aerial navigators. 


\section{PLANTS THAT BUILD AIRSHIPS 113}

which answers for both sail and rudder; the pine has each of its numerous seeds attached to a delicate parachute, and as the pine cone bursts open, each seedlet flies out into the big world attached to this protecting carrier.

Another group of airship plants, like the clematis, reed mace, and numerous grasses, have feathery appendages.

The most exquisite and dainty balloons are used by the dandelions, milkweeds, common thistle, goldenrods, daisies, and manifold others. In the autumn, when the dandelion's seeds are ready to be sent forth into the world, each baby seed is securely attached to a fairy-like balloon, with delicate, velvety sails, and is so light that it can float for a long distance. The parent plant has also prepared to protect this marvellous structure until ready to send it forth with its precious treasure. In case of rain, before the little seeds are ready to leave the parent, there is a delicate brown shawl or wrapper entirely surrounding the myriads of tiny balloons which fold up, thus protecting the seed-children from the damp.

All the summer Mother Nature is busy preparing her many children who must be sent out into the world alone. Some who are too timid to fly far enough, or who become tired because of weak 


\section{THE HUMAN SIDE OF PLANTS}

wings, soon fall to the ground, where they unfortunately are too crowded to grow, and die from lack of sunshine; others steer their airships out over the big ocean where they swim for a while and finally sink in the water and are eaten by fish; those who have grown too attractive from undue care are soon eaten by birds, who are extremely fond of seedbabies; while many others of these youthful adventurers, who manage to light in apparently suitable places, are eaten by insects; and so only a few are fortunate enough, notwithstanding all the care the parent plants bestowed upon them, to get such a start in life as to become successful and reach their highest point of development.

Those few who are lucky in finding comfortable homes in the autumn, secure from birds and insects, soon fall into a long slumber, while the leaves blow over them, and the snow buries them under, affording a warm, snug bed where they sleep all winter. When the hot sunshine melts the snow in the spring, the tiny seeds burst their brown coats or shawls, in which their fond mothers wrapped them before they ventured out into the world, and each sends down a delicate rootlet to drink in moisture. It also sends up leaves to drink of the glorious air and sunshine. Soon it grows so strong and happy that more leaves are sent up, and finally 


\section{PLANTS THAT BUILD AIRSHIPS 115}

flowers come like those of the parent plant-and the flowers develop into seeds.

The linden provides a kite for its seeds, and hurls them through the air by means of this device, which is so constructed that the wind carries it spirally toward the earth, often landing it a great distance from the mother-tree. Should this kite with its passenger by accident fall into water, it is prepared to float for a long period of time, and if not too far from land it may drift back to shore, like a shipwrecked sailor.

The bladdernut is still more ingenious. It builds an airship with three separate compartments; and in each compartment it places a tiny seed-aviator. Then it sends them forth, secure in the thought that if by chance the airship should fall into water, it will immediately turn into a boat, its bladderlike compartments keeping it from sinking, and all the aeronaut-seedlets will be saved.

The airship plants have learned to adopt all the best contrivances for the safety of their passengers. The wings on the flying seeds have been adapted to service as sails also. See the weary seed-aeronaut sink gently on the surface of the water. He lies there quiet a moment, the tiny feather-sail lightly swaying. A puff of fresh wind ripples the surface. The seed-sailor steadies, the sail fills and 


\section{THE HUMAN SIDE OF PLANTS}

bows, and the airship, now a seaship, glides over the ripples.

Human aeronauts have boasted of -their hydroplanes as the conquerors of air and water simultaneously; but let them observe the tiniest seedling, and they will find their original contrivances but poor imitations in larger form of the hydroplanes in use in the realms of Plantdom for many centuries past.

Man in his frail hydroplane guards against death among the waves by fastening a life-preserver about his body; the aeronautic plants learned to do that many ages ago. These plant life-preservers, also, are frequently made of cork. The seeds of the dock are so safe-guarded.

But the air-tight compartment is the device generally used by the plant-mother to protect her seedchildren from the perils of the deep. The sedges, water-plantain, and many varieties of the common sea-weeds have these compartments.

The airships built by the locust show tiny bulkheads separating the air-tight staterooms in which their passengers are lodged. Should there be some accident on the sea, and part of the podvessel be crushed, or broken open, the untouched compartments will remain afloat and bear at least one or two of the passengers to shore. There the 


\section{PLANTS THAT BUILD AIRSHIPS 117}

survivors will settle, take root and start plant families of their own.

There is a strong humanness about this seed-emigration. It is the eternally repeated story of the mother educating, training, and preparing her children to go out into the world; the setting out, with limitless possibilities ahead; the destruction of some, the degeneration of others; and the success and achievement of those few who reach their goal. 


\section{XIII}

PLANTS THAT BUILD ISLANDS

"Where the grey beach glimmering runs, as a belt of the daron."

$\mathrm{H}^{\mathrm{EW}}$ men realise the tremendous value of plants I in protecting and building up land. Not only do they build islands in the lakes and rivers, and cover them with marvellous flowers and trees, thus making homes for birds, insects, animals, and even for mankind; but by their love of the clean, wholesome sand, they reclaim millions of acres of barren, desolate sand-dunes, not only along the seashore but inland as well.

On the west coast of France is found a good illustration of this sand-reclaiming habit; here for miles and miles the plant-life has reclaimed the barren sand-dunes. Places once as void of trees and grass as the desert of Sahara are now covered with forests of pine, sea-holly, and various kinds of shrubs and sand-loving grasses, all of which aid in binding and tying the drifting sands together. 


\section{PLANTS THAT BUILD ISLANDS 119}

This sand-binding habit of certain plants may be noticed in various parts of the world, especially on islands, and on the sea-coasts of many countries. It is largely due to these plants that many islands exist at all, and that the continents are as large as they are. Sand-binding grasses and other sandloving plants are of sufficient importance to have been made the subject for special consideration by experts in topographical and geological botany, and by land commissioners of such countries as have land bordering on the sea-coast.

An interesting example of the rapidity and extent to which this action of grasses in binding and building lands can attain is shown in one of the reports of the Royal Commission on Coast Erosion.

In Southampton waters were scattered seeds of rice-grass by a ship, whose cargo was chiefly of this grass. Probably but little of the cargo was so lost in the unloading, but this portion, washing up on the shores, grew and spread rapidly, until in its circular progress it had covered the earth to the extent of twenty miles, the distance between Southampton and Hurst Castle.

This sea-rice, or spartina, growing thickly along the mud-banks of the shore, gathered and held much seaweed that was washed upon its stiff points, until 


\section{THE HUMAN SIDE OF PLANTS}

finally the elevation of the banks was raised and their extension into the water materially increased.

The United States Department of Agriculture has done some remarkable work with sand-binding grasses. Large tracts of land on Cape Cod, especially the Province Lands, have been reclaimed from desolation by these sand-loving grasses.

One of the best known is the marram-grass, or sand-reed, botanically known as Ammophila arenaria. It is common along the Great.Lakes, and is found among the sand-dunes of Indiana, along the Atlantic coast, and also in California; in Europe it is commonly found along the coast countries, where it is extensively used to protect the coast against tides and storms. This interesting sandreed has been used as a land-reclaimer in England, Scotland, Denmark, and Holland, for ages.

It does not make good food for grazing animals, because of its dry, hard, wood-like stems; yet, rabbits are fond of burrowing among its roots on the seashore, and they no doubt eat the young shoots. The blades are tremendously strong, and are sometimes used in making ropes.

The roots and the buried stems of this grass grow to an unbelievable length, and gradually become so matted and twisted together as to bind perfectly all land that it invades. In every direction they reach 


\section{PLANTS THAT BUILD ISLANDS 121}

through the damp sands, shoving their way by means of a sharp point at the end of each shoot. At every joint is sent out a new shoot and numerous new roots, in the same way that couch-grass spreads. As the wind blows the sands over a new shoot, the grass keeps climbing above the surface, and so for many feet the sand-hill continues to grow upward. Every drift of new sand is hastily tied, until at last an enormous tract of land is bound and tied, laced and wrapped, until there is no escape from the grass's clinging arms.

Unlike many sand-binding grasses, the marram does not like salt water. It prefers to occupy the sand-dunes that are above the reach of the salt waves; and yet, it will not wander too far inland. This may be due to the crowding influence of ambitious inland grasses.

One of the most striking things relative to the sand-binding habits of the marram is its ability to suck up vast quantities of water. These enthralled patches of earth are always damp, due to the water that has been drawn up by the grass. As a result, all drifting sands immediately adhere to the damp sands, and become saturated in a short time; even the wind is helpless to move the sand grains when once they stick. Dry sands continue to heap upon wet sands; and the ever-eager grass reaches out, 


\section{THE HUMAN SIDE OF PLANTS}

grasps, and securely binds, thus building the vast sand-dunes.

Grasses are by far the most important group of plants; for all grains, such as corn, barley, wheat, oats, rice, and sugar-cane, are only cultivated grasses.

But one of the greatest services that grasses afford mankind is the binding down and retaining of lands. To what extent in this use grasses can be utilised, men have but begun to discover.

To this end, about eighty years ago, the United States Government undertook to reclaim the sanddunes of the Province of Cape Cod; but only since 1895, after these lands had been placed under the control of the Board of Harbor and Land Commissioners of Massachusetts, has the undertaking been conducted in such a manner as to produce good results. In a number of southern and western States, and especially on the Pacific coast, interesting experiments have been made in the same way. Oregon has been using sand-binding grasses not only on the coast, but inland along the railroadtracks as well, where by means of these grasses the barren embankments are protected from wind and rain.

Among the various species of grass used for protecting and building up islands and sandy land, the 


\section{PLANTS THAT BUILD ISLANDS 123}

sea-beach panic-grass is very common. In the marshy salt lands we find salt-reed grass, creeksedge, and numerous other reed-like grasses. The seaside blue-grass is, perhaps, more commonly used than any other kind, especially in the West. This is due to two reasons: because of its sand-binding qualities, and because of its excellence as grazing for cattle. In the South various kinds of sandbinders are used; chief among these are the wellknown St. Augustine grass and seaside oats, which use their sand-collecting propensities to save the water-fronts.

Occasionally an island is formed by a great piece of earth which has broken away from a low-water bank, usually near the mouth of a large river, and floated out to sea, the soil being held firmly together by matted grass roots. The sizes of these floating islands vary from a few feet in diameter to an area of several acres. Sometimes they carry only tiny crawling insects or no life at all; at other times there are trees and many small animals. Few of the islands exist long after they float out on to the rough waters of the ocean; but one or two have been known to travel many miles, resisting for months and even years all efforts of the waves to buffet them to pieces.

Some islands rise out of the ocean, perhaps be- 


\section{THE HUMAN SIDE OF PLANTS}

cause of a volcanic upheaval, and such islands are usually stationary; but here, too, plants play their important part. A big rock rises out of the sea, drifting seaweed begins to lodge on it, sand and seashells soon are heaped upon it, all increasing the height of the island; more plants, especially grass seeds, drift to it; finally birds come and bring more seeds; perhaps cocoanuts think it a good resting-place from their long sea voyages, and stop; the seeds of the binding-grasses start their work of binding the soil together; later even pine-trees spring up; and lo! a habitable island is the result.

This ingenious binding and tying of the driftsands by plants is done largely by means of their roots. And there are, in addition to the grasses, many small shrubs and trees which are engaged in this work.

On the western coast of the United States there is a yellow lupin with exquisite pale-green leaves, and yellow blossoms which sleep at night. This lupin is usually one of the first settlers on a new island. Its long, fibrous, rope-like roots bind the drifting sands together, like so many long fingers; other seeds, drifting by, find a comfortable place to germinate and grow. And soon the island becomes a substantial body of land because of the patient work of these plants. 


\section{PLANTS THAT BUILD ISLANDS 125'}

It is interesting to know that many small grasses which appear to be only two or three feet high are in reality often forty to fifty feet from their lowest roots to the tip of their blades above the earth. As each stalk of grass sends out numerous others, each of which is covered with myriads of small thread-like roots, it is not difficult to understand how tightly bound the drift-sands become. These living threads have sewed them together. The sands blow over the grass, of course; but immediately it begins to send out roots and to send up stems.

There are several species of the mangrove-tree (Rhizophora) that have a unique way of building islands. The appearance of the mangrove is such that many strange superstitions have arisen regarding it. By some of the natives on the coast of Africa it is supposed to walk around in the water at night; others regard it as the mother of the earth, because it reclaims land from the sea. The fantastic shape of this tree, because of its method of branching, is very unusual. There are several species; two of them, common to Asia, Africa, and Australia, allow their seeds actually to germinate before leaving the parent tree. The fruit, when mature, resembles a large inverted berry containing one seed; this fruit is well protected by seed-leaves, 


\section{THE HUMAN SIDE OF PLANTS}

and is usually about one and one-half feet in length. From the lower end of this fruit grows a long root, sometimes attaining the length of two feet before the fruit is dropped from the tree. When the root-end of the fruit sticks in the mud, the lower part, or root-tip, is ready to begin feeding the upper leaves which are about to sprout in the new plant. Thus another young tree is started. Had the fruit not germinated before leaving the parent tree, in all probability it would have rotted in the mud and water before it had a chance to germinate. How wisely the mother-plant acted before sending her child into the world to struggle for itself!

But even that protection is not sufficient on wind-swept islands; and so, the mangrove-tree produces aerial roots, which it sends forth from the many-branching stems. It is by means of these manifold roots, or walking-feet, that the mangrove is enabled to reclaim land from water. It has proved itself to be an ingenious island-builder; and not only islands, but inland swamps are filled with these strange water-walking plants.

In several parts of the United States, especially in Texas, Louisiana, and Florida, the mangrove grows in abundance; but nature does no unnecessary work, and as most of these trees grow under 


\section{PLANTS THAT BUILD ISLANDS 127}

more favourable conditions than those that produce islands, it is not necesary for them to have so many aerial roots, nor to spread their branches so profusely; so they stand erect, and reach a considerable height. These trees are covered with myriads of leaves which fall annually and thus build up the land.

Most plants which build islands-such as the searocket, the horned-poppy, and the sea-holly-not only love the salt water, but actually like the rough life; many preceding generations have inured them to such conditions, until now they could not thrive without them. 


\section{XIV}

PLANTS THAT PRODUCE LIGHTS; PLANTS THAT SEE

'Tis said at Summer's evening hour,

Flashes the golden-coloured flower,

A fair electric flame.

-Coleridge.

QHOULD one walk through a dark forest at $D$ night, especially in the tropics, one would frequently see strange lights among the foliage and decaying leaves. These lights are really luminous leaves, and may be of the elm, oak, cottonwood, or beech. If closely examined such leaves prove to be damp, and most of them are yellow and covered with spots. The cause of the leaf's luminosity is not due to the substance of the leaf itself, but to a fungous growth on the leaf.

There are numerous light-producing fungi and algæ; the light-developing qualities of these plants being dependent upon the amount of oxygen they contain. There are also luminous mushrooms. Perhaps this production of light may be their method of attracting the beetles, moths, and gnats 


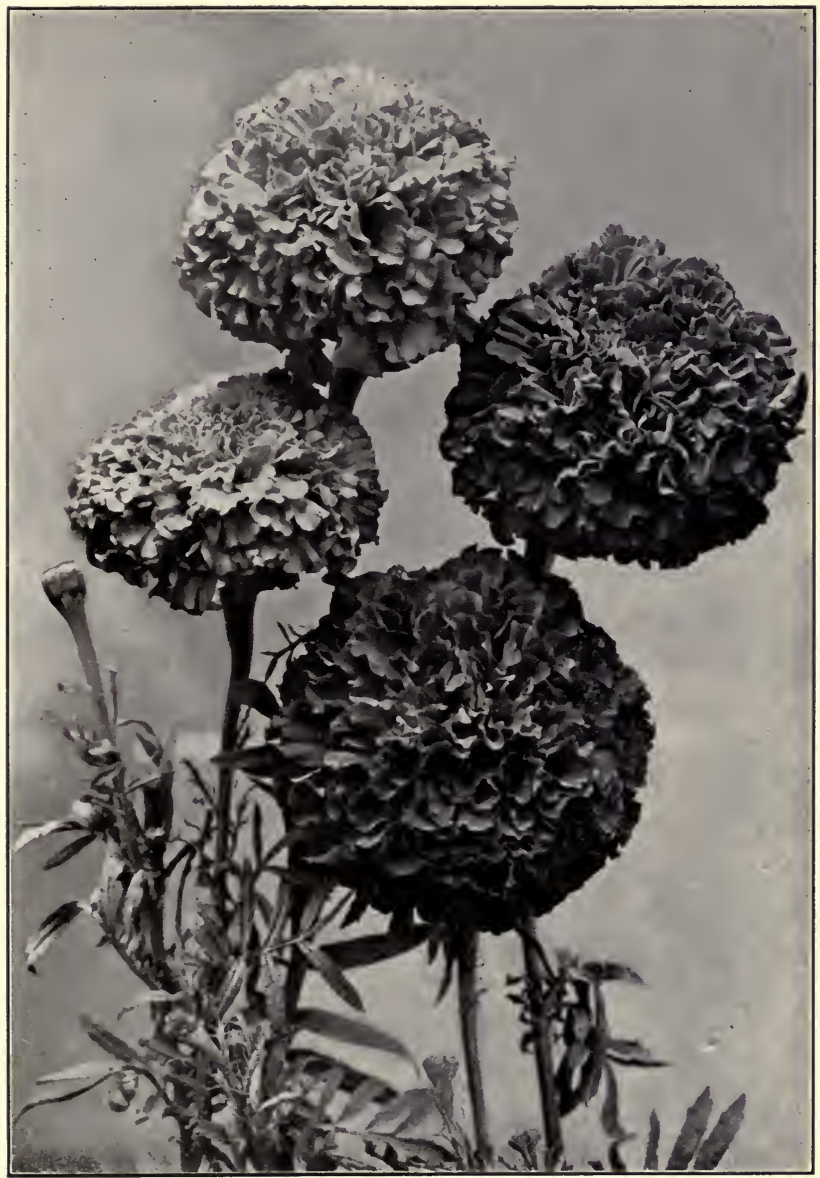

\section{MARIGOLD. Tagetes erecta.}

At night this plant illuminates its blossoms by emitting waves of light that play over the petals like mimic lightning. 


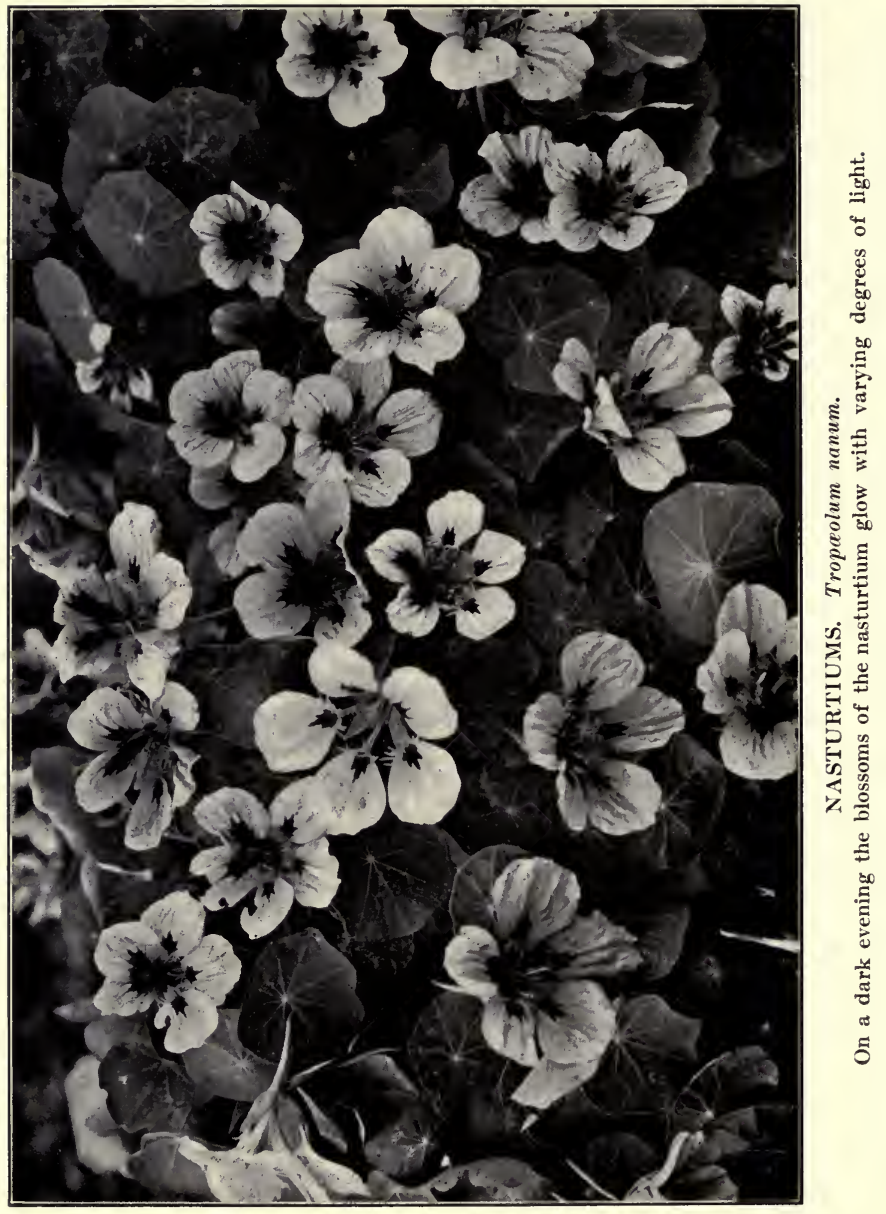




\section{PLANTS THAT PRODUCE LIGHTS 129}

-which lay eggs in the spore-bearing tissues of these plants. Thus the plant lights up its house for its guests, just as men light their houses at night.

The light produced by fungi is due to phosphorescence. It is commonly found in old wells, caves, and especially in mines. Here it produces a most weird effect on the observer. The light is steady, and constant, never flashy, or glimmering, and is usually of a white, green, or blue character. The effect produced is not unlike that of moonshine lighting up a fairy castle! And so bright is this light that one may easily distinguish objects near at hand.

Numbers of the larger flowers, like the sunflower, nasturtium, marigold, and tiger lily, emanate a phosphorescent glow. The lights given forth by these plants are more varied in colour than those in the deep caves and mines: some are violet, others green, and still others orange or red.

Many interesting superstitions have arisen regarding the double marigold, whose deep orangecoloured flowers give forth on dry, clear evenings coruscations of mimic-lightning which plays over the petals.

"Flowerlight" may easily be seen by any one who will but have the patience to wait and watch 


\section{THE HUMAN SIDE OF PLANTS}

for it. However, all do not see it equally well, and for this reason many claim that to see it one must be possessed of abnormal sight.

But these strange ideas regarding the so-called "corpse-lights" and "will-of-the-wisps" are being fast exploded by science. Plants have a way of bottling up sunlight, and giving it forth when they desire; this phenomenon is well understood. The pokeweed gives forth a dark greenish lustre in the dark; and the scarlet poppy emits tiny waves of reddish light after sundown.

The dainty snowdrop emanates light to a pronounced degree. Its drooping white blossoms appear almost as so many dim electric bulbs.

On the western plains of Texas there grows an orange-yellow flower in great abundance, which is known as the Alamo-weed. This plant gives forth a very strong light, a steady glow, which is evident at a distance during the hours of darkness. To most residents of the temperate and torrid zones, the tiny "lightning bug" is a familiar sight on summer evenings; and on the Texas plains, where the Alamo-weed finds its home, there are great quantities of these phosphorescent insects. During the daylight hours the flowers of the Alamo-weed, a phosphorescent plant, are thickly covered with apparently slumbering phosphores- 


\section{PLANTS THAT PRODUCE LIGHTS 131}

cent lightning bugs! Whether there is some relation of source and supply here-either the plant giving of its phosphorescence to the insect, or vice versa-or whether there is merely an attraction of likes; or whether there is indeed any connection between the kindred powers of insect and plant, and this intimate association, is a question that yet remains to be answered.

When the Creator made light, that was not enough; there must be eyes to appreciate this light; so He created animals with eyes, and human beings with eyes, and lastly, although the average person knows it not, plants with eyes, that they too might worship this great work of their Maker.

The number of plant eyes is legion. They are usually tiny cells located in the epidermis of the leaves, and occasionally on the leaf-stalk. Numerous experiments have been made by Dr. Haberlandt which prove conclusively that the eyes of many species of plants are capable of detecting as slight shades of variation in light as are those of man. This is amply proved by the fact that certain plants, like the vetch, pea, or lentil, may be so influenced in their earliest stages of growth that they deliberately turn toward lights.

The scientific world now thoroughly recognises that plants have eyes, and actually see! Not only 


\section{THE HUMAN SIDE OF PLANTS}

do they respond to light, but they give every other evidence of the use of their eyes in their work.

The eyes of plants are of two distinct kinds; one kind, the less complex, are made by smooth epidermis, and the cells have a plain outer covering. These are very similar to a glass window which allows the sun's rays to pass through, and fall on the objects within a room, but in no way aids in concentrating the rays of light in definite places. The other kind of eyes are formed of papillose epidermis, whose outer and inner surfaces are so made as to produce plano-convex lenses. These readily concentrate the rays of light over a definite area, and in this respect are very similar to human eyes.

In the study of light-producing plant types, as in the understanding of all types and classes of plants, the average botanist has but knocked at the outer door; while before him is a labyrinth of many doors and many barriers. Apparently the secret passage to the centre of this maze, to the heart of the flowers, lies in the / attuning of the human nature to the nature of the plants. Science tells us much, but without an absolute communion, a thorough accord and responsive affinity between human soul and plant soul there never can be a thorough understanding of the nature of the plants. 


\section{XV}

PLANTS THAT CARRY LIFE INSURANCE

$\mathrm{N}$ the plant kingdom, as in the human, the idea 1 of preparing for a rainy day, and also of providing for the protection of offspring, has led to the plants' highest and noblest development. Men carry life-insurance policies so that in case of death their families will be protected, and their children be given a fair chance for success in life. Life insurance with them, however, is of comparatively recent origin; but with the vegetable kingdom it is not so: for countless centuries the plants have been familiar with all forms of insurance. It is by means of their wonderful experiences, through this long period of ups and downs, failures and successes-just as in the life of human kind-that they have gained their remarkable social and political, as well as religious and spiritual understanding-underneath all of which there must be a divine wisdom!

Every plant at its death leaves a legacy to its offspring. This legacy is usually in the form of 


\section{THE HUMAN SIDE OF PLANTS}

nutriment in the seed or bulb. Some of these legacies are small, others are large; in other words some plants, just as men, carry a small life insurance, others carry a large one. Most nuts, acorns, beans, peas, and especially large fruits, like the cocoanut, are exceedingly rich in food material, and may be said to have received a large legacy from the parent plant. On the other hand, such plants as the mustards, violets, broom-rapes, poppies, verbenas, phlox, orchids, and ladies'-tresses, are left with such a small quantity of nutriment that their babies must go to work early and develop chlorophyll in order to produce food and clothing for themselves. Like the child of the poor compared to the child of the rich: one must work for every penny it gets, the other has all its wants supplied.

Man has various kinds of insurance policieslife, accident, health, and even those against old age and decreptitude; the same is true of many plants.

One of their best known methods of insurance is by storing away food-material in the basement, or underground bank; that is, in bulbs and roots. These bulbs are not really all roots, but some parts of them are buds from which new plants will spring when given a suitable opportunity. Among bulbous plants are tulips, lilies, dahlias, and many com- 


\section{PLANTS CARRY LIFE INSURANCE 135}

mon vegetables, such as Irish potatoes. These potatoes, if cut into pieces, without having their "eyes" damaged, and placed in the right kind of soil and climate, will soon develop into new potato plants. Not many bulbous plants have "eyes": that is, the places from which the new plants spring, as in the potato; but those that do not usually develop separate bulbils. That part of the potato other than the eyes is the food insurance that the parent potato has stored up to feed the new plants until they are able to get nourishment from the soil.

Some plants protect their food insurance by burying their stems underground; the stems thus buried are known as rhizomes. Solomon's seal, sedges, iris-all these bury their stems under the soil; but other plants, many of which grow in the tropics, like tree-ferns, owing to the mild climate do not need to conceal themselves from the inclement weather by burrowing underground.

In bulbs and rootstalks which are protected underground, not only a sufficient quantity of foodmaterial is saved to feed the plant, but often enough is contained to form new bulbils. Especially is this true of lilies, tulips, dahlias, crocuses, and hyacinths.

The century-plant of the western plains stores up food for a number of years, preparatory to blos- 


\section{THE HUMAN SIDE OF PLANTS}

soming. It is because of this long period of "annual payments," that many people erroneously believe the Agave, as it is botanically known, blossoms only once in a century. The blossoms, which really appear usually about once in fifteen years, develop very rapidly, and thus require a large quantity of ready prepared food-material. As the living plant benefits by this foresight, its insurance might be classed under the head of an "endowment policy."

Among the striking illustrations of plants that have developed life insurance to an art none are more worthy of mention than the cacti. These giant inhabitants of the desert regions have long ago learned the value not only of saving for the rainy day, but of saving on the rainy day: their "hay day" is when it rains! It is at this rare time that they are enabled to drink up a sufficient quantity of water to fill their internal sponges, or small cisterns, and thus insure themselves against the long-continued drought to follow.

These cacti have become very strong and courageous, for they have fought and won many battles. Their spines defend them from grazing animals, and their bodies have become so shaped as to protect them from too much sunshine, which might cause their carefully stored water to evaporate; thus 


\section{PLANTS CARRY LIFE INSURANCE 137}

they are well prepared to exist where weaker plants would soon perish. Some cacti are small and creep along the ground; others are giants that grow to a height of ninety feet in their native soils. The largest of the entire family is known as Cereus giganteus, a native of Mexico. Small specimens of it may be seen in hot-houses, but it can be seen to advantage only on the deserts of Mexico or Arizona.

The sea-urchin cacti are noted for their fantastical shapes, and exquisitely coloured flowers. Second only to the orchids for beauty and form are they to be numbered. If it were not for their spiny daggers, their flowers would stand little chance of being undisturbed.

The old-man cactus is a species which makes a striking appearance in a flower garden. It is covered with long, silken, white hair, resembling the white locks of an old man. It is easily grown from the smallest cutting, or from seeds.

Perhaps the best known of all these desert plants is the Cereus grandiflorus, commonly known as the night-blooming cereus, or "Queen of the night." It yields very readily to cultivation; and owing to its exquisite white flowers and its delightful perfume it is always a welcome guest where grown. It blossoms only at night, and each blossom lasts 


\section{THE HUMAN SIDE OF PLANTS}

but a few hours; one plant, however, may have a good many blossoms.

Another interesting case of insurance may be found in the formation of leaf-buds, from which new leaves are developed. These leaf-buds were carefully prepared long before the preceding summer's leaves had fallen; and in no way could the plant better show its remarkable forethought.

In bulbous plants, such as daffodils, snowdrops, hyacinths, and lilies, a big supply of food-material is stored away for future use. This supply has been savyed from the past season's earnings-another "endowment" scheme.

All who have raised hyacinths in a bowl of water near a sunny window realise that all the plant requires to develop green leaves and marvellous flowers, laden with perfume, is plenty of water and light. What a wonderful transformation takes place! This is entirely due to the energy of the sun converting the stored material of the bulb into this fantastical and glorious blossom.

Horticulturists and gardeners have learned how to cause bulbs of lilies, dahlias, and hyacinths to store up an abundance of food-material, by cutting down the plant each year just before its flower-buds appear. This enables the plant to store up several years' savings, and as a result when it 


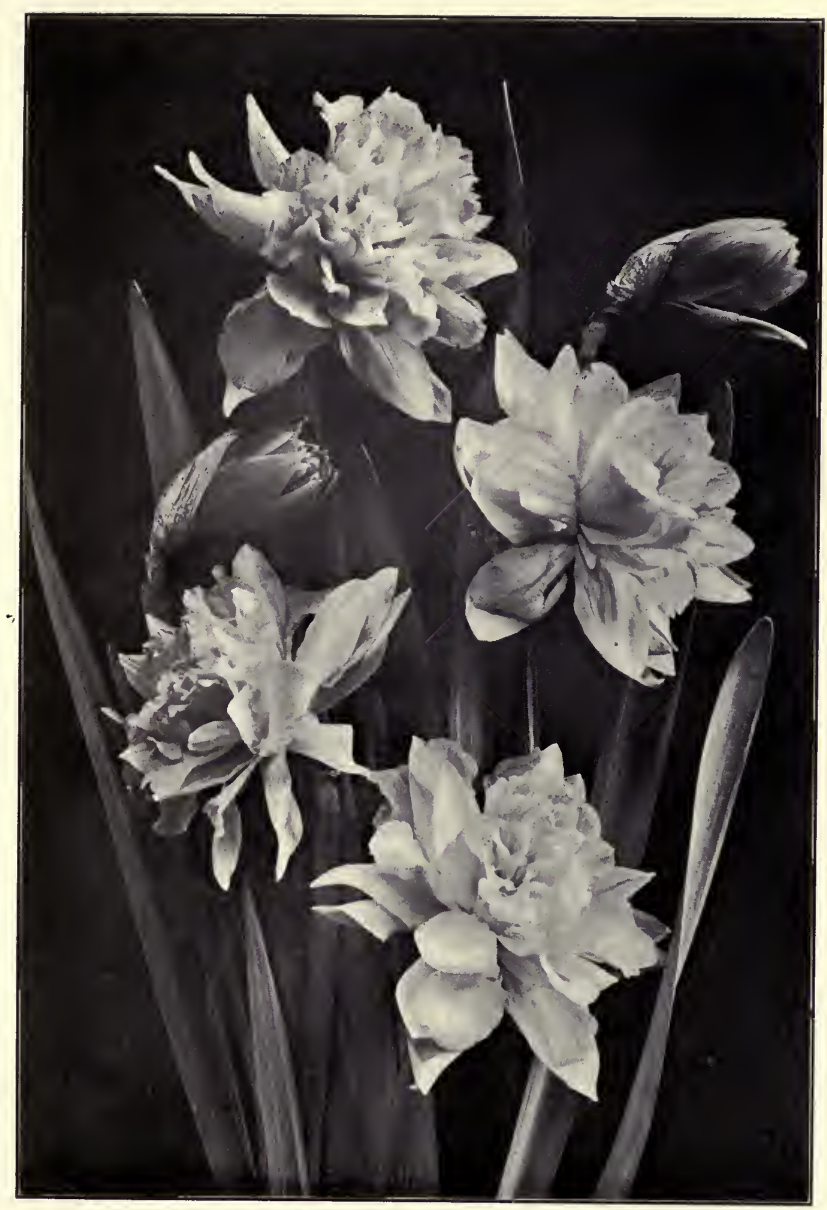

DAFFODILS. Narcissus telamònius plènus.

Typical of the bulbous plants, the daffodils store away a big supply of food material for future use, 


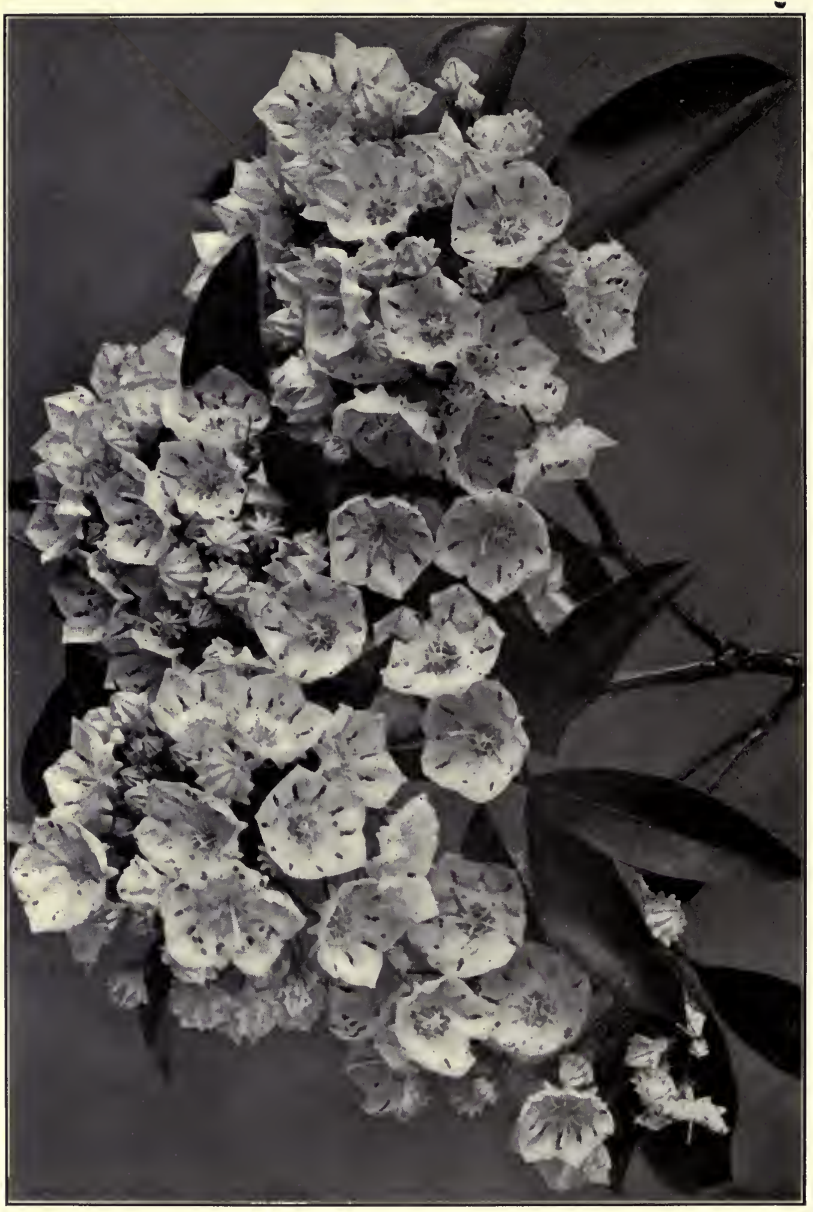



: خ

$\therefore$

픈

-

․․ㄹ

숑

:

돌 욜

苛

几

$7 \pm \frac{10}{4}$

亟

- 50

근

ํํำ

Ð

을

a

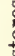

$\frac{8}{6}$

范

궁

윽

है 


\section{PLANTS CARRY LIFE INSURANCE 139}

is allowed to blossom, a gorgeous display of flowers is the reward.

During the winter season most plants have their vacations; this period is spent in sleeping and resting. But even while they are resting, plants are not idle, for a great preparation for their early awakening is going on. The skunk-cabbagè can hardly wait until February to peep up. And away under the snow and ice the trailing arbutus has already put forth its delicate, pink buds, ready at the first invitation of the early spring sunshine to burst into bloom. The glaucous willow, also, is ready to reward with nectar the first bee that ventures forth in the early, chill winds; and even the wake-robin (Trillium erectum), with its disagreeable odour, is prepared to feast the first flies of the season; all as a result of the foresight of the parent plant in preparing for their early appearance-in other words, in providing insurance.

Many plants use colour and beauty to insure their children a proper location in life, for when these children once choose their homes and become established, they rarely change. The bright, red colour of the apple attracts birds, animals, and human beings to it, in the same way that the beautiful red rose attracts insects by its colour and fragrance; the apple, too, has a wonderful perfume, as do 


\section{THE HUMAN SIDE OF PLAN'T}

most other fruits, to say nothing of their flavours and sweet juices. These qualities make the fruit an object of much attraction, and cause it to be sought after; while the seeds, transported with the fruit, are protected from harm by hard or bitter coverings. This method of insurance is used by various kinds of berries also, and by haws, grapes, and figs.

One of the most ingenious ways of insuring the welfare of the offspring is used by certain small plants, which actually place them under the ground, or hurl them away to places of safety.

"With fierce distracted eye Impatiens stands, Swells her pale cheeks, and brandishes her hands, With rage and hate the astonish'd grove alarms, And hurls her infants from her frantic arms."

Not only the forget-me-not, but many other plants have this interesting method of insuring a proper dispersal of their fruit. The squirting cucumber will burst open with the slightest touch and spit its seeds out with a bang, like a squirt-gun.

The common peanut, or groundnut, carefully buries underground its fruit pods, or nuts. These peanuts are produced from simple underground flowers, and the parent plant has buried them that they may escape the attention of enemies. The 


\section{PLAN'TS CARRY LIFE INSURANCE 141}

plant actually buries its children, before they are born!

A most interesting method of insurance is used by pussy willows. In the very early spring, the baby catkins are covered with downy hairs, which keep them warm, and later the seeds are snugly wrapped in small pods. The willow takes no risks, and its children stand a good chance of success in life.

The buttonwood, unlike many trees and small plants which send their seed-babies into the world in the autumn, keeps its children at home, attached to the parent tree by means of slender ropes or cords. These seed-children are covered with soft, brown hairs, and are massed together in round balls; and all through the long winter they swing to and fro in the wind, rocking like babies in a cradle, perfectly protected from the cold. When spring comes, the big seed-pods open, and away go the hundreds of seeds, all seeking a pleasant place to live.

Plants are frequently self-sacrificing. The mother plant is just as much concerned about the welfare of her offspring as are human mothers. Each little seed goes forth into the big world carefully prepared to begin the struggle of life for itself. 


\section{THE HUMAN SIDE OF PLANTS}

Of course some plant-children are better insured than others; just as some human parents leave more insurance to their children than do others. The plant gives each seed a legacy of food-material, which is sufficient for it to begin its individual life, with only the aid of water and sunshine. And in what way is the close relationship between plants and animals, and even human beings, more clearly shown than in this wise provision of life insurance, which is characteristic of all? 


\section{XVI}

PLANTS THAT KIDNAP

D LANTS actually kidnap! Some are worse than highway robbers, allowing their captives to die in confinement or killing them outright; others are merely selfish and desirous of enslaving or using their prey to their advantage without giving value received. It is one of the strange inconsistencies of nature-this capturing and holding of an insect by a plant which makes a victim of the friend that has benefited it. As most of the kidnapping plants receive no sustenance from the death of their victims, it is more kind to suppose that this act on their part is unavoidable.

The great family of Orchids claim the first mention as kidnappers. Their purpose is fertilisation, and their methods are many, and cunningly devised; although they are not cruel, for they release the guest as soon as the act of fertilisation is accomplished. This kidnapping may be excused when it is considered that without the aid of certain insect "go-betweens" many species of orchids would 


\section{THE HUMAN SIDE OF PLAN'TS}

soon become extinct. There are, however, a few species, like the bee-orchid, which are self-fertilised and do not need to employ such cunning.

The cuckoo-pint is extremely discourteous to her guests! After they have been bidden to enter, and are once inside, they go to the dining-room, or lower chamber, where the sweets are stored; quickly the flower closes, and the imprisoned insect is not permitted to leave until the pollen from the male flowers is properly distributed to the female flowers. In this plant the male and the female flowers live on the same stalk. But the fertilisation cannot take place without the aid of a pollen-bearer, and the poor trapped insect acts as the needed messenger. When the fertilisation has been accomplished, the flower slowly opens, and the affronted insect departs.

Not the least curious among the kidnappers, and surely the most cruel, is the goose-plant. This strange plant monstrosity is botanically known as Aristolochia gigas, and its native home is Guatemala. The flower-bud is shaped strikingly like a goose swimming in water. This bud is usually about fourteen to sixteen inches in length, and when it first bursts into bloom, the curve, representing the breast of the goose, displays the most exquisite velvety linings of dark purples that shade into 
wine colour. The full blossom is not unlike a kite in shape, with a tail about eighteen inches long.

The most frequent victims of the goose-plant's diabolical lures are flies and crawling insects. They are attracted by the seductive odour which lures them into the long throat, from which they never escape. There is a deep, slippery lining in the throat, and the way in is very easy; but, owing to a steeply inclined phalanx, there is no way out; and the deceived insect, after having distributed the pollen from the male to the female flower, must die a hopeless prisoner.

A cousin to the goose-plant, and one equally famed for its kidnapping proclivities, is the Aristolochia clematitis. Its deceived prisoners are held sometimes for a period of two days; but when their work is done they are set free. The insect enters through a narrow tube which is lined with tiny daggers pointing downward. When he has drunk his fill and would depart, he finds the passageway closed by the impassable row of sharp points. In captivity he must remain until the flower is ready for his services. Finally the barrier dries up and, shrinking, gives the deluded wanderer a chance to escape.

Another Aristolochia (A. macrophylla), commonly known as the pipe vine or Dutchman's pipe, 


\section{THE HUMAN SIDE OF PLAN'TS}

because of the resemblance of the long, tubular flowers to the bowl of a pipe, employs the same means for kidnapping as does its cousin, the clematitis. The bee enters the narrow opening to the flower, finds no obstruction to prevent his pushing his way along the inward bending hairs, reaches and sips of the nectar, turns - and faces a phalanx of dagger-like points! While the flower holds him prisoner, he is not starved, for there is an abundance of nectar to last him the two or three days that he must remain until the tiny ovules have been fertilised, the pollen has ripened, and he has been well powdered with the golden dust that he is to carry to the next flower on his rounds. Then, and then only, the dagger-hairs wither and the bee is permitted to buzz his angry way out.

The Milkweed family, which uses insects as its means of fertilisation, has an interesting method of catching and holding its guests. In certain species, like the wavy-leafed milkweed, this is done by means of adhesive glands.

The moths and other insects which visit the Physianthus albens, a vine-like plant of New Zealand, are deliberately gripped by its deadly anthers which it uses as jaws; and they are held fast until they have given their utmost aid toward the fertilisation of the flowers. 
Jack-in-the-Pulpit appears pious enough as he stands in his royal ministerial chamber surrounded by draperies fit for a king! But beware of him, for he is a hypocrite! Like the wolf in sheep's clothing, he depends upon his ministerial robes and his respectable relatives-for he is a cousin to the stately calla lily - to disguise the innate deceptiveness of his nature. His sanctimonious smile and his dignified appearance are only lures to the unwary. If he preaches to any flock, it is to the dead and decaying insects which he has beguiled into his death-trap.

Inside the palatial walls of Jack's pulpit there is a slippery, treacherous lining. When gnats and other small insects enter with the hope of finding shelter and food, they slide easily to the bottom, whence escape is impossible. Here at the bottom of the pulpit may be found the corpses of many wanderers-all kidnapped by Rev. Jack!

Larger insects frequently escape from this lure and thus carry the pollen to other plants, but no such hope can be offered to the smaller ones. Like the weaker human beings, they must finally succumb to their fate.

The fire-pink, or Virginia catchfly, has been well named. Its wonderful scarlet blossoms seem to fascinate insects by their fire-like brilliancy. This 


\section{THE HUMAN SIDE OF PLANTS}

open woodland flower also is a kidnapper; although it is not one of the worst kind. As it must protect its flowers from pilfering insects that crawl, the flower-stems are covered with a sticky fluid, and those ants which persist in trying to ascend the stalk are held fast by the glue until they are dead. A case of slaughter, but in self-defence.

Another member of the Pink family, and one equally skilled in catching insects, is the starry campion. In the tubes of its snowy white flowers are tiny drops of honey that must be saved to reward the flying insects which carry its pollen. Therefore, it spreads a sticky fluid on its calyces, and occasionally on its pedicels, to catch crawling intruders; and in this way it entraps the would-be burglar.

As there are no general prisons in the plant world, each individual plant is compelled to hold and imprison its own enemies. Thus kidnapping is really forced upon them.

The common or card teazel, sometimes known as gypsy combs, has learned through ages of experience how best to care for itself. Not only does it defend itself against browsing animals by means of its numerous prickles; but, that it may be sure of enough food, it has learned to kidnap insects. This is done in a most novel manner. The 


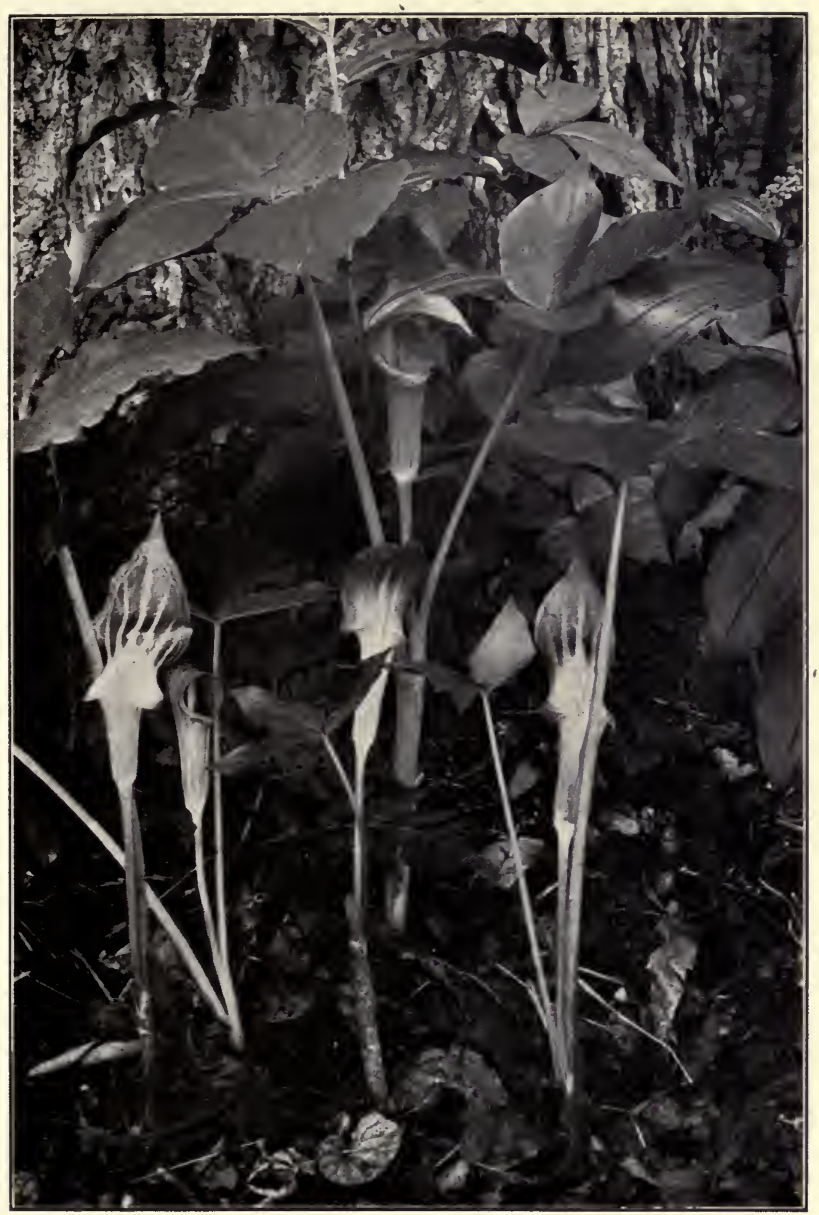

JACK-IN-THE-PULPIT. Arisama triphyllum.

This flower, loved of all childhood, is a shameless kidnapper. 


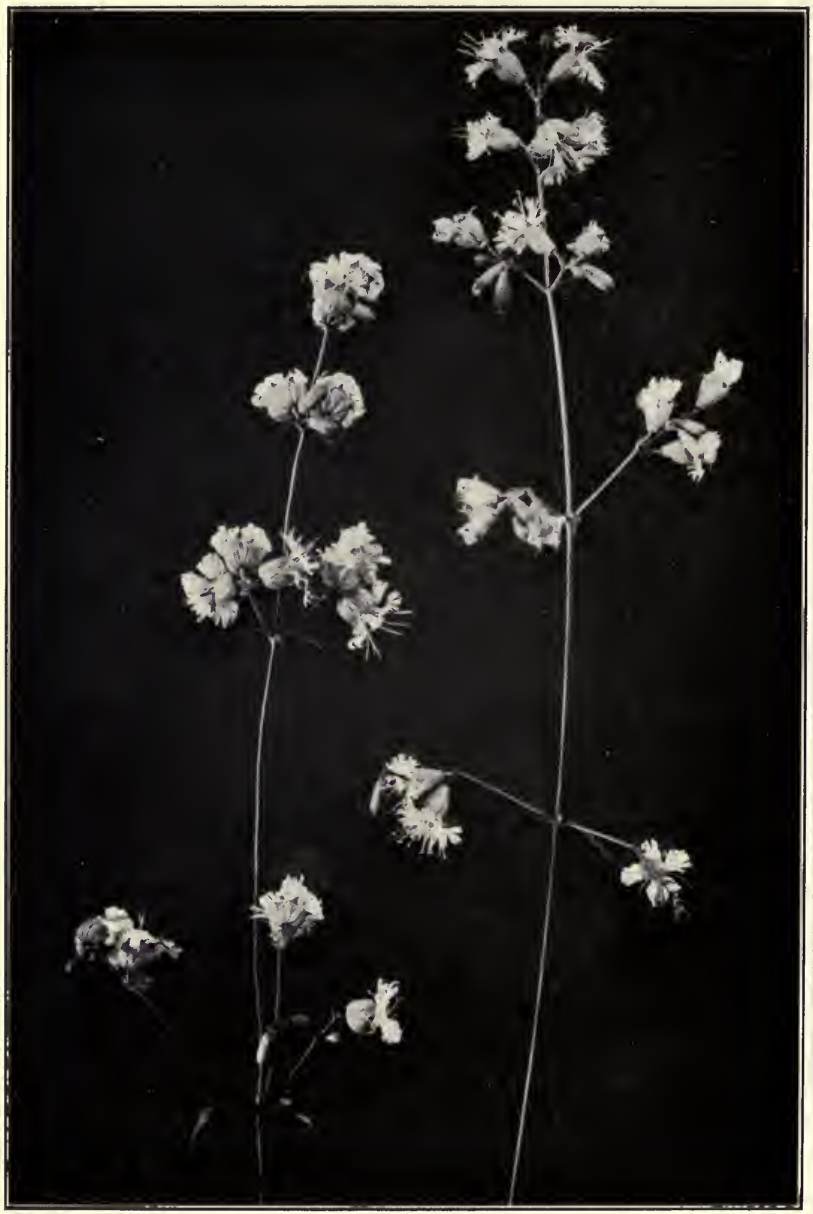

STARRY CAMPION. Silene stellata.

One of the many kidnapping plants which catch insects by means of a sticky fluid with which they cover their stalks. 
lower part of the upper leaves form themselves together so as to make a small cistern. Fluid, supposedly water or dew, gathers in the cistern, and here numerous tiny insects find a watery grave. The poor creatures walk in, are unable to escape, and so, after vain attempts to get out, fall exhausted into the fatal tank.

The teazel is not dependent upon insects for its food; but it is becoming more and more an insecteater. No doubt, in the distant future it will depend entirely on a carnivorous diet. At present it does not digest its prey, but only absorbs, in the form of liquid, the products of the decayed bodies of its kidnapped victims.

Not the least among the kidnappers are the Rhododendrons. Who would ever suspect them of such deeds? Yet it is true; and their wonderful clusters of rosy pink blossoms are carefully protected from crawling insects by the plant's skillful method of spreading glue near the base of the flowers. This glue catches and holds all creeping intruders. But the Rhododendrons kidnap only in self-defence and must not, therefore, be placed among the criminal plants. The mountains in parts of Pennsylvania, especially in the Alleghanies, are literally covered with Rhododendrons. Few flowers are more beautiful. One is silenced in their presence 


\section{THE HUMAN SIDE OF PLANTS}

by their rich, massive beauty. Surely their insectcatching is justified; for they are fertilised only by flying insects, and they must protect the honey which is to pay the bees and the butterflies for their labour.

Indeed, there is generally a cause which should at least partially excuse the questionable actions of plants. With most kidnapping plants the act is one of self-defence; and surely self-preservation is the first right of every living thing! True, Venus's fly-trap, the sundews, and others, do lure their prey that the insects may be killed and eaten by the voracious plants; but in spite of these far from admirable habits there are many beautiful characteristics which are always evident in plants that kidnap. 


\section{XVII}

\section{PLANTS THAT ENTERTAIN}

But 'tis the greater art, to entertain!

-Raymond Comstock.

CIVILISED flowers make good hostesses.

Not only do they decorate their houses in gorgeous colours, perfume the palatial inner walls, and powder their pretty faces with golden pollen, but, also, accepting as a proverb the couplet,

"No man hath entertained his best, Till bread be broken with his guest,"

they actually prepare inviting feasts for their insect guests. These feasts are, however, really in the nature of fees, and are given to the guest to pay him for carrying pollen to another plant.

One thing the plant must be most careful to avoid: that is, not to feed the guest too much, nor even to satisfy his appetite, as he might then not call upon another flower.

All flowers are not considerate of their guests. Some hostesses have the discourtesy actually to 


\section{THE HUMAN SIDE OF PLANTS}

break their petals when a bee or a butterfly alights upon them. This lack of hospitality is accorded by the hemlock stork's-bill.

Perhaps of all plant-hostesses the yucca stands first. The yucca is not unselfish in her elegant manner of entertaining; neither is she unwise. She is well repaid for all her trouble in entertaining her guests-she has but one kind, the yucca-moth.

The yucca and her guest are inseparable: where one is found, there also is the other. Examine the yucca blossom and you will always find in it the delicate, fairy-like guest, draped in her strangely beautiful white costume. If it is daytime, the guest will be resting with folded wings, waiting for the busy night hours; for then she has work to perform.

The male yucca-moths are seen more often than the females. They flit from flower to flower in the evening, gathering pollen and looking after outside affairs in general, while their mates are busily engaged in the flowers. The female moth has no time for visiting among her neighbours, for she mustconstantly attend to her household duties. She must prove a satisfactory guest, reciprocating the generosity of the plant, which produces food for her offspring. This the moth does by gathering together large balls of pollen, packing and rolling it 
with great care. In and out among the flower she crawls and flits, scraping a bit of pollen from this anther and a bit from that. Finally, when enough pollen has been gathered to form a ball twice the size of her head, she carries it to another flower. In the pistil of the new flower she darts her ovipositor, making a tiny nest in the soft tissue, where she imbeds her first egg. Her next move is to mount to the top of the style and place the ball of pollen on the stigma, forcing it down into the tube, that it may serve as a cover and protector for her egg. Incidentally, both egg and pollen reach the ovary of the flower, thus fertilising it. Sometimes the moth deposits more than one egg in a pistil, but each egg is placed in a different part, and a fresh act of pollination follows; as if she were making payment in advance for the care which the yucca is to give to each of her babies.

This is a case of exchange- one of the multitude of instances that are found occurring between members of the plant and the insect kingdoms. The yucca nourishes and cares for the family that it entertains: the moth fertilises its generous hostess.

When the moth's egg finally hatches, the larva finds itself in a very "garden of paradise." Here it feasts on the delicate tissue of the plant until the plant's own seeds are ripe, when the larva bores 


\section{THE HUMAN SIDE OF PLANTS}

its way out and crawls to the earth, living there in the form of a chrysalis until its resurrection as a full-fledged yucca-moth.

Most plants are honest. Even the kidnappers offer some reward, at least a temporary one, to the insects they deceive; but there are a few plants with showy blossoms, like the Grass of Parnassus, which employ the services of insects without giving any remuneration. In their flaring costumes and their unlovely habits they are remarkably analogous to the flashily clothed "confidence man" whom the human race endures.

These plants are deceptive. In the centre of each of their blossoms they create the peculiar illusion of a drop of honey-the plant's "gold brick." This is done by means of tiny hairs skillfully arranged around a shiny knob, appearing for all the world like an honest drop of pure honey. Numerous insects, seeing what they believe to be glistening nectar, visit the hypocrites in the belief that they will receive a delicious meal. They leave without the honey, poor things; but the plant has attained its end, for each insect carries away, unintentionally, a good supply of pollen. Forgetting the flower's deceit, or hoping that the next flower might be more honest, the still-hungry guest calls immediately upon another blossom that has its glistening lure. 


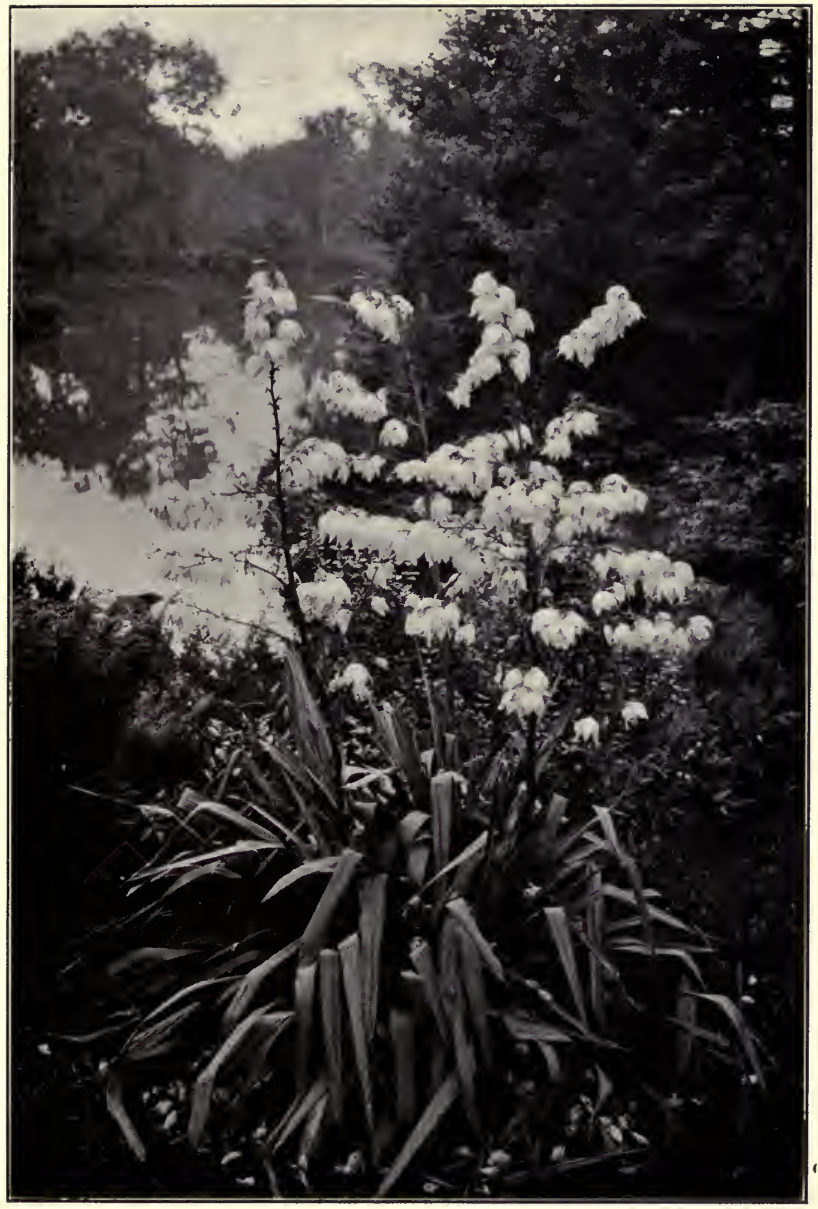

YUCCA. Yucca filamentosa.

A plant which entertains both systematically and profitably. 


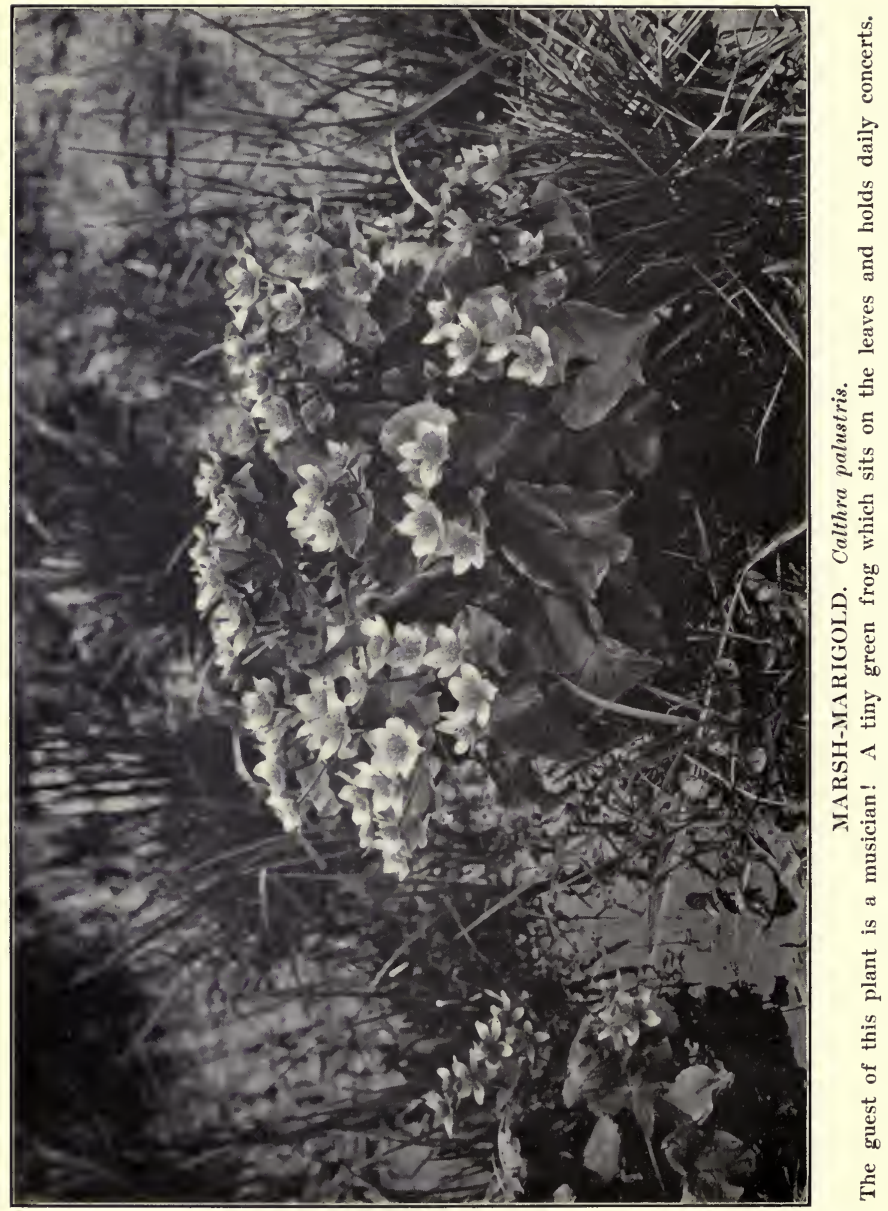


While he is being undeceived, the stigma manages to get from him a sufficient amount of pollen, and the waiting anthers shower him with a fresh supply.

Among plant-hostesses perhaps none has a more unique guest than the marsh-marigold, often known as the American cowslip. The marsh-marigold is not a true marigold, nor is it a real cowslip; but these are the common names for this early spring flower with its striking yellow varnish and its fat stalk-a favourite among the flies and insects.

Its beauty is unrivalled among the early yellow flowers; but that is not its only claim to notice. It also entertains. And its guest is a musician! This mite of a musician is a tiny green frog, which sits on the leaf of the marigold. $\mathrm{He}$ is small-not more than three-fourths of an inch long-but his voice is marvellously shrill. His concert hour is four o'clock in the afternoon. He is not always punctual; but generally at about this hour he may be seen creeping along the leaves of the marigold -his name is "Spring-creeper"-and occasionally stopping to sing in his high tenor voice, with its shrill tone in $\mathrm{E}$ flat of the highest octave on the piano.

Why the plant entertains this tiny frog, no one knows. Perhaps for the same reason that people 


\section{THE HUMAN SIDE OF PLANTS}

keep canary birds! Or perhaps he is the greenuniformed guard who defends the marigold's pollen stores from creeping insects! Certainly the plant does her duty as hostess in providing him with a dainty chamber and a choice supply of food in the form of tiny gnats and other insects which she lures to her yellow palace.

This is one of the most unique of the many instances in which plants act as hostesses. One can understand, and commend, the wisdom of those plants which entertain for purposes of material gain, or for services rendered; but some plants are seemingly extravagant enough to give of their hospitality purely for the entertainment which the guest affords his hostess! 


\section{XVIII}

PLANTS THAT GO TO SLEEP

DANTS require their sleep no less than do
animals or people. What a fantastic fairyland is a garden at night! Here we find many sleepy heads all so quiet and drooping that one wonders whether strange dreams may be forming in their plant minds. Perhaps they are!) Some flowers, like the evening-primrose, the datura, the night-blooming cereus, and the moonflower, are open only at night. What a contrast between these wide-awake faces and the numerous sleepy ones! The leaves of the acacia, the lupin, and the clover, are so tightly closed that one is reminded of the wings of butterflies folded together. Perhaps they are giving a "fairy-bed" to some poor, way-faring bee or moth! Look at the nodding nasturtiums bending their leaves as they bid us walk lightly lest we disturb their slumber!

The sleep of plants is not the least interesting of the habits of these remarkably human-like things. The leaves of a plant such as the clover, formed of 


\section{THE HUMAN SIDE OF PLAN'TS}

a number of leaflets, will fold up not only in the night but even in the daytime if the light becomes too strong.

Plants usually have certain times for sleeping; but, like people, this is mostly habit with them and they may be made to change their sleeping hours by artificial darkness or light. With the exception of the night-bloomers, which, like the owl and other night birds, have their own reason for preferring darkness, most plants like to be awake in the daylight, and to go to sleep only when the sun has gone and darkness has settled down and their own special bee-friends are dozing away with folded wings to await the dawn.

But plants, like chickens, may be fooled by artificial darkness. It has been observed that often during an eclipse of the sun, certain plants, like the pheasant's-eye, would mistake the darkness for that of night and rapidly close their flowers and leaves in sleep.

Some most interesting experiments have been made with a sensitive-plant, mimosa. At night its sleep was disturbed by the presence of a bright light, and during the day it was placed in a darkened room. As a result the plant was much troubled; it acted like a disturbed bird or animal. It opened and closed irregularly for some time, but 


\section{PLANTS THAT GO TO SLEEP 159}

finally submitted to its unnatural method of living, and, like some people, "turned night into day."

Single plants, when observed at night, do not present the sleeping appearance so strikingly as when grouped together in beds. Professor Lindley says: "Plants of corn, in which there is very little indication of sleep when growing singly, exhibit this phenomenon very distinctly when observed in masses; their leaves becoming flaccid, and their ears drooping at night."

This regular sleeping and waking of plants has occupied the attention of such distinguished men as Linnæus and Darwin; Chaucer and Shakespeare have spoken of it; and it has been observed by many others. Linnæus was led into making a series of investigations through a peculiar circumstance which Ann Pratt has interestingly described:

"A friend had sent him some seeds of a species of lotus. The red flowers which sprung from them excited his admiration, and as his gardener was absent when they came in bloom, Linnæus, immediately upon his return, took him to the greenhouse to see this new floral treasure. It was evening, and with a lantern they proceeded to the spot; but what was the surprise and vexation of Linnæus at finding that his beautiful blossoms had quite disappeared! He concluded that they had been 


\section{THE HUMAN SIDE OF PLAN'TS}

eaten by insects; but on returning the next morning to his greenhouse, he saw them in their full beauty upon the same part of the plant on which he had left them the preceding day. Again in the evening he accompanied his gardener to visit the plants, and again the flowers were gone, while the next morning once more exhibited them in full glory. His gardener declared that his master must have been mistaken, and that these could not be the same flowers, but must be fresh blossoms. Linnæus was too much of a philosopher to be satisfied with such an idle conclusion, and in the evening he examined the plant, carefully taking it up leaf by leaf, until he discovered that the blossoms had been quite hidden by the drooping foliage. This lotus is a butterfly-shaped flower; and he found, upon looking farther, that the lupins, the garden acacias, peas, and many more flowers similarly shaped, were affected in nearly the same way by the influence of night."

However, plants fold their leaves and flowers for other causes than darkness. The opening and closing of certain flowers is not influenced to any large extent by light and darkness, as they wake and sleep irrespective of the sun. This habit of sleeping at different times of the day is one of the strangest things in regard to the sleeping habits of plants. 


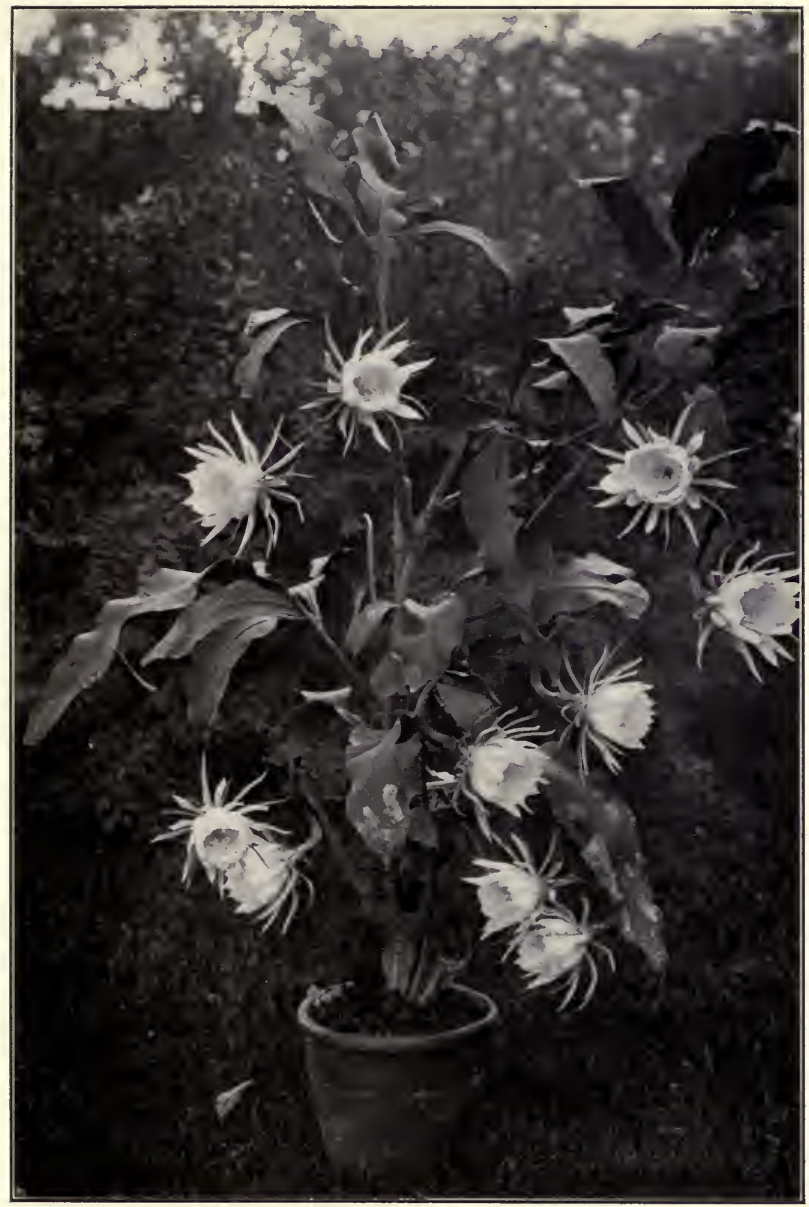

NIGHT-BLOOMING CEREUS. Cereus grandiflorus.

Having slept all day, the flowers open at nightfall, and by their powerful perfume attract insects from far and near. 


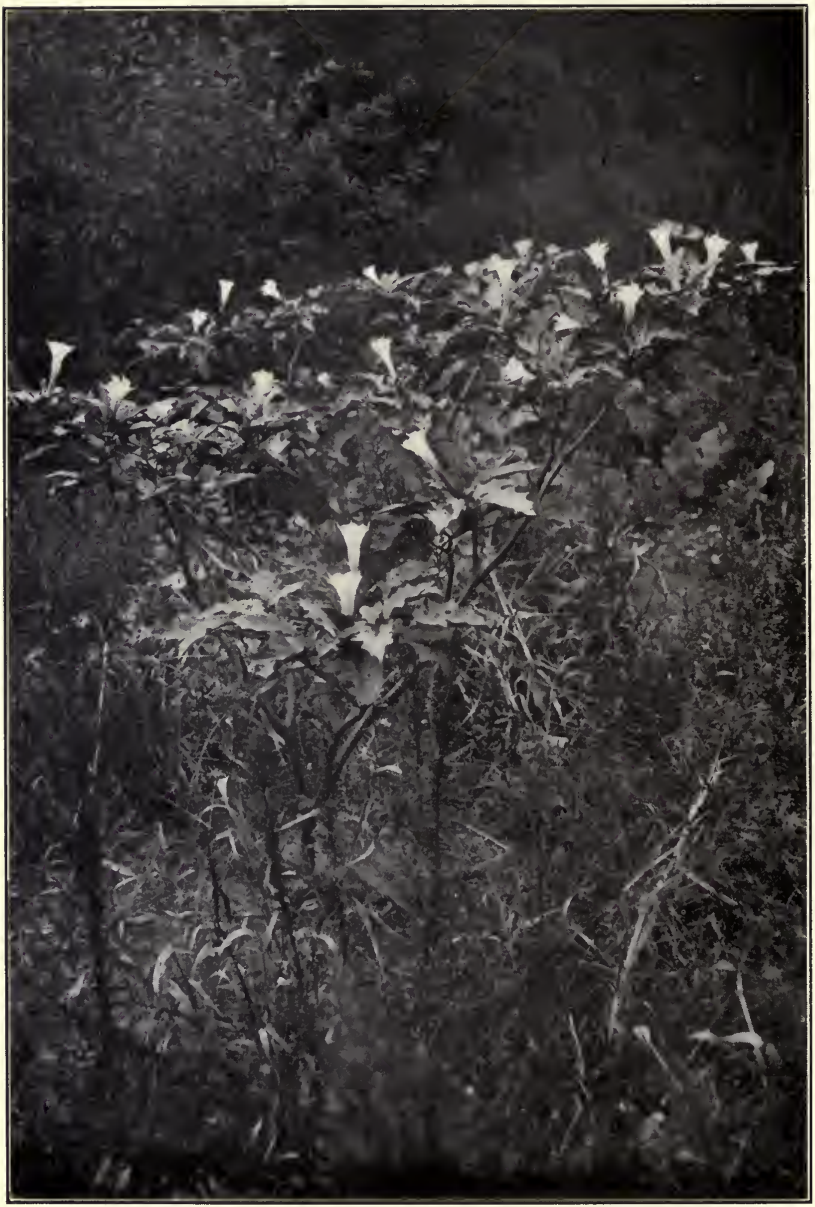

JIMSON-WEED. Datura Stramonium.

It is difficult to get a photograph of these blossoms because they open only at night-time. When morning approaches they close up in sleep. 


\section{PLANTS THAT GO TO SLEEP 161}

The goat's-beard, sometimes known as "Go-to-bedat-noon," is so named on acount of its strange custom of closing at that hour. The crocus often closes up by noontime; and the oxalis will fall to sleep, like a tired child, at various times of the day, especially if the sun is shining on it; while other plants, like the moonflower, the datura, and the night-blooming cereus, sleep practically throughout the entire day and come forth at night in all their beauty!

These habits of opening and closing at different times of the day and night are not only a protection against cold and heat, but also an assurance that the plant will be ready to receive its welcome guest, the pollen-bearing insect, whether he be a toiler of the night or of the day; for instance, the datura is visited only by insects of the night, and if, for any reason, it opened its blossoms in the day, it would possibly be neglected, and its flowers left unfertilised.

But plants require not only their daily sleep and rest; they must have longer periods of undisturbed quietude; in other words, they require vacations. So plants hibernate, just as the chipmunk, the clever arctic fox, and the arctic bear hibernate when the cold weather approaches. And they are quite as cunning and ingenious in providing for themselves 


\section{THE HUMAN SIDE OF PLANTS}

as were those clever arctic foxes spoken of by the Danish travellers as being particularly fond of the eider-duck's eggs and having to devise the trick of reaching the almost inaccessible nests where they are located on the steep sides of high cliffs, by taking one another's tails in their mouths, and thus forming a string, similar to a "human chain," of sufficient length to reach the eggs, and then letting one end down over the cliff. We are not told, however, how these eggs were passed up by the crafty foxes!

Plants are no less capable in acquiring their necessities, though much of their cleverness is hidden from us. It is well known, however, that when they hibernate they suspend practically all natural functions, and the long sleep is broken only by the approach of spring. This period of slumber is the time when the plant is inwardly preparing for the oncoming season.

But this sleep is not for long. When the snow disappears, note the marvellous change! It is almost a re-creative awakening. Even when there may be still many days of cold and frost ahead, those trees whose habit it is to flower early begin to put forth their first young buds. But should a mild period occur in December, there are no signs of awakening in these trees. Either, it seems, the 


\section{PLANTS THAT GO TO SLEEP 163}

trees are not yet sufficiently rested to arouse themselves to a new season of work; or waking, they realise that it is but an imitation of spring. Can they then tell the difference between time and time?

Warmer temperature alone does not make plants awake. Take the instance of the snowdrop: In the bulb of the snowdrop are the rudiments of its flowers and leaves; force the bloom of the plant, by means of artificial heat, in December, and the result is a weak, sickly flower: the plant has not had sufficient sleep to regain the strength spent during the preceding season. But leave the snowdrop to slumber on, as is its habit; in January or February, whether the temperature be mild or just above the freezing-point, the plant is rested, and the fresh flowers appear!

Plants seem to understand just when it is necessary for them to close up and take a vacation. Those which live in ponds dry up and sink to the bottom of the water for rest; those on the hot, dry deserts fold their arms and go to sleep, like the Rose of Jericho; but all of these, with a seeming appreciation of periods of time, are ready to come forth when the season is ready for them and when their plant-instinct tells them that outside conditions will permit them to bloom with safety.

All seeds, bulbs, and tubers, as well as growing 


\section{THE HUMAN SIDE OF PLANTS}

plants, require sleep before they grow and blossom. And the more highly developed the plant, the more sleep it requires before coming forth. The small shrub does not need as much rest as the giant trees of the California forests. Think of the tremendous amount of work to supply food materials to the millions of delicate leaves of the upper branches of a gigantic redwood, towering over three hundred feet in the air! Even the evergreens, such as the pines and cedars, which seem to work all the year round, have their times for rest and recuperation.

In this habit of vacational rests and regular sleep, plant life shows but another of its human traits. From the most lowly to the most mighty, all plants wake and slumber, slumber and wake, with methodical regularity, in response to the demands of nature. 


\section{XIX}

PLANTS THAT HIDE THEIR BLOSSOMS AND THEIR FRUIT UNDERGROUND

NATURE has many ways and means of caring her the humblest are as important as the more favoured. A very large percentage of plants reproduce by means of seeds; and there are almost as many ways of distribution as there are kinds of seeds: some roll, tumble, hop, dance, fly, swim, or crawl; others jump, dive, canoe, skate, or shoot; again, others prefer riding on animals and human beings!

But practically all of these are plants that have their fruits and flowers above ground. There are, however, some plants which are far too wise to risk exposing all their flowers or fruit above the earth, so they secretly hide at least part of their flowers, and all of their fruit, under the soil.

One of the commonest of these is the well-known peanut, or groundnut. This interesting, cloverlike plant belongs to the bean family, Leguminosæ; 


\section{THE HUMAN SIDE OF PLANTS}

it is a native of America, and is extensively cultivated in the southern and southeastern United States and in many parts of the Old World, to which it has been introduced. Its bean-like fruits not only are edible but are deliciously flavoured and very nutritious. Being rich in fat, they produce large quantities of oil. This oil is used for adulterating olive oil, for making soap, for lubricating, and for various other purposes.

The leaves of the peanut are arranged similarly to those of clover, except that there are four in a group instead of three. The blossoms are a dainty yellow, in shape not unlike the sweet-pea. When they have withered and fallen off, the stalk which held the flower bends its head down to the ground and pokes its nose into the earth to a depth of three or four inches. There, well protected from outside marauders, the seed pods develop. In this way the plant escapes many enemies common to other plants, yet unfortunately it has its own enemies among such animals as hogs and ground-moles.

The peanut has a near relative, the wild bean, or hog-peanut, whose blossoms are purple, and grow in clusters. The leaves are similar to the poison ivy; and the interesting thing about this plant is that it not only develops underground "peanuts," but has also a crop of small beans dangling from 


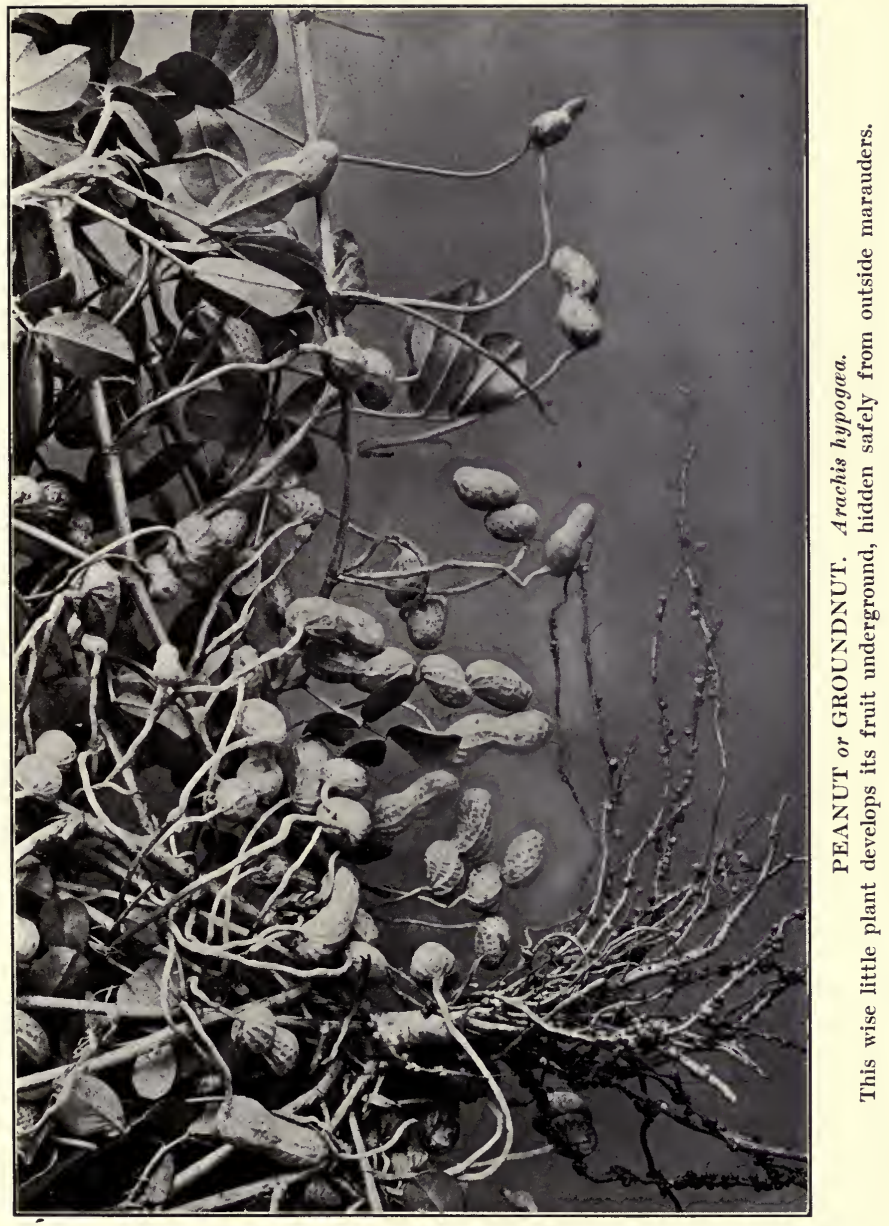




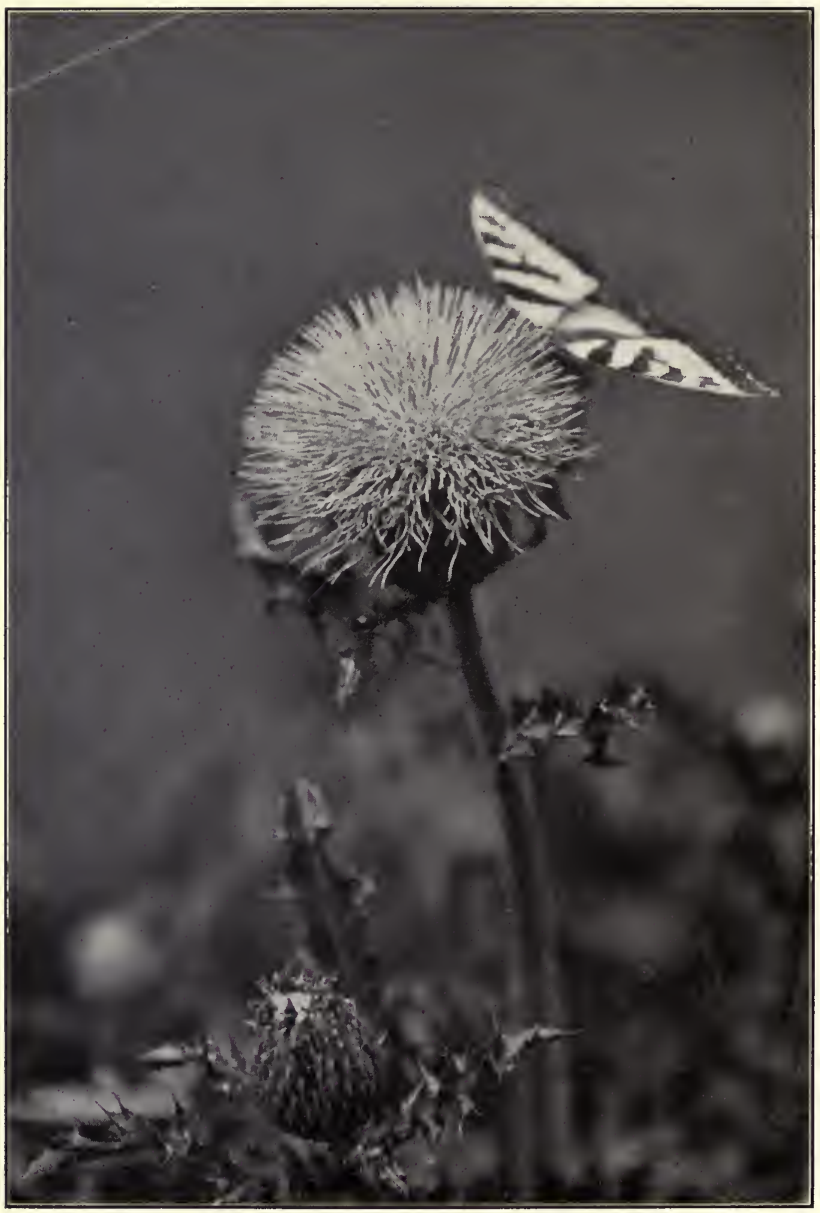

COMMON THISTLE. Cirsium lanceolatum.

The insect "go-betweens" are rewarded with a honey which is so sweet that it often intoxicates them. 


\section{PLANTS HIDE THEIR BLOSSOMS 167}

its stems above the ground. These beans act as a double insurance for the plant's perpetuation. They are grown in pods, and when the pods are ripe the seeds are hurled away, thus insuring a wide distribution; while at the same time the wise plant has stored the underground peanuts to insure the next year's crop in the immediate vicinity. These underground peanuts have been provided by unique subterranean flowers.

Still another relative of the peanut which uses this unusual method of hiding its seeds in the ground is the Voandzeia subterranea, commonly known as "the underground bean of Madagascar." This interesting plant belongs to the bean family, and is cultivated in many parts of America, and in West Africa, whence it originally came.

A few of the violets, like the sweet violet (Viola odorata), have adopted the wise plan of hiding some of their lower flowers under the earth, thus taking no undue risk of not having their seeds properly sown. These underground flowers never entirely open, yet most of them produce seeds.

The Fringed Polygala (Polygala paucifolia) flaunts above ground orchid-like blossoms of a brilliant rose-pink color; while partly or entirely under the ground it has a cluster of small, insignificantlooking flowers which never open their petals. It 


\section{THE HUMAN SIDE OF PLANTS}

is these small flowers, hidden underground, which insure the propagation of the plant. They are selffertilised, and so are not dependent upon either wind or insect for the distribution of the pollen.

The Polygala is a sociable plant, being, however, somewhat clannish, for it usually grows with a number of its own kind gathered around it.

The stem creeps underground, and perhaps this has given the Polygala its other name-flowering wintergreen-because of the creeping habit, and of the resemblance of the leaves to those of the real wintergreen. Like the wintergreen, too, it loves the deep woods, and is often found nestling at the feet of great oak trees, pines, or hickories.

Tulips, daffodils, crocuses, hyacinths, and numerous lilies, to say nothing of the common vegetables, such as potatoes, and onions, afford good examples of plants whose fruit is hidden safely underground. The onion, however, also produces seeds above ground.

Not the least interesting among the ingenious methods used by plants in hiding their seeds is that followed by certain grasses, such as the Stipa pennata, whose auger-like fruits bore themselves into the earth by a winding motion, which stops only when the seeds are well hidden underground. The cyclamen, or, as the old-time botanists called 


\section{PLANTS HIDE THEIR BLOSSOMS 169}

it, "sow-bread," is another plant which buries its seeds. When they are ripening, the flower-stalk gradually twists itself spirally toward the earth, and here it forces itself into the ground, hiding its precious seeds from the ravages of birds and animals. Some botanists believe that these seeds actually receive nourishment from the roots of the plant, as they seem to grow in no other situation.

"The wallflower, the wallflower,

How beautiful it blooms!

It gleams above the ruined tower,

Like sunlight over tombs;

It sheds a halo of repose

Around the wrecks of time-

To beauty give the flaunting rose,

The wallflower is sublime."

A most important wall-creeper, Linaria cymbalaria, hides its seeds-but not underground. This interesting wallflower, known as Kenilworth ivy, or ivy-leafed toad-flax, has a delicate fragrance making it doubly welcome as a guest on neglected walls. It grows on old, decayed, stony walls, usually where there is considerable moisture, and its small, worm-like stalks twist their tiny seed-pods into the little holes and crevices in the wall. Here, when the seeds are ripe, the pods burst open and plant them. In this way an entire wall soon becomes covered in moss-like fashion with these interesting and human-like seed-sowers, 


\section{XX}

THE COURTSHIP AND MARRIAGE OF PLANTS

$\mathrm{N}$ considering the marriage of plants it is neces1 sary to touch briefly on the physiology of plants. This, however, has been done as lightly as possible, and with as little indulgence in technical terms as could be used to give a clear understanding of their impulses and actions in their courtship and marriage, and of the dependence of plants one upon another for the reproduction of their kind.

Plants are divided into two distinct sexes, male and female. They have eyes with which they see; they have mouths with which they eat, and stomachs to digest their food. Their stomachs are in the form of leaves, nevertheless they serve the purpose. They have lungs with which they breathe; and they are capable of drinking water. The water is taken in by different mouths from those with which they take in their food. Great trees of the forest necessarily have big mouths, in the form of roots, and these mouths act as regular water-carriers which reach far into the damp ground and drink up great 


\section{THE MARRIAGE OF PLANTS 171}

quantities of water to supply the millions of leaves above.

Plants have not always had the same manner of eating, drinking, and sleeping; nor have they always had the same marriage customs as now. Just as the customs of mankind change with the passing of ages, some becoming more civilised and some less, so do plant customs change, some for a better civilisation and some, like the dodder and the Indian pipe, actually becoming degenerated.

Before the marriage takes place in the plant world there is a brief but no less real courtship! The happy and gallant wooer adorns himself gorgeously with brilliant flowers each having powdered faces calling to his love on every breeze. He must be very beautiful and charming, or she will not respond to his love by rustling her silken and perfumed leaves!

This, of course, refers to marriages among the larger and more developed plants. In most of these marriages many happy children are born in the form of seeds; and these children are well supplied by the fond mother with food and clothing before they are sent out into the big world.

Among the lower, or less developed, plants, the marriage customs are very simple and crude. In some of the water plants, like certain forms of 


\section{THE HUMAN SIDE OF PLANTS}

Algæ, there is no sex at all, and the entire plant is but a single cell. This form of plant reproduces by the simple method of cell-division: in some plants the cell divides in the middle; in others, it bursts open, producing a swarm of minute cells. In this lower form there are no organs of reproduction.

The next step in plant life is marriage between members of the intermediate or confused sex, as in certain pond-weeds. Here the plant cells are precisely alike.

But in the higher plants there are flowers, and these flowers contain the organs of reproduction. The flower is divided into various parts, including stamen and pistil or male and female. In order that the seeds may form and develop in the ovary of the pistil, the beautiful grains of yellow pollen must be brought from the stamens and showered upon the tip of the pistil-the stigma-and from there they are carried down the long style to the ovary, where they quicken the tiny ovules.

When we speak of flowers we rarely stop to consider just what the term means! It means not only the pistil, which contains the undeveloped seeds or ovules; the stamens with their pollen grains; but the petals, or, taken together, the corolla; and lastly the calyx-all these different parts combine to form the flower. The brilliantly col- 
oured petals are really used as advertisements. The reds, yellows, oranges, greens, purples, and whites, are flags that signal to the bees and butterflies to come and feast on the honey-and thus to fill their fuzzy backs with the pollen grains which will readily cling to the sticky pistil of the next flower they visit.

One of the most brilliant displays of colour is that of the flame azalea. It flaunts its gaudy blossoms over the mountain-sides, beckoning to the pollenbearers to come and taste of its honey. Its flamecoloured flowers are produced in great profusion, and, massed together, their blazing splendour gives the impression of the woods on fire. The azalea, because of its gay blossoms, is becoming very popular as a cultivated shrub.

Some plants do not care to have their pollen distributed, but fertilise their own flowers by dropping the pollen grains upon their own pistils. But in all such cases their children are degenerates, and only plants which are very low and unsuccessful in life use this means of fertilisation. While in a very large percentage of flowering plants, the male and female elements both are present in the same flower, if good healthy offspring are to be produced it is necessary for pollen to be brought from another plant, or another flower of the same plant. 


\section{THE HUMAN SIDE OF PLAN'TS}

It was long ago proved that close interbreeding produces degenerates in the plant kingdom. There are very few instances among high-class plants where perfect seeds have been produced without the ovules having been fertilised in the regular way: that is, by the transference of pollen from the male to the female flower.

Among such plants as begonias, cucumbers, gourds, squashes, there are many flowers that are distinctly either male or female. If for any reason the proper insects do not exist in the territory where such flowers are to be raised, the flowers may be fertilised by carrying pollen dust from the male to the female by means of a feather or a dainty brush. But it is far more interesting to see the bees and butterflies happy in their work of distributing pollen from flower to flower, yellow with the precious dust on their backs and heads!

Plants have various schemes for securing a crossfertilisation of their flowers. Some use the wind as an agent, others employ bees, butterflies, moths, snails, or even birds. Bird-pollination is a common occurrence in Brazil, where the profusely growing abutilon is fertilised by humming-birds. The Brugmansia and other flowers are fertilised in the same way.

Flowers use their marvellous beauty, perfume, 


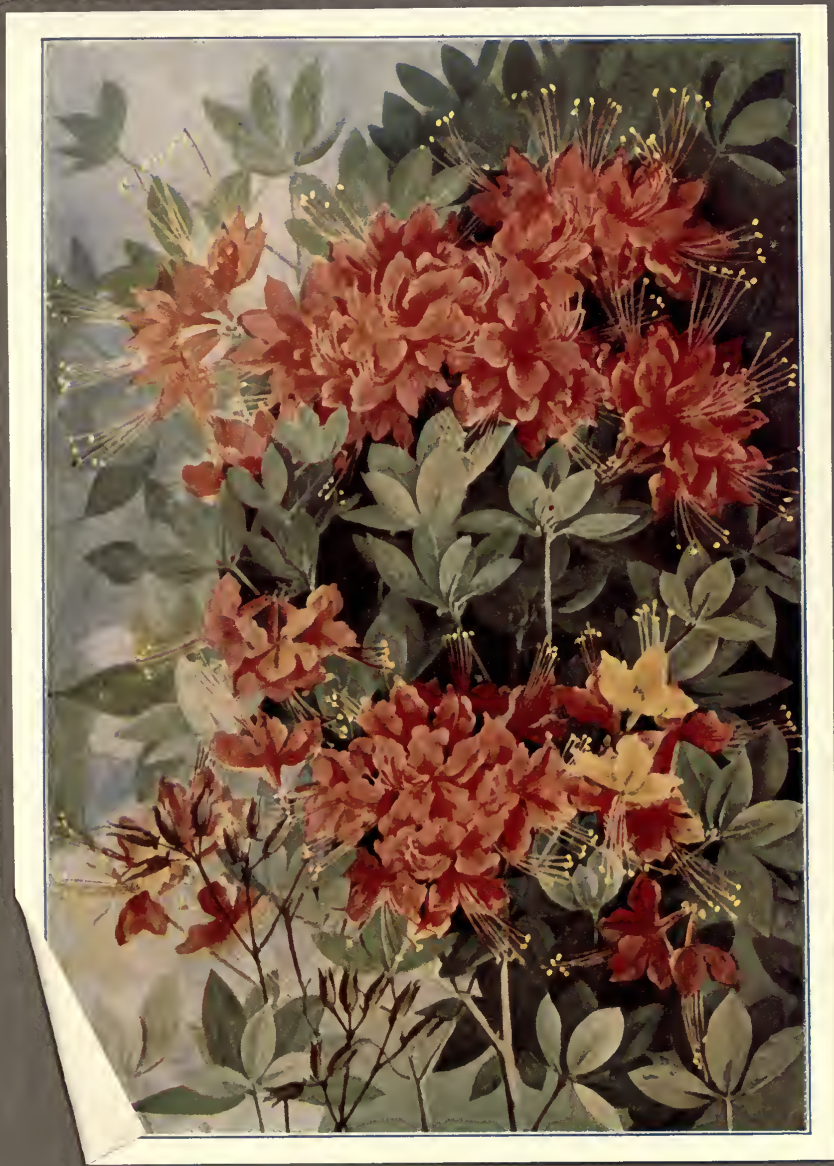

FI.AME AZ.1LE.A. Azalen lutea.

The brilliant blossoms are used as advertisements to flare in the faces of the bees and butterflies, bidding them come and partake of the nectar. 


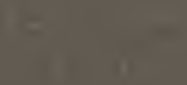




\section{THE MARRIAGE OF PLANTS}

and conspicuousness to attract to themselves insects that will distribute their pollen.

Who can look at a meadow on a summer's day and doubt that butterflies and bees are attracted by the beauty and perfume of the flowers! Evidently they enjoy the perfume as much as we; and egoistic man should learn to know that beauty was not made for him alone, but for even the tiniest creature that exists.

Dr. Asa Gray has long since called attention to and minutely described the physiology of the fertilisation of flowers. It is a subject that has required volumes of description; too deep and wide a subject to be more than scanned here. Only a few of the unusual cases of plant courtship and marriage will be mentioned.

There are numerous orchids, like the $A$ ngraecum of Madagascar, that can be fertilised only by a large moth. This moth has a proboscis ten to fourteen inches long, and is very rare. The insect always lands on the labellum of an orchid; and while many orchids have no honey to give their guests, their juicy tissue is a dainty offering to many flies and other insects.

Perhaps one of the strangest and most interesting methods of securing cross-fertilisation is that used by certain water plants which have their flower- 


\section{THE HUMAN SIDE OF PLANTS}

stalks entirely hidden under the water. The Italian eel-grass (Vallisneria spiralis) uses this unique method of fertilisation. The female flowers grow on long, spirally twisted stalks, and each flower is enclosed in a small bladder. The male flowers grow in bunches, and each entire bunch is covered with a thin skin-like sheath. The female flower has continued to reach up her head until the flowers rest on the surface of the water; while the male is tied down below by a short stalk.

Now the miracle happens! The gallant wooer deliberately breaks loose from his underwater position, and arises to the top where his lady-love is peacefully floating! The male flower bursts open his sepals and forms a tiny raft, and, by means of this raft, he is enabled to float around until some kind wind or wave brings him in contact with his love. Some of the pollen from the male adheres to the female flower; she drops to the bottom of the water, and there remains while the seeds are being developed.

There are many flowers that cater neither to birds, insects, nor water, but look only to the wind for fertilisation. These wind-fertilised flowers usually are not conspicuous; for example, there are many of the grasses, to say nothing of the large trees. Exceptions are found in quack-grass, 
Phaleris, and, among the trees, in the beautiful red flowers of the larch. With plants that have inconspicuous flowers, there is a compensation in the form of grace and elegance; for what can be more pleasing to the eye than the grace of slender grassblades!

A large part of the grasses are found on prairies and open plains, where the wind is always present to distribute their pollen. These flowers usually are delicately attached to the plants in the form of tiny spikes or swaying panicles, and the least breeze will hurl their precious gold-dust into the air. Many scientists believe that grasses are only degenerate lilies.

There are multitudes of interesting and extraordinary instances of both courtship and marriage among plants. And in considering this plant courtship and marriage there is one point which needs especial emphasis - a point which must necessarily be reiterated time and again in the consideration of the human side of plants. It is the existence of some guiding force, too impulsive to be mechanical, too versatile and efficient to be instinctive, which controls the actions and manners of plants in all the stages of their reproductive functions. There is an almost human sagacity in these actions: in the display of brilliant colours and soft perfumes to 


\section{THE HUMAN SIDE OF PLANTS}

attract their lovers; in the cunning which they show in imprisoning a bee if he should arrive before the pollen grains are ready to be sifted on his back, and of holding him, sometimes for days at a time, until he can go forth laden with the pollen that is to adhere to a pistil and so find its way to the ovary and perform the great miracle that results in seeds; in the many similar tricks which they use to entice and to hold; all working together towards that one great aim of plant life-reproduction. 


\section{XXI}

\section{PLANT-ANIMALS AND ANIMAL-PLANTS}

nitely with which of the kingdoms, animal or vegetable, certain peculiar plant-animals or animalplants should be classed. Many forms of the vegetable kingdom have so skillfully simulated the colour, shape, and various habits of certain plant-animals as to have themselves classed as animals. No one but a skilled botanist, when observing some of these darting around in the water, could doubt that he was seeing a tiny animal.

There goes the fantastical, weird Euglena viridis, with its exquisite, pale-green body, with lace-like draperies forming the delicate neck, and with its pink eye looking for all the world like that of a gold-fish-now floating nymph-like through the water, now diving toward a rock at the bottom, and now leisurely opening out its shawl-like arms! How like an animal it is! Yet this is not an animal, but a real plant. 


\section{THE HUMAN SIDE OF PLANTS}

On the other hand, there are numerous tiny animals found in ponds, lakes, and rivers, and near rocky cliffs in the oceans, whose very bodies simulate in every respect the most delicately tinted flowers, or even a handful of jewels; yet, with all these apparently inconsistent qualities, these wonderful, flower-like beings belong unquestionably to the animal kingdom.

It is practically impossible to make a distinction between the two kingdoms. There are no hard and fast lines in nature. In defining the limits between these two kingdoms, scientists in dealing with the lower forms of life have made many errors; and as a result a number of the lower forms of both animal and vegetable life have, at different periods of their existence, been classed as both plants and animals.

Even at this advanced age animals, such as the Sertularia, are gathered and preserved as seamosses! Of course, this is done only by people who are unaware that these leaf-like animals are really not plants.

In 1850 all bacteria were assigned to the vegetable kingdom, but now they are fully recognised as members of the animal kingdom. Of course one knows that a lily is a plant, and that a squirrel is an animal; but in the lower forms of life it is 
not easy to draw a dividing line between the two kingdoms. It proved too great a problem for the scientists of the past; and even to-day there is a confusion and wrangling and differing of opinions as to where the line may be drawn.

Moss-animals, which are plant-animals, reproduce in two ways: one is by sprouting new buds, the other by laying eggs. The corals all belong to the plant-animal family. Notwithstanding their striking similarity to plants in colour, shape, form, and even in reproduction by budding, they are animals, and also reproduce by laying eggs. There is one way, however, in which many moss-animals differ from the corals: that is in their form. Like the snail and the oyster, the body of the mossanimal consists of only a tiny sack containing a stomach; whereas the coral, if examined closely, shows a number of minute folders, or plates, all pointing from the edge to the centre, somewhat resembling the spikes of an umbrella. It, therefore, belongs to the jelly-fish family. Thus, while having these budding qualities, and grouping themselves into plant-like colonies, the corals are really members of the animal family.

Among the Algæ are numerous plants, brilliantly coloured: here are purples and blues, there are greens and oranges, yonder a bit of violet, yel- 


\section{THE HUMAN SIDE OF PLANTS}

low, or red. It is these forms that make "red snow" and "blood rain." Water is frequently coloured by numerous shades. For this reasonbecause of the red algæ found in its waters-the Red Sea was so named. History has many times mentioned strangely coloured rains; the Bible also speaks of such phenomena.

The Algæ belong to the vegetable kingdom, but are considered among the lowest forms of plant life. Next above them are certain forms of fungi, such as the water-moulds and the mildews. The fungi are believed to have originated as algæ; and although they are decidedly plants, they have many characteristics of animals.

"There is nothing on the land that is not in the sea!" That is well illustrated by an "animalgarden"-or gardens, for there are many of them in tropical and warm waters. These gardens are among the world's wonders of beauty. They are 'composed entirely of animals; yet the marvellously coloured beings simulate perfectly the forms and shapes of flowers. They cling to the rocks like trailing mosses, feathers, flower-like bells, and vines; some appear like daisies, geraniums, anemones; others are like roses, verbenas, begonias, or waving grasses; all are like a happy family of 
plants, growing harmoniously together in a garden, well tended by a skilled gardener.

But do not try to pick them or disturb them in any way! They are animals, and somewhere are their elfish eyes peering directly at you with uncanny meaning. Should you move, they are prepared to defend themselves. Like many plants of the earth, they have peculiar methods of defence. Some sting, others twine and coil about their enemies, actually poisoning them; and the horrible Sea Rose sends forth delicate streamers filled with semi-paralysing fluid. Some of these marvellous plant-animals have countless numbers of defensive filaments!

Even during the past century these strange creatures were so generally supposed to be flowers that the French Academy of Sciences withheld the name of Peysonnell, when he made the statement that they were animals. Like all exponents of new ideas, Peysonnell was ridiculed and his idea scorned at first by those who later were forced to herald him as a discoverer and a scientist.

Plants, like animals, have developed marvellous instincts in the choice of foods. The food of the plant evidently is chosen with as much foresight as is that of the animal or even the human being. Plants unquestionably have their likes and dislikes: 


\section{THE HUMAN SIDE OF PLANTS}

some even refuse to grow except under food conditions which they enjoy. This is another evidence of the likeness between the plant and the animal worlds; but it is more than this. In showing a taste in the selection of its food, plant life has again portrayed its striking similarity to the nature of human kind. 


\section{XXII}

THE MENTALITY AND SPIRITUALITY OF PLANTS

\section{And 'tis my faith that every flower Enjoys the air it breathes!}

-WORDSWORTH.

T the preceding chapters numerous characteris1 tics of members of the plant kingdom have been considered in comparison with similar characteristics of the human kingdom. It has been shown that plants eat and drink, sleep and wake, climb, walk, run, swim, fish, hunt, and set traps; that they see, hear, feel, taste, and smell; that they keep and pay servants, own slaves, and employ many kinds of fighting forces; that they have their courtships and marriages, and systematically reproduce their kind; that they have strong parental instincts, and care and provide for their children; that they have developed to a science the arts of bribery, mimicry, and trickery; that they carry on a continual exchange and barter, and work according to business contracts; and, finally, that they leave behind them 


\section{THE HUMAN SIDE OF PLANTS}

records of their achievements for the benefit of future generations.

In truth, it has been shown that for nearly all the characteristic traits and powers of human kind, there are corresponding traits and powers in plant life-some of which compare favourably with the human race; some far excel it; and some are inferior in their development.

But there are two characteristics of the human being, the two most distinctive qualities of human nature, which one would hardly associate with the nature of plants. These qualities are mentality and spirituality.

That very human powers of sensation and instinct are natural to plants has been shown repeatedly; therefore, in discussing plant mentality, these powers will not be referred to, but only that mentality which realises, reasons, and wills. It is positively known that plants do have both an active, existing mentality and a very evident spiritual nature.

Consider first the evidences of plant mentality. Great and unbiassed minds have for many years been centred on the study of plant habits, in the hope of finding some conclusive evidence of an existing mentality in plant life. As a result of these exhaustive investigations, occasional articles 


\section{MENTALITY AND SPIRITUALITY 187}

and treatises have appeared, which claimed that their authors had found, beyond all question, the proof of an active intelligence in plants. However, the mind of the average human is a stolid thing, and hates to be jolted from its regular course by the entertainment of new and original ideas; so it has glanced at these amusing announcements of facts and with smiling superiority has returned to its old, wormy books and theories, in calm selfsatisfaction. But the men who have furnished this amusement, who have learned really to know plant nature, smile in their turn and proclaim the truths, which their investigation is giving them.

Perhaps one of the most convincing evidences of mentality in plants is the almost invariable conversion to this belief of those who have really given themselves to study and to a sincere attempt to understand the nature of plants. Among the foremost naturalists and psychologists of the past and present stand many who are emphatic in the declaration of their belief in the theory of plant mentality and intelligence.

It is generally accepted that to animals must be given credit for some mentality. The line of demarcation between the animal and plant kingdoms has beell always a subject for dispute, and never has been established to the satisfaction of all.) Of 


\section{THE HUMAN SIDE OF PLANTS}

course the higher forms of animals can be separated easily from the higher forms of plants; but in the lower forms, there is no distinction. There are many of the lower animals which have no stomach or even a trace of a nervous system; while many of the lower plants can actually swim through the water, taking any course they desire. The most skilled scientist cannot be certain whether he is dealing with animal or plant. If, then, a dividing line cannot be drawn between the lower forms of plant and animal life, how can an intelligence be assigned to the one in its higher forms without a similar power being attributed to the other, especially when, with all other powers of the animal, the plant favourably compares?

"There is nothing unscientific," says Francis Darwin, "in classing animals and plants together from a psychological standpoint.")

In a previous chapter it has been shown that plants see and are sensitive to the presence or absence of light; that they will approach a sunny spot from the shade or a shady spot from the sun; that an approaching shadow will cause some plants to close their petals; thus proving that plants have the sense of sight.

That plants hear has been shown in the instances of those sensitive-plants which are susceptible to 


\section{MENTALITY AND SPIRITUALITY 189}

every vibration-for sound is but the effect of vibrations.

( The examples of a plant's sense of touch and of feeling are numerous. The action of the tentacles of the sundew, on being touched by a foreign substance, is evidence of this ability to feel. Plant consciousness of heat and cold frequently has been proved by approaching a flower with a hot iron; there may be no change in the light, but with the change of temperature, the flower closes, as if to protect its precious children from harm.

That plants have a sense of smell also has been proved. An odour which is offensive to a plant will cause it to close; and if endured long it may kill the plant. The wonderful power of plants to detect approaching rain, or the nearness of water, may fairly be attributed to the sense of smell; although this power might quite as fairly be attributed to a sixth sense of the plant.

The taste of plants has been proved beyond question; it is known that the taste of some plants for salt, others for sugar, iron, zinc, is very marked. There can be little question that the prevalence or scarcity of a favourite food has much to do with a plant's habitat.

The sixth sense which plants undoubtedly possess may be called the psychic sense. There are 


\section{THE HUMAN SIDE OF PLANTS}

numerous evidences of it in the plant's power to discover the presence of objects necessary to its welfare. A climbing plant, which needs a prop, will creep toward the nearest support; but should this be shifted to a spot several feet from its former position, the vine will, within a few hours, change its course to the new direction. Is it possible that the plant sees the pole? This may explain the action in this instance; but if the plant grows between two mounds or ridges, and behind the one ridge stands a wall, which will afford good climbing, but is invisible from the position of the plant, while behind the other ridge is no form of support, the plant invariably will bend its course over the ridge behind which is the wall. Examples of this may be found wherever climbing or creeping plants grow. The support is invisible from the plant's starting point; and there is no odour which, as is possible in the location of water, might give the plant some clue to the direction in which its support may be found. The only explanation seems to be the existence in the plant of a psychic sense.

There is at least one other sense which is possessed by plants to a marked degree. This may be called the physical sense. For example, most house-plants, which in their domestication have assumed more or less artificial forms, will, on being 


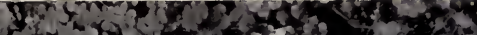

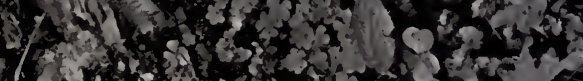

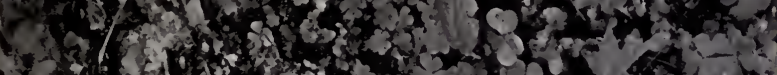

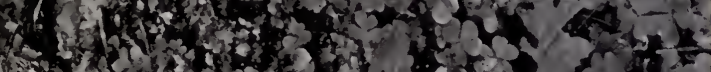

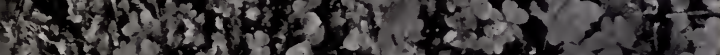

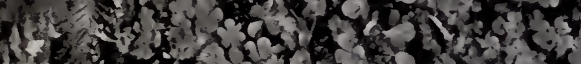

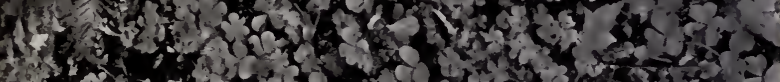

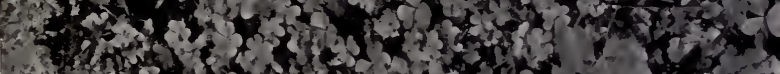

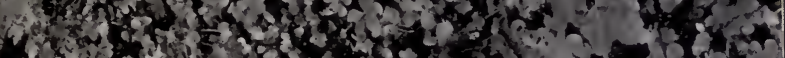

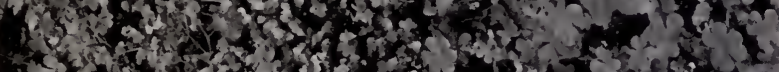

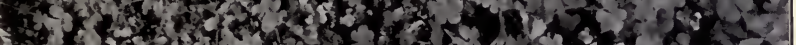

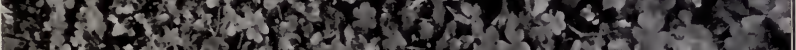

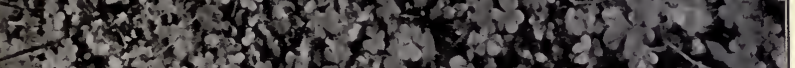

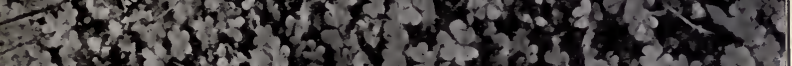

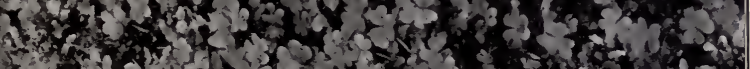

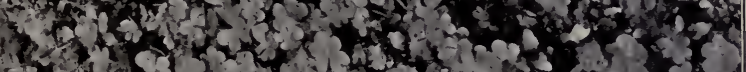

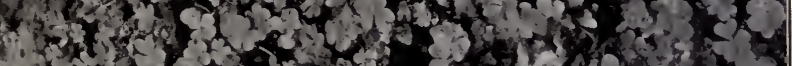

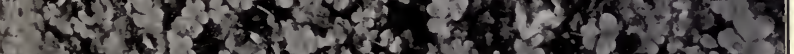

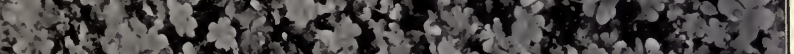

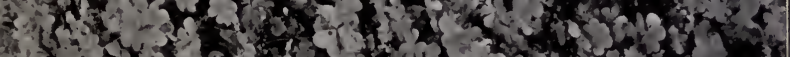

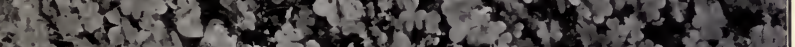

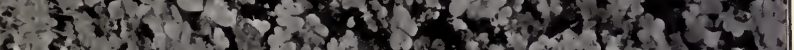

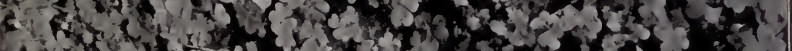

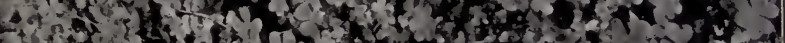

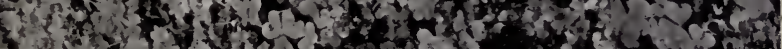

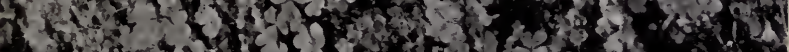

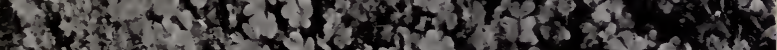

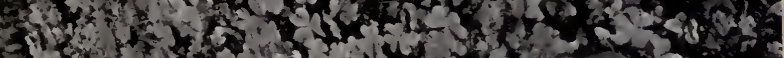

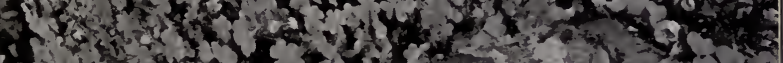

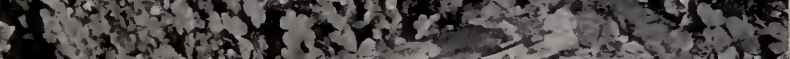

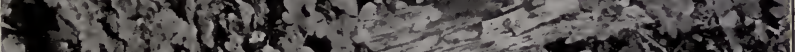

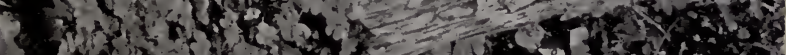

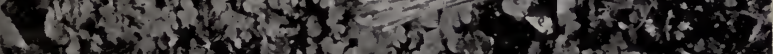
(3)

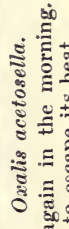

车记

돈

$\stackrel{2}{2}=$

ऊ

융

을

2

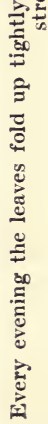




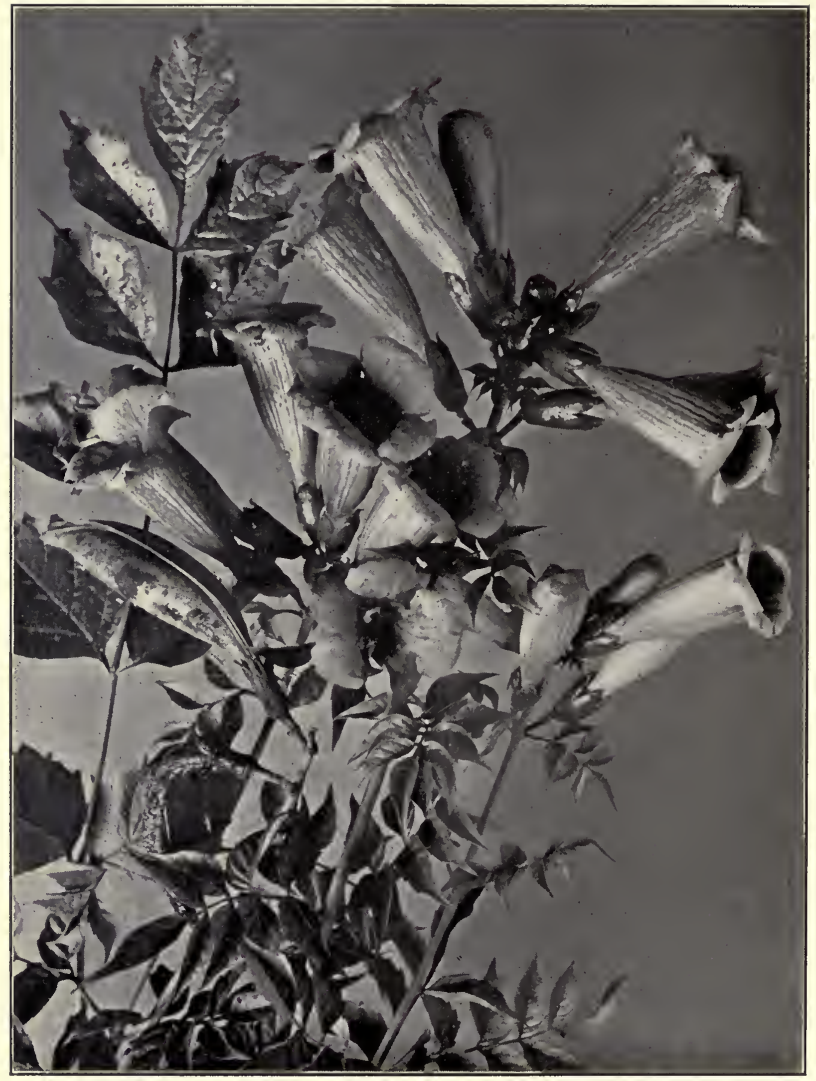

TRUMPET VINE. Tecoma radicans.

This is one of the most intelligent of all the climbing plants. Indeed, it possesses a remarkable degree of mentality. 
returned to their original haunts, reassume their natural forms. There must be in the plant some prompting sense which makes it realise any unfitness in its life or being.

An example of this may be seen by any one who will make the experiment. An oxalis, a regular "night sleeper," if subjected to strong light by night and darkness by day, at first will open and shut irregularly, as if distressed and upset by the unnaturalness of its new conditions, then gradually will assume its accustomed sleeping and waking periods, but regulating them by the darkness and light. On removing the artificial light and allowing the return of natural day and night to the flower, it will, after another period of uncertainty, return to its old habits of waking and sleeping.

These periods of uncertainty can be accounted for only by accrediting the plant with a sense of the fitness of things, a physical sense. But, granting such a sense, one comes suggestively near to granting to the plant an actual reasoning power.

Plants, then, have seven senses: sight, hearing, feeling, taste, smell, a psychic sense, and a physical sense; or six senses and a reasoning power-if the physical sense be admitted as such. These senses might be termed "passive" mentality: that is, senses which, to perform their functions, possi- 


\section{THE HUMAN SIDE OF PLANTS}

bly do not require any command of the will, but are merely natural to the plants.

If, however, these seven senses are but passive powers, and not in any way an evidence of intelligence in the plant, there are certain actual and purposeful motions of the plant which might be called its "active" mentality. It is in the existence or non-existence of this "active" mentality that we find question for consideration; plant sensation has been proved, and must be accepted as existing in the plant nature; plant action, instances of which have been shown repeatedly, cannot be explained by any theory other than that of the existence of a mentality, or reasoning power, which commands such action.

The habits of the carnivorous plants give striking examples of the existence in plant life of this power to reason, to realise, and to take action upon the realisation. Consider the insect-eating sundew. When a fly or other insect alights on the leaf of a sundew, it is immediately grasped by the tentacles which thickly cover the leaf, is flooded by a peptic fluid which exudes from glands in the leaf, and is slowly digested by the plant. But drop a tiny pebble into the tentacles. They instinctively close over it, just as the human hand, expecting to receive something, closes mechanically over an ob- 


\section{MENTALITY AND SPIRITUALITY 193}

ject, whether or not the mind of the human wants that particular object; and as the human mind would realise instantly that its hand is clasping the wrong object, so the mind of the sundew realises that this pebble is an inedible thing. It instantly opens its tentacles and allows the pebble to fall out. How does the plant know that the pebble is not a fly? Its opening its tentacles and unclasping the foreign substance is a direct voluntary action, and must be at the command of an active, reasoning mentality.

Another carnivorous plant, Venus's fly-trap, has been used frequently for a similar experiment. Its leaves will enclose anything with which it comes in contact. Even a tiny pebble, or a bit of dry wood, will be enveloped. But the plant soon detects its mistake, if it happens to catch something that is not edible, and the unwelcome substance is immediately dropped. On the other hand, if the leaf catches a fly or a bit of raw meat, it holds it tightly until all the food material is extracted. There seems no explanation for this discretionary power on the part of the plant unless the theory of plant intellect be accepted.

In their response to the reproductive and parental instincts, certain plants show a state of intellectual development which compares not unfavourably 


\section{THE HUMAN SIDE OF PLANTS}

with that of human beings. Consider those plants which open at night only, when the crawling insect pest is not about, while certain winged pollen-bearers are still at their work; there are some plants, which, being fertilised by but one kind of insect, open and emit perfume only during the hours when this insect is abroad. Consider the bribing habits of certain plants, offering sweets to the crawling insects below, and barricading, by means of numerous sharp thorns, their way to the honey and pollen nests above. Consider those flowers which, wishing to keep out falling moisture but having no wish to close their petals against the visiting bee, droop on their stems, and in their pendent position run no danger of having their pollen harmed.

These actions and habits are not merely the "natural way" of these particular plants; for the nightbloomers, kept free entirely from crawling insects, become in time day-bloomers; the plants fertilised by a particular insect, if supplied at all hours with ample fertilisation, open and emit perfume freely at other than the hours of this insect's flight; the bribers and thorn-bearers, in domestication and free from insect pests, lose their bribing sacks and their thorns; and the plants whose flowers in the wild state depended, will raise their mouths fearlessly to the sun, if protected from the rain under glass. 
"When plants find themselves in extraordinary positions, they often do things which seem to be something more than cases of cause and effect." The inherent nature of plants may account for their regular habits of living; but only some mental suggestion can account for their abandonment of the regular and their adoption of the irregular. This physical sense, the sense of the fitness of things, has its origin not in instinct but in intellect -in a reasoning power.

One of the most striking examples of reasoning action in plant life is cited by an American woman, Mrs. Treat, who proved conclusively that the leaves of the plant actually were conscious of the nearness of insects, even when there was no contact between the plant and the body of the insect. This was demonstrated by pinning a live fly half an inch from a leaf of sundew, whereupon the leaf moved itself within the succeeding two hours near enough to fasten its tentacles about the insect. Perhaps this realisation of the insect's proximity was a matter of "passive" mentality, of hearing, or seeing, or smelling, or a psychic sense; but the voluntary motion toward it cannot fairly be attributed to any source other than to a degree of reasoning power and a definite understanding of the circumstances, on the part of the plant. 


\section{THE HUMAN SIDE OF PLANTS}

In the movements of climbing plants, there are many examples of intellectual suggestion and control. The Virginia creeper, which in climbing seeks to place its tendril feet in dark cracks and crannies, is one of these. How does the plant separate dark from light, a spot where it may cling from a space that will not offer foothold, if not by some mental action, some form of reasoning?

A trumpet-vine grew in a corner of a Southern garden. Twenty-odd feet from this vine, in the centre of the garden, was an old pine stump; but the vine in the corner apparently paid no heed to its tall neighbour. One day a fire was built about the foot of the stump, and all the bark was burned from the surface, leaving the dark, smooth-charred body standing. Promptly then the trumpet-vine sent forth a long trailer, more than twenty feet across open ground, to the charred stump, up which it climbed. The parent vine formerly had divided its attention among many small shoots and trailers, but now it gave its entire attention to this single trailer, which had found a good position. And before long the whole of the blackened surface was hidden beneath the leaves and blossoms of the new vine. Was it blind instinct that sent out but one long trailer, and that one in direct line to the old, charred stump? Was it blind instinct telling the 


\section{MENTALITY AND SPIRITUALITY 197}

trumpet-vine to wait for a fire to come and burn the bark from the stump, in order to make it a convenient climbing place? Was it blind instinct that showed the plant that the distant stump with its bark on was not a secure foundation for its offspring? And was it blind instinct that, when once the stump was cleared, said to the plant, "Go! Now is the right time!" In human beings we should call that reason!

Numerous experiments have proved that seeds planted on damp sponges, which are suspended in the air, will, according to habit, send their roots downward. But they do not find nourishment in the dry air, and they immediately turn back to the damp sponge. That shows clearly their instinct of self-preservation. Whether the plant knew that there was no water below, either by seeing, or smelling, or the psychic sense, does not matter; the instinct of self-preservation warned it-that was "passive" mentality. But "active" mentality heeded the warning, guided the return, instigated the forces that produced the backward journey-just as the mind of man commands the motion of his arms, through the action of the muscle-forces. There were several distinct mental actions here: a realisation of lack of nourishment in the air, a conscious desire to return to the moist sponge above, 


\section{THE HUMAN SIDE OF PLANTS}

and a voluntary command which instigated and controlled the action of the forces that bent the root and carried it back.

The question then arises: "If there is an 'active' and a 'passive' mentality in plants, if they possess senses and instincts as well as reasoning powers, where is the seat of all these powers-where is the plant brain?"

This would be a matter of plant physiology rather than plant psychology, were it a point that could be placed under any classification; but, up to the present time, scientists have been unable to identify any specific part of a plant with this brain seat.

Spirituality is a condition of responsiveness to and membership in the universal spirit, the spirit of the Creator, the Infinite Substance, God.

The assertion that plants have spirituality, have souls, has been held up to ridicule wherever and whenever made. Nevertheless many scientists of great reputation and ability, realising that "the best part of our universe is hidden from the 'unassisted sight,' and that the 'music of the spheres' is altogether unheard by the ordinary ear," have given to the idea of plant spirituality more than a passing glance, with absolute conversion, in frequent cases, to the affirmative side of the question. 
From the earliest history down to the present day, there have been races and individuals who believed implicitly in the spirituality of plants. The old Greeks and Romans gave to the trees and plants the spirits of gods and men; and "many in more modern times have lavishly bestowed souls upon plants, as did Adamson, Bonnet, Hedwig, and Edward Smith. Martius and Fechner, in Germany, defended these views, and were very liberal in their supply of souls to plants ..." Surely there is a suggestion of some existent truth, which should cause this universal interest and investigation into the possibility of plant spirituality! (Flowers appeal to the souls of men. A very beautiful orchid or rose, the rich perfume of the lily-of-the-valley, or the soft, delicate odour of the wood violet, each has a very direct appeal to the soul of man. Of course, there is a sensuous appeal -the rose and the orchid appeal to the sight, the lily-of-the-valley and the violet to the sense of smell-but the beauty and the perfume go deeper than the senses. There is a spiritual inspiration in the fairness and sweetness which drives out the unbeautiful, the gross, and the sordid from the soul; which unlifts the spirits with deep joy, with-a delirious happiness at times, and arouses the highest and noblest impulses of men. And that which 


\section{THE HUMAN SIDE OF PLANTS}

radiates the inspiration to happiness and sweetness and goodness must be the universal spirit, the spirit of God. The inspiration from the beautiful flower must be from the spirituality of the flower, from the degree of the universal spirit in the flower.

"All life," writes Thomas Gentry, "like all love, is divine. There can nothing exist that does not contain some sort of development of soul."

In ancient literature are many instances of races worshipping and making obeisance to trees, plants, and their flowers. In this "plant worship" is one of the greatest and most important tributes to the spirituality of plants. The tree-worshipper and the flower-worshipper were but acceding to the demand from within, the desire of their souls to commune with the universal spirit, the spirit of the Creator, of God, as it appeared to them in the living plants.

And this is the appeal of the beautiful flower, the delicate plant, the soft-shaded leaf, the sighing tree. Back of the beauty and the sweetness is a deep, underlying consciousness, a spirituality of the all-permeating universal spirit, of which this beauty and this sweetness are the means of expression. The appeal is of the plant-spirituality through the senses to the soul of men; it is a commingling, a blending, of members of the universal spirit. / And here, in this membership in the universal 


\section{MENTALITY AND SPIRITUALITY 201}

spirit, is the greatest and closest tie between plants and human beings. The spirituality of the man and the spirituality of the plant, being of one. source and one existence, ineffably link together the two natures into the one great chain of life, offering to each a sympathetic perception of the other, joining both in the eternal kinship of Universal Nature. 







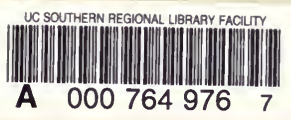


